\title{
HORTALIÇAS: CONSUMO E PREFERÊNCIAS DE ESCOLARES
}

\section{Michele SANCHES}

Dissertação apresentada à Escola Superior de Agricultura "Luiz de Queiroz", Universidade de São Paulo, para obtenção do título de Mestre em Ciência, Área de Concentração em Ciência e Tecnologia de Alimentos.

PIRACICABA

Estado de São Paulo - Brasil

Novembro - 2002 


\section{HORTALIÇAS: CONSUMO E PREFERÊNCIAS DE ESCOLARES}

\section{MiCHELE SANCHES}

Engenheiro Agrônomo

Orientadora: Profa. Dra. MARINA VIEIRA DA SILVA

Dissertação apresentada à Escola Superior de Agricultura "Luiz de Queiroz", Universidade de São Paulo, para obtenção do título de Mestre em Ciência, Área de Concentração em Ciência e Tecnologia de Alimentos.

PIRACICABA

Estado de São Paulo - Brasil

Novembro - 2002 


\section{Dados Internacionais de Catalogação na Publicação (CIP)} DIVISÃO DE BIBLIOTECA E DOCUMENTAÇÃO - ESALQ/USP

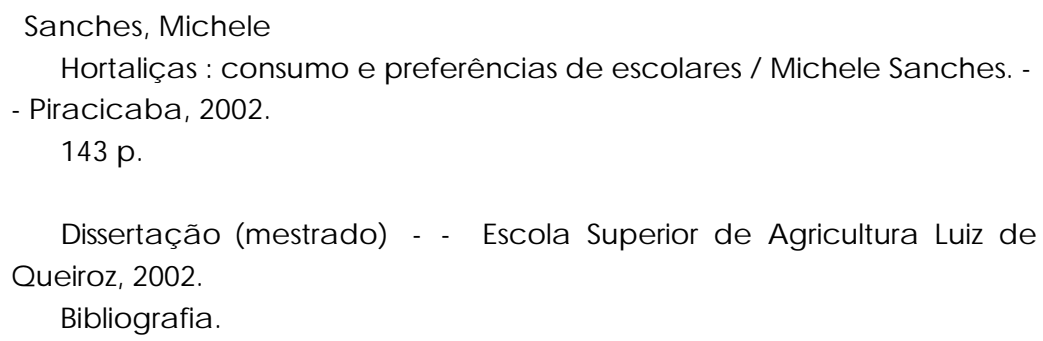

1. Alimentação escolar 2. Consumo alimentar 3. Frutas 4. HortaliçasProcessa -mento 5. Merenda esc olar 6. Progra mas de nutrição I. Título

CDD 664.8

\section{"Permitida a cópia total ou parcial deste documento, desde que citada a fonte - O autor"}




\section{Dedico esta dissetação,}

Aos maus pais, I vanil e Sebastião, palos ensinamentos, polo arer e por etarem ao meu lado, sempre, a minha etema graticão.

Às minhas imãs, I vania e Camila, polo constante incentivo e amizadeverdadera. 
Ao Marcdo, pelo auxilio, estímulo, pło anror e compreensão entodos os momentos emque estive ausente 
$\underline{=}$ 


\section{AGRADECIMENTOS}

À Profa. Dra. Marina Vieira da Silva, pela amizade, valiosa orientação e inúmeras sugestões, as quais enriqueceram o conteúdo desta pesquisa.

À Escola Superior de Agricultura "Luiz de Queiroz", pela acolhida durante a minha graduação e pós-graduação.

Aos professores, funcionários e amigos do Departamento de Agroindústria, Alimentos e Nutrição, pela amizade e carinho durante todo o desenvolvimento deste trabalho.

À minha ilustre Banca de Qualificação: Profa. Dra. Betzabeth Slater Villar, Profa. Dra. Marta Helena Fillet Spoto e Prof. Dr. Cláudio Rosa Gallo, pelas contribuições a esta dissertação.

Ao Prof. Dr. Rodolfo Hoffmann, pela excelente orientação para a realização das análises estatísticas.

À amiga Daniela Cristina Rossetto Caroba, pelo imenso auxílio, incentivo, carinho e amizade demonstrados, sempre. 
À amiga Vanessa Maestro, pela ajuda na coleta de dados, pelo incentivo e pela amizade constante.

Ao amigo Carlos Alberto, pela colaboração.

À amiga Aline Prudente, pela infinita ajuda, incentivo e amizade.

À amiga Adriana Paesman, pelo auxílio.

Às amigas Alisângela, Ana Maria, Cláudia, Elaine, Luciana e Mariana, pela preciosa amizade demonstrada, sempre.

Às Bibliotecárias Beatriz Helena Giongo e Mídian Gustinelli, pelo auxílio bibliográfico prestado.

À Diretoria de Ensino de Piracicaba e à Direção e Funcionários das escolas integrantes da pesquisa, pelo consentimento na realização deste trabalho.

A todos os escolares e familiares pela imensa colaboração na realização desta dissertação.

Ao Conselho Nacional de Desenvolvimento Científico e Tecnológico $(C N P q)$, pela concessão da bolsa.

A todos que eu não tenha mencionado e que colaboraram na realização desta pesquisa, os meus mais profundos agradecimentos. 


\section{SUMÁRIO}

Página

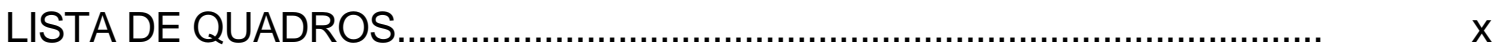

LISTA DE TABELAS.........................................................................

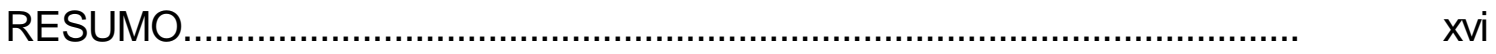

SUMMARY .......................................................................................

1 INTRODUÇÃO

2 REVISÃO DE LITERATURA .............................................................. 5

2.1 Consumo alimentar e estado nutricional............................................... 5

2.2 O programa de alimentação escolar - PAE.............................................. 16

2.3 Hortaliças minimamente processadas.................................................. 18

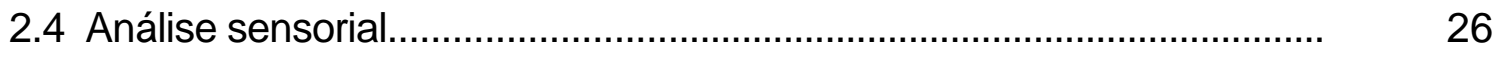

3 MATERIAL E MÉTODOS................................................................... 29

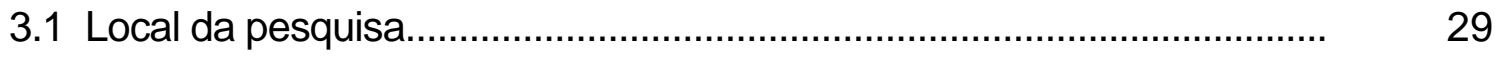

3.2 População de estudo........................................................................ 31

3.3 Obtenção e análise dos dados........................................................... 32

3.3.1 Estado nutricional........................................................................ 33

3.3.2 Consumo alimentar........................................................................... 34

3.3.3 Informações socioeconômicas da família.............................................. 37

3.4 Análise sensorial das hortaliças minimamente processadas.................... 37 


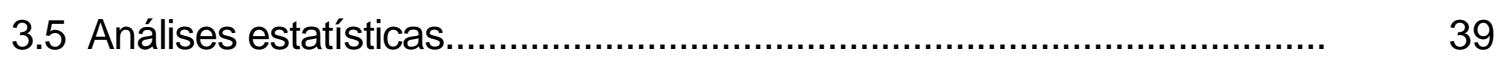

4 RESULTADOS E DISCUSSÃO.......................................................... 41

4.1 Estado nutricional....................................................................... 41

4.2 Consumo alimentar..................................................................... 53

4.2.1 Análise quantitativa....................................................................... 53

4.2.2 Análise qualitativa...................................................................... $\quad 76$

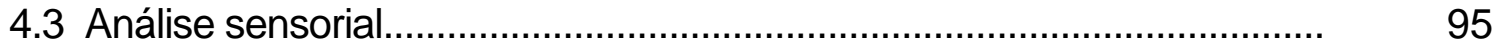

5 CONCLUSÕES............................................................................ 103

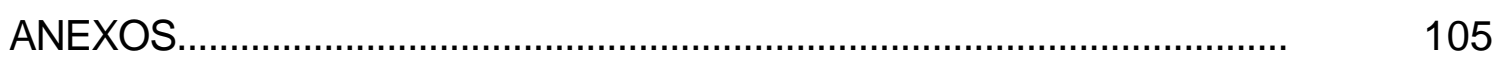

REFERÊNCIAS BIBLIOGRÁFICAS...................................................... 128 


\section{LISTA DE QUADROS}

Página

1 Recomendação de energia (kcal) para os escolares, de acordo com a idade e o gênero...............................................................

2 Indicadores socioeconômicos do município de Piracicaba, São Paulo, nos anos 1970, 1980 e 1991............................................... 


\section{LISTA DE TABELAS}

Página

1 Distribuição das escolas públicas e alunos sorteados para integrarem a amostra. Piracicaba, 2001........................................

2 Distribuição da amostra dos alunos matriculados nas unidades de ensino, de acordo com o gênero e a idade. Piracicaba, 2001..........

3 Distribuição dos escolares em categorias do estado nutricional, com base nos percentis do Índice de Massa Corporal - IMC e

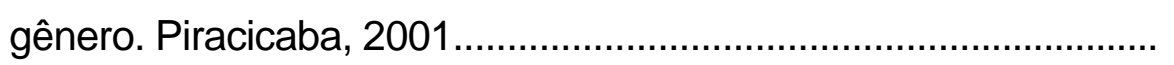

4 Distribuição dos escolares em categorias do estado nutricional com base no Índice de Massa Corporal - IMC e gênero. Piracicaba, 2001

5 Distribuição dos escolares de acordo com o estado nutricional, com base no Índice de Massa Corporal - IMC e estratos de renda familiar per capita. Piracicaba, 2001 
6 Distribuição dos escolares de acordo com o estado nutricional, com base no escore $Z$ de altura para idade - ZAl e estratos de renda familiar per capita. Piracicaba, 2001.......................................

7 Distribuição dos escolares de acordo com o estado nutricional, com base no escore $Z$ de peso para idade - ZPI e estratos de renda familiar per capita. Piracicaba, 2001.....................................

8 Distribuição dos escolares de acordo com o estado nutricional, com base no Índice de Massa Corporal - IMC e a escolaridade da mãe. Piracicaba, 2001

9 Distribuição dos escolares de acordo com o estado nutricional, com base no Índice de Massa Corporal - IMC e a atividade profissional da mãe.

10 Distribuição dos escolares de acordo com a atividade profissional da mãe e estratos de renda familiar per capita. Piracicaba, 2001....

11 Distribuição dos percentis do consumo de energia e nutrientes dos escolares. Piracicaba, 2001

12 Distribuição dos percentis do consumo de energia e nutrientes, de acordo com o gênero dos escolares. Piracicaba, 2001

13 Participação média de energia e nutrientes, provenientes do consumo de hortaliças, na dieta dos escolares, de acordo com o gênero, matriculados na rede pública de ensino de Piracicaba, 2001 
14 Participação média de energia e nutrientes, provenientes do consumo de frutas, na dieta de escolares, de acordo com o gênero, matriculados na rede pública de ensino de Piracicaba, 2001

15 Distribuição dos escolares de acordo com a participação relativa dos macronutrientes no Valor Energético Total - VET e o gênero. Piracicaba, 2001

16 Distribuição dos escolares de acordo com a participação relativa dos macronutrientes no Valor Energético Total - VET e estratos de idade. Piracicaba, 2001

17 Distribuição dos escolares de acordo com a participação relativa dos macronutrientes no Valor Energético Total - VET e os percentis do Índice de Massa Corporal - IMC. Piracicaba, 2001

18 Distribuição dos escolares de acordo com a participação relativa dos macronutrientes no Valor Energético Total - VET e estratos de renda familiar per capita. Piracicaba, 2001

19 Distribuição dos escolares de acordo com a participação relativa dos macronutrientes no Valor Energético Total - VET e escolaridade da mãe.

20 Distribuição dos escolares de acordo com a participação relativa dos macronutrientes no Valor Energético Total - VET e a atividade profissional da mãe. Piracicaba, 2001 
21 Distribuição das citações dos pais (ou responsáveis) de acordo com a freqüência de consumo de hortaliças, no domicílio da família. Piracicaba, 2001

22 Distribuição das citações relativas ao consumo de hortaliças pelas famílias dos escolares, de acordo com os estratos de renda familiar per capita. Piracicaba, 2001

23 Distribuição das citações da opinião dos pais (ou responsáveis) dos escolares, relativas à hortaliças apreciadas e consumidas pela família no domicílio. Piracicaba, 2001

24 Distribuição das citações relativas ao consumo de hortaliças pelas famílias dos escolares, de acordo com a escolaridade materna. Piracicaba, 2001

25 Distribuição das citações das preferências dos escolares, relativas às hortaliças consumidas no domicílio. Piracicaba, 2001

26 Distribuição das citações das preferências dos escolares, relativas ao consumo de hortaliças na unidade de ensino. Piracicaba, 2001

27 Distribuição das citações dos pais (ou responsáveis) com relação à expectativa do consumo de hortaliças pelos filhos, no caso das mesmas integrarem os cardápios do Programa de Merenda Escolar. Piracicaba, 2001. 
28 Distribuição dos escolares de acordo com a aceitabilidade das hortaliças minimamente processadas (cenoura e vagem) e o gênero. Piracicaba, 2001

29 Distribuição dos escolares de acordo com a aceitabilidade das hortaliças minimamente processadas e renda familiar per capita. Piracicaba, 2001

30 Participação relativa de energia e nutrientes (selecionados) provenientes das hortaliças consumidas pelos escolares da rede pública de ensino de acordo com a análise sensorial. Piracicaba, 2001

31 Participação relativa de energia e nutrientes (selecionados) provenientes das frutas consumidas pelos escolares da rede pública de ensino de acordo com a análise sensorial. Piracicaba, 2001

32 Distribuição dos escolares de acordo com a participação relativa dos macronutrientes no Valor Energético Total - VET e aceitabilidade das hortaliças minimamente processadas (cenoura e vagem). Piracicaba, 2001 


\title{
HORTALIÇAS: CONSUMO E PREFERÊNCIAS DE ESCOLARES
}

\author{
Autora: MICHELE SANCHES \\ Orientadora: Profa. Dra. MARINA VIEIRA DA SILVA
}

\section{RESUMO}

Análises elaboradas nas últimas três décadas, tendo por base dados obtidos por pesquisas nacionais revelam que houve redução do consumo, pela população brasileira, de alimentos de origem vegetal. Também tem sido destacado por diversos autores que o baixo consumo de frutas e hortaliças está associado ao maior risco do desenvolvimento de doenças cardiovasculares e diversos tipos de câncer. Pesquisas envolvendo crianças e adolescentes brasileiros revelam que os mesmos consomem, de forma geral, reduzida quantidade desses alimentos. Com o objetivo de estimular o consumo dos alimentos de origem vegetal, têm sido buscadas alternativas e, entre essas, a incorporação de maior quantidade e variedade dos referidos alimentos nas refeições dos programas alimentares dirigidos, por exemplo, aos escolares. Uma alternativa que se revela promissora é a utilização dos alimentos minimamente processados, também considerados de "conveniência" ou de "fácil preparo". A presente pesquisa, realizada no município de Piracicaba - SP e tendo por base amostra de 210 escolares, matriculados em escolas públicas, visou conhecer: a aceitabilidade das hortaliças minimamente processadas; 
a análise do consumo de alimentos, com destaque para a contribuição de energia e nutrientes provenientes das hortaliças e frutas e, também, a avaliação do estado nutricional dos alunos. Foram analisados os indicadores antropométricos (escore $Z$ de altura para idade - ZAl e escore $Z$ de peso para idade - ZPI) e a distribuição do Índice de Massa Corporal - IMC. As informações relativas ao consumo alimentar (análises quantitativas e qualitativas) foram obtidas por meio da realização de entrevistas, adotando-se o método de registro de alimentos (Recordatório 24 horas). Para o cálculo e as análises do conteúdo de energia e nutrientes presentes na alimentação dos escolares utilizou-se o software Virtual Nutri (Philippi et al., 1996). Para conhecer a opinião do grupo de alunos sobre as hortaliças minimamente processadas, realizou-se teste de análise sensorial, adotando-se a escala hedônica facial de três pontos. Os resultados revelaram que dos alunos entrevistados, $35,2 \%$ das meninas e $32,4 \%$ dos meninos apresentaram sobrepeso enquanto apenas $1,9 \%$ dos escolares revelaram condição oposta, ou seja, baixo peso. Verificou-se que $50 \%$ da população estudada possui dieta cujo conteúdo energético não atingiu o valor mínimo recomendado e, somente $36,19 \%$ dos escolares apresentaram adequada participação dos macronutrientes (carboidratos, proteínas e lipídios) no Valor Energético Total VET. Observou-se também, que $58,10 \%$ dos participantes da pesquisa gostaram muito das hortaliças minimamente processadas, e apenas $10,47 \%$ reprovaram os vegetais. verificou-se que $17,14 \%$ das meninas e apenas $3,81 \%$ dos meninos, afirmaram "não gostar" das hortaliças minimamente processadas. Ressalta-se que $61 \%$ dos escolares que revelaram "gostar muito" dos vegetais minimamente processados, pertencem a famílias com menor renda per capita. Há possibilidades que uma maior oferta e consumo de hortaliças, pelos alunos, seja assegurada com a devida incorporação de alimentos minimamente processados æ̀̀ refeições dos programas alimentares, que vigoram atualmente no Brasil. 


\title{
VEGETABLES: CONSUMPTION AND STUDENTS PREFERENCES
}

\author{
Author: MICHELE SANCHES \\ Adviser: Profa. Dra. MARINA VIEIRA DA SILVA
}

\section{SUMMARY}

\begin{abstract}
Analysis elaborated in the last three decades, based on information obtained through national researches reveal that there was reduction of the consumption, for the Brazilian population, of foods of vegetable origin. It has also been highlighted by several authors that the low consumption of fruits and vegetables is associated to a larger risk of development of cardiovascular diseases and several cancer types. Researches involving children and Brazilian teenagers reveal that they consume, in general, reduced amount of those foods. With the objective of stimulating the consumption of the foods of vegetable origin, alternatives have been looked for and, among those, the incorporation of a larger amount and variety of the referred foods in the meals of the alimentary programs driven to the scholars, for instance. An alternative, which seems promising, is the use of the minimally processed vegetables, also considered of "convenience" or "easy to prepare". This research, accomplished in the municipal district of Piracicaba - SP, based on a sample of 210 students, enrolled in public schools, aimed to know: the
\end{abstract}


acceptability of the minimally processed vegetables; analyze the consumption of foods; highlighting the contribution of energy and nutrients coming from vegetables and fruits and, also, the students' nutritional status. The anthropometrical indicators were analyzed ( $Z$ - scores of height to age - ZAl and $Z$ - scores of weight for age - ZPI) as well as the distribution of the Body Mass Index - BMI. The information concerning the alimentary consumption (quantitative and qualitative analysis) was obtained through interviews, being adopted the method of registration of foods (Reminding 24 hours). For the calculation and analysis of the content of energy and nutrients present in the students feeding it was used the software Virtual Nutri (Philippi et al., 1996). To know the opinion of the students' group on the minimally processed vegetables, a sensorial analysis took place, adopting the three points facial hedonic scale. The results revealed that, among the interviewed students, only $35,2 \%$ of the girls and $32,4 \%$ of the boys presented overweight while $1,9 \%$ of the students revealed the opposite condition, that is, low weight. It was verified that $50 \%$ of the studied population have a diet in which energy content didn't reach the recommended minimum value and, only $36,19 \%$ of the students presented appropriate participation of the macronutrients (carbohydrates, proteins and lipids) in the Total Energy Value - TEV. It was also observed that $58,10 \%$ of the participants of the research enjoyed a lot the minimally processed vegetables, and only $10,47 \%$ didn't enjoy the vegetables. It was verified that $17,14 \%$ of the girls and only $3,81 \%$ of the boys stated not to "enjoy" the minimally processed vegetables. It is important to say that $61 \%$ of the students who revealed to "enjoy a lot" the minimally processed vegetables, belong to families that have a smaller family income per capita. There are possibilities that a larger offer and consumption of vegetables, among the students, is guaranteed with the incorporation of minimally processed foods to the meals of the alimentary programs in place in Brazil today. 


\section{INTRODUÇÃO}

Segundo a Organização Mundial de Saúde - OMS, cerca de 2 bilhões de indivíduos, distribuídos em diversos países do mundo, apresentam algum tipo de deficiência nutricional. Enquanto 800 milhões de pessoas não conseguem suprir suas necessidades básicas de energia e nutrientes, contingente de 600 milhões sofre com as conseqüências de uma alimentação inadequada e desequilibrada (Junqueira \& Peetz, 2001).

Um consumo alimentar inadequado, por períodos prolongados, resulta em esgotamento das reservas orgânicas de micronutrientes, trazendo como conseqüência para crianças e adolescentes, retardo no desenvolvimento, redução na atividade física, diminuição da capacidade de aprendizagem, baixa resistência a infecções e maior suscetibilidade às doenças (Oliveira et al., 1998).

Reconhece-se que as análises envolvendo os determinantes do consumo de alimentos são complexas, especialmente quando se considera a situação da população de um país, com as características muito peculiares, como as observadas no Brasil.

Tendo por base os maiores levantamentos sobre consumo, realizados no país, nas últimas três décadas, foi possível verificar uma clara tendência à diminuição do consumo de alimentos de origem vegetal (especialmente o arroz e o feijão).

A diminuição dos vegetais na participação energética da dieta foi analisada por Mondini \& Monteiro (1994), tendo por base informações para 0 país como um todo. Os autores observaram que as frutas passaram de 3,8 para 
2,5 do percentual de energia, e o grupo composto por raízes e tubérculos revelou queda de 5,6 para 4,0 .

Enfatiza-se que, dietas ricas em vegetais têm sido associadas ao reduzido risco de desenvolver, entre outras, doenças cardiovasculares, câncer e doenças crônicas.

As pesquisas que avaliam o consumo alimentar de indivíduos em idade escolar, a exemplo dos dados obtidos junto à população adulta, têm apontado para um baixo consumo de frutas e hortaliças (Oliveira et al., 1998).

O consumo de frutas e hortaliças por crianças e adolescentes, especialmente no ambiente doméstico, geralmente reflete, em parte, o hábito da família e algumas características individuais. Estas últimas são determinadas pelas preferências inatas, pelo tipo e pela forma como os vegetais foram incorporados na pauta alimentar das crianças, durante os primeiros meses de vida (Morais et al., 1996 e Gambardella et al., 1999).

Não sobram dúvidas, para os pesquisadores, que a formação dos hábitos alimentares ocorre à medida que a criança cresce, até o momento em que conquistará independência para escolher os alimentos que integrarão a sua dieta (Fisberg et al., 2000).

Considerando que expressiva parte do tempo das crianças é dedicada as atividades escolares e, também, que substancial proporção de crianças com idade de 7 a 14 anos são atendidas diariamente nas escolas públicas, por meio do programa de alimentação escolar, é lícito reconhecer que a escola constitui-se num canal privilegiado para a promoção da formação de hábitos alimentares saudáveis (Oliveira, 1997).

Dessa forma, a escola torna-se um espaço onde se deve estimular o consumo de alimentos com elevada qualidade nutricional, uma vez que é na infância que podem ser incorporadas as práticas alimentares, difíceis de serem modificadas na idade adulta (Gouveia, 1999).

É válido considerar a importância assumida, para a população de 7 a 14 anos em todo o Brasil, do Programa Nacional de Alimentação Escolar - 
PAE, encarregado de planejar o fornecimento da merenda escolar, como recurso para interferir de forma positiva para incentivar o aumento do consumo de hortaliças e frutas.

Assim, reconhece-se a importância do Programa de Alimentação Escolar como uma forma de intervenção positiva para incentivar, por exemplo, o aumento do consumo de hortaliças.

No planejamento da merenda escolar, os alimentos selecionados para integrarem o cardápio devem possuir alto valor nutritivo e ter boa aceitabilidade pelos escolares. Além disso, estes produtos devem ser de preparo rápido e fácil, devido à escassez de equipamentos, de tempo e de recursos humanos.

Uma alternativa para atender essas demandas parece ser a utilização dos Alimentos Minimamente Processados - AMP, considerados alimentos de conveniência.

Para avaliar a aceitação dos AMP, a utilização da análise sensorial tem sido um recurso de ampla utilização (Sasaki et al., 2001). A aceitação dos cardápios é um requisito fundamental para que se possa atingir os objetivos propostos pelo PAE (Meilgaard et al., 1990).

Verifica-se que, tendo por base a literatura especializada, há uma lacuna quando se buscam análises específicas sobre a utilização do AMP em programas públicos de alimentação e nutrição.

Visando preencher a lacuna de informações e análises, propôs-se a implementação da presente pesquisa, com os seguintes objetivos:

- avaliar o estado nutricional dos escolares;

- analisar quantitativamente e qualitativamente, o consumo alimentar dos escolares; 
- avaliar a contribuição das hortaliças e frutas integrantes da dieta, para o total de energia e nutrientes consumidos pelos escolares;

- verificar a aceitabilidade de hortaliças minimamente processadas pelos escolares. 


\section{REVISÃO DE LITERATURA}

\subsection{Consumo alimentar e estado nutricional}

Há extenso rol de evidências científicas registrando que o baixo consumo de frutas e hortaliças está associado com a maior probabilidade da ocorrência, em humanos, de doenças cardiovasculares e diversos tipos de câncer (Rojas, 2001).

Ness \& Powles (1997) e Fornés et al. (2000) verificaram que o consumo adequado de hortaliças e frutas diminui os riscos dos indivíduos desenvolverem doenças cardiovasculares.

Segundo Angelis (2001b) diversos estudos epidemiológicos apontam para o grande benefício do consumo adequado de frutas e hortaliças na prevenção de doenças crônico-degenerativas.

As revistas especializadas têm registrado, sistematicamente, nos últimos anos, as grandes mudanças ocorridas nos padrões alimentares da população brasileira.

Acumulam-se evidências também, de que o consumo alimentar exerce decisiva influência sobre o estado de saúde dos indivíduos de todas as idades. Nas últimas três décadas, têm sido intensamente destacados, pelos pesquisadores, que as características qualitativas da dieta são igualmente importantes na definição do estado de saúde, em particular no que se refere æ̀̀ doenças crônicas, que se manifestam mais freqüentemente na idade adulta. 
Por exemplo, a relação entre consumo de gorduras saturadas, níveis plasmáticos elevados de colesterol e risco de doença coronariana foi uma das primeiras a ser comprovada empiricamente (Keys, 1970).

De acordo com a Organização Mundial de Saúde, dietas ricas em carboidratos complexos são consideradas úteis na prevenção da obesidade e de vários tipos de câncer, no controle da hiperlidemia e do diabetes mellitus (WHO, 1995).

O consumo de frutas e hortaliças tem sido associado ao baixo risco de doenças cardiovasculares observadas em populações e, na maioria dos casos, tem merecido especial destaque o conteúdo de fibras consumidas (Angelis, 2001a).

Os vegetais são alimentos cuja importância para alimentação humana tem reconhecimento milenar, e representam uma excelente fonte de energia para condicionar a uma dieta saudável (Domene \& Vítolo, 2001).

Ainda com relação ao papel preventivo exercido pelos vegetais, vale ressaltar que uma dieta rica em frutas, verduras, legumes e grãos e, com baixo conteúdo de gorduras e energia, pode prevenir cerca de $35 \%$ dos casos de câncer. Muitas vitaminas, das quais as frutas e as hortaliças são as principais fornecedoras, desempenham papel importante na resistência contra o câncer e outras doenças degenerativas, por combaterem os radicais livres, considerados um dos principais elementos que contribuem para o surgimento das doenças (Junqueira \& Peetz, 2001).

Várias são as vantagens da inclusão de hortaliças na alimentação; além de constituírem fontes apreciáveis de vitaminas e sais minerais, a celulose contida nos referidos alimentos favorece o peristaltismo intestinal, promovendo o funcionamento eficaz dos intestinos. São geralmente pobres em proteínas e em gorduras e ricos em hidratos de carbono, como é o caso, por exemplo, da cenoura (Gonsalves, 1986).

No que se refere à produção brasileira de frutas, vale registrar que a mesma assumiu importante espaço no cenário internacional, ocupando lugar 
de destaque entre os principais países produtores. Esse setor responde por um Produto Interno Bruto - PIB, de US\$11 bilhões, gerando 4 milhões de empregos diretos (FNP Consultoria \& Comércio, 2001).

O Brasil ocupa o primeiro lugar no mundo na produção de laranja, banana e mamão, mantendo-se, também, entre os principais produtores de abacaxi, manga e uva (FNP Consultoria \& Comércio, 2001).

No entanto, de forma geral, ainda tem sido observado entre a população brasileira, um reduzido consumo de frutas e hortaliças. O esperado seria encontrar maior ingestão de frutas devido à facilidade de consumo em relação æ̀ hortaliças, mas não é isso que tem sido observado (FNP Consultoria \& Comércio, 1999).

Quando se considera o cenário internacional, pesquisa implementada por Andersen et al. (1995) revelou, que entre adolescentes noruegueses, o consumo de frutas supera o de hortaliças.

É interessante registrar também que análises baseadas em dados internacionais obtidos em pesquisa envolvendo 76.201 adolescentes mostraram que há clara associação (positiva) entre o nível de escolaridade dos pais e o consumo de vegetais crus pelos adolescentes de ambos os sexos (Roos et al., 2001).

Ao examinar a situação no Brasil, é possível verificar resultados, tendo por base os dados obtidos junto aos grupos de adolescentes, que há uma tendência à inadequação alimentar condicionada, em parte, pela carência de ingestão de frutas e hortaliças (Gambardella, 1996).

Pesquisa desenvolvida por Gambardella (1996) entre adolescentes paulistas também revela uma tendência de inadequação alimentar, especificamente no tocante àingestão de frutas e hortaliças.

No Brasil, nos últimos anos têm se tornado evidente as alterações da dieta alimentar, principalmente quando se considera os dados mais recentes das pesquisas sobre alimentação e nutrição. Os resultados apontam para a importância de adotar estratégias que estimulem a população a aumentar o 
consumo diário e com maior variabilidade de frutas e hortaliças. Tais ações podem ser consideradas como um dos mais potentes e eficazes meios de preservar a saúde e assegurar a qualidade de vida (Junqueira \& Peetz, 2001).

Análises de consumo envolvendo dois levantamentos de grande abrangência (Estudo Nacional de Despesas Familiares - ENDEF/1974 - 75 e a Pesquisa de Orçamentos Familiares - POF/1995 - 96) revelaram queda nos índices do consumo per capita de hortaliças, alcançando a proporção de 29,4\%. Essa constatação aponta para vários aspectos preocupantes, especialmente do ponto de vista da saúde pública, na medida em que as frutas e hortaliças representam uma das mais importantes respostas aos desafios alimentares contemporâneos. Entre esses desafios, há o predomínio da busca por uma dieta menos concentrada em gorduras, carboidratos simples e mais rica em fibras (Junqueira \& Peetz, 2001).

Atualmente, nas sociedades modernas, a dieta caracteriza-se por substancial fornecimento de energia na forma de gordura e de açúcar, que podem representar, respectivamente até $40 \%$ e $20 \%$ do total. Tal comportamento contribuiu para a diminuição do consumo de amido, que passou a fornecer $25 \%$ a $30 \%$ do total de energia (Domene \& Vítolo, 2001).

A referida modificação foi condicionada especialmente pela diminuição do consumo de alimentos vegetais in natura, e aumento do consumo de alimentos processados (Domene \& Vítolo, 2001).

Nos últimos anos, também tem sido notado, nas grandes cidades de países menos desenvolvidos, o aumento no consumo de alimentos transformados e um incremento no número de refeições realizadas fora do domicílio (Oliveira \& Thébaud-Mony, 1996 e Sampaio, 2001).

O Instituto Nacional de Alimentação e Nutrição - INAN (extinto nos anos 90), juntamente com universidades brasileiras, liderou uma pesquisa sobre o consumo alimentar de uma amostra da população brasileira - Estudo Multicêntrico sobre Consumo de Alimentos. Foi analisado o consumo alimentar de amostra de cinco cidades: Campinas, Curitiba, Goiânia, Ouro Preto e Rio de 
Janeiro. A pesquisa revelou que o tradicional prato de arroz com feijão não tinha mais a mesma aceitação, verificada durante décadas, entre a população brasileira. Mesmo sendo ainda considerado a base da dieta nacional, quando se compara os dados do ENDEF, realizado em meados da década de 70, o consumo de arroz e feijão, observado em 1996, diminuiu entre 15 e 30\% (arroz) e entre 16 e 38\% (feijão). Ao cardápio da população foram incorporados outros alimentos como, por exemplo, a carne, o frango, a salsicha, a maionese, o leite e os ovos (Galeazzi et al., 1997).

Ainda de acordo com o estudo multicêntrico, os alimentos in natura como os legumes e as frutas têm uma participação reduzida no consumo, pois, apenas $44 \%$ dos indivíduos que integraram a amostra da pesquisa, afirmaram consumir frutas e 58\%, legumes (Varella, 1997).

No que diz respeito ao consumo alimentar da população brasileira vale registrar que no período compreendido entre os anos de 1988 e 1996, houve um aumento da participação relativa de lipídios na dieta da população das regiões Norte e Nordeste, um aumento no consumo de ácidos graxos saturados em todas as áreas metropolitanas, ao lado da concomitante redução do consumo de carboidratos, da estagnação ou da redução do consumo de leguminosas, verduras, legumes e frutas e, ainda, do aumento no consumo (já considerado excessivo) de açúcar (Monteiro et al., 2000).

Esses são os traços marcantes e negativos da evolução do padrão alimentar, durante o período de 1988 a 1996. No entanto, vale registrar que ocorreram mudanças que podem revelar que a população aderiu a dietas mais saudáveis, comportamento que pode ser atestado pelo declínio do consumo de ovos e recuo discreto da elevada proporção de energia, proveniente de lipídios, registrado no Centro-Sul do país (Monteiro et al., 2000).

Situação similar é verificada quando se analisa os dados sobre o consumo de frutas e hortaliças entre as crianças e adolescentes, de vários países, entre eles, o Brasil. 
Um estudo realizado com 214 adolescentes (13 a 17 anos) da Costa Rica, com o objetivo de avaliar o consumo de frutas e hortaliças, obteve os seguintes resultados: o consumo médio diário de frutas (1,7 porções), não se distanciou da recomendação mínima de 2 porções por dia. No entanto, o consumo médio de vegetais (1,1 porções, incluindo as leguminosas) se revelou muito abaixo da recomendação mínima diária de 3 porções. Os adolescentes da zona urbana e as meninas consumiram uma quantidade significativamente menor de frutas e vegetais, em comparação com os jovens residentes nas áreas rurais e os adultos. Somente $30,4 \%$ dos adolescentes consumiram cinco ou mais porções de frutas e vegetais por dia (Rojas, 2001).

Segundo Doyle \& Feldmam (1997) uma pesquisa envolvendo estudantes de um colégio secundário, particular, tendo como público alvo indivíduos pertencentes à classe média de Manaus, mostrou que os alunos possuíam condições financeiras para comprar merenda e que aquelas consideradas mais nutritivas como frutas e sucos não apresentavam preços mais elevados quando comparados aos registrados para os lanches $\mathrm{e}$ refrigerantes. Porém, a preferência dos jovens recaiu sobre os lanches e refrigerantes. De acordo com os autores, os resultados revelaram que os fatores que influenciaram na escolha dos alimentos pelos alunos tinham origem, basicamente, nas famílias e, também, forte motivação da propaganda veiculada pela televisão.

No município de São Paulo os escolares revelaram consumir uma quantidade de hortaliças, legumes e frutas, considerada insuficiente para atender às recomendações nutricionais de vitamina $A$ e outros nutrientes, conforme preconizado na Recommended Dietary Allowance - RDA (Oliveira et al., 1998).

Um trabalho realizado por Gambardella (1996), mostrou que a alimentação de adolescentes brasileiros revela uma inadequação alimentar com carência de ingestão de produtos lácteos, frutas e hortaliças e excesso de açúcar e gordura. 
No Brasil, foi consolidada entre parcela substancial de jovens, a prática da alimentação que envolve o consumo de lanches, especialmente em estabelecimentos do tipo fast foods. Esses tipos de dietas freqüentemente são consideradas nutricionalmente inadequadas, apresentando alta quantidade de energia, com carência de ferro, cálcio, viaminas A e C (Carvalho et al., 2001).

Vale destacar que as necessidades de energia dos escolares variam conforme a idade e o gênero, de acordo com o registrado pela Recomended Dietary Allowances - RDA (National Research Council, 1989) e são mostradas a seguir (Quadro 1).

\begin{tabular}{|c|c|c|}
\hline \multirow{2}{*}{ Idade (em anos) } & \multicolumn{2}{|c|}{ Gênero } \\
\cline { 2 - 3 } & Masculino & Feminino \\
\hline $7-10$ & 2000 & 2000 \\
$11-14$ & 2500 & 2200 \\
\hline
\end{tabular}

Quadro 1 - Recomendação de energia (kcal) para os escolares, de acordo com a idade e o gênero.

Fonte: National Research Council (1989)

Deve ser registrado que as publicações científicas, no Brasil, tem identificado um baixo consumo de hortaliças e frutas entre os indivíduos pertencentes à faixa de idade entre 7 e 14 anos, que constituem o público alvo do tradicional Programa de Alimentação Escolar - PAE (Caroba ${ }^{1}, 1999$; Monteiro et al., 2000 e Silva, 1998b).

As crianças e adolescentes necessitam ingerir uma quantidade de alimentos que possibilite o alcance do pleno potencial genético de crescimento e desenvolvimento. O tamanho corporal que o indivíduo vai atingir na idade adulta merece atenção. $O$ indesejável atraso no crescimento traz conseqüências, na vida adulta, como mortalidade e morbidade, deficiências no

\footnotetext{
${ }^{1}$ CAROBA, D.C.R. Escolares e professores da rede pública de ensino: análises sobre o consumo alimentar e a influência da propaganda. Piracicaba: ESALQ, Depto. de Agroindústria, Alimentos e Nutrição/FAPESP, 1999. 15p.
} 
aprendizado e diminuição na capacidade física e intelectual (Philippi et al., 2000).

De acordo com Philippi et al. (2000), as crianças a partir dos 7 anos de idade começam a intensificar o processo de independência dos adultos. Na referida idade, as crianças já revelam suas próprias vontades e quando bem orientados são capazes de selecionar e consumir, de forma independente, seus alimentos. As refeições realizadas no domicílio e os lanches (merenda escolar) são excelentes oportunidades para a promoção de hábitos alimentares saudáveis. A forma de apresentação dos alimentos é importante, pois a criança se fixa nas cores, na forma e no visual, condições importantes para a aceitação dos alimentos.

Segundo Philippi et al. (2000), os períodos da vida pré-escolar, escolar e adolescência são excelentes momentos para uma orientação nutricional ativa e participativa que pode ser implementada no âmbito da escola e também pela família, sendo que, a alimentação deve ser saudável e adequada a cada uma destas fases, respeitando æ̀ características pessoais dos indivíduos.

A escola constitui-se num ambiente valioso para 0 desenvolvimento de ações educativas na área de nutrição e saúde e, também, por dispor de recursos, como é o caso na rede pública de ensino, do programa de alimentação escolar que deveria possibilitar aos alunos a oportunidade de acesso a alimentos saudáveis.

Antecedendo as considerações sobre a importância do programa de alimentação, implementado na totalidade das escolas públicas (item 2.2 desta seção), julgou-se pertinente, apresentar de maneira sintética, análises relativas ao estado nutricional de escolares, com especial destaque para a situação dos alunos da rede pública de ensino.

De acordo com Monteiro \& Conde (2000), a desnutrição na infância revelada pelo comprometimento severo do crescimento linear e/ou pelo emagrecimento extremo da criança, constitui um dos maiores problemas 
enfrentados por sociedades em desenvolvimento, seja pela sua elevada freqüência, seja pelo amplo expectro de danos que se associam àquelas condições.

Em decorrência do processo de transição nutricional, em curso no Brasil, a obesidade surge como um importante componente do comprometimento do estado nutricional da população.

Tem sido crescente, no Brasil, nas últimas décadas, o número de adolescentes com sobrepeso e obesidade.

De acordo com Mendes et al. (2001) os referidos distúrbios nutricionais observados, de forma precoce, entre os indivíduos, geralmente se associam ao surgimento e desenvolvimento de fatores de risco que poderão predispor, no futuro, quando adultos, à maior incidência de distúrbios metabólicos e funcionais.

Frutuoso (2000) registra que as conseqüências imediatas da obesidade podem ser traduzidas pela sua influência na saúde, suas repercussões psicossociais e impacto na qualidade de vida. A longo prazo, associa-se a problemas debilitantes da saúde, além de constituir fator de risco para doenças crônicas não transmissíveis, entre elas, o diabetes mellitus, hipertensão arterial, dislipidemias, doenças cardiovasculares e cânceres.

Moura \& Sonati (1998) desenvolveram pesquisa envolvendo 194 escolares e observaram elevada ingestão de lipídios na dieta, sendo que 22,8\% destas crianças apresentavam colesterol plasmático acima de $170 \mathrm{mg} / \mathrm{dl}$.

De acordo com os referidos autores, os resultados podem ser considerados como fortes argumentos para justificar a implantação, a curto prazo, de programas de intervenção.

Ainda com relação ao estado nutricional, é importante destacar que no final da década de 80 , um levantamento nacional identificou $15,6 \%$ de prevalência de altura (déficit de crescimento), enquanto a Pesquisa Nacional da Saúde - PNS (1996) em meados da década de 90, encontrou 10,6\% de crianças com déficit de crescimento (Silva et al., 1999a). 
A distribuição da prevalência de desnutrição crônica, está longe de ser homogênea, quando se considera a realidade brasileira. Note-se que no início da década de 90, Guerra (1993), por meio de censo antropométrico de escolares, do estado do Ceará, encontrou $17,23 \%$ de prevalência de déficit de altura enquanto, outras pesquisas implementadas, em regiões mais ricas do país, revelam valores muito menores, como é o caso, por exemplos, dos estados de São Paulo, Santa Catarina e Paraná (Silva et al., 1999a).

Tendo em vista o local onde foi desenvolvida a presente dissertação, dados específicos dos escolares da rede pública de Piracicaba serão apresentados a seguir, em breve relato.

Nos últimos anos, diversas pesquisas foram realizadas no município de Piracicaba, com o objetivo de conhecer a situação nutricional de escolares matriculados na rede pública de ensino. Entre essas, merece destaque à avaliação, implementada em 1995, tendo por base informações de peso e altura de 16.093 alunos das escolas das regiões urbana e rural, com a adoção, dos indicadores de altura para idade - ZAl e a distribuição dos percentis do Índice de Massa Corporal - IMC (Silva et al., 1999a).

Os resultados revelaram proporção de $4,18 \%$ de escolares com ZAK - 2 (indicativo de déficit de altura), enquanto em população adotada como referência, é observado aproximadamente 2,3\%.

Trata-se portanto, de situação muito favorável, pois descontandose da proporção verificada (4,18\%), o percentual esperado (cerca de $2,3 \%$ ) de crianças geneticamente baixas, observa-se apenas 1,9\% de escolares com indicativo de desnutrição crônica. Quando se analisa a situação no tocante ao estado nutricional atual (adoção dos indicadores: escore $Z$ de peso para altura ZPA e percentis do IMC), foi possível verificar que, entre os escolares com idade inferior a 10 anos $(n=7.362$ do total de 16.093), a proporção de baixo peso (ZPA $<-2$ ) não atingiu $2 \%$, ou seja, valor muito abaixo do esperado (aproximadamente 2,3\%). Para os alunos mais velhos $(n=8.731)$, adotando-se como indicador o IMC $<15^{\circ} \mathrm{P}$ (indicativo de baixo peso) e IMC $\geq 85^{\circ} \mathrm{P}$, para 
caracterização de sobrepeso, foram observadas proporções de 4,9\% e 23,8\%, respectivamente.

De acordo com as análises implementadas por Silva et al. (1999a), vale destacar que em populações de referência, espera-se encontrar $15 \%$ de indivíduos com IMC < 15\% P. Portanto, a situação dos alunos, participantes da pesquisa, quando se considera a condição de "baixo peso" é muito favorável. No entanto, a prevalência de sobrepeso merece atenção, tendo em vista que supera, em 8,8 pontos percentuais o valor adotado como referência (15\%). As análises permitem afirmar que o resultado mais preocupante, quando se considera a avaliação nutricional, tendo por base indicadores antropométricos, é o sobrepeso.

Pesquisa realizada por Caroba (2002), envolvendo amostra representativa de 578 alunos (adolescentes) da rede pública de ensino, revelou que $4,0 \%$ do grupo foi classificado com ZAl $<-2$. Trata-se portanto de situação praticamente idêntica àquela encontrada, em meados da década de 90 (Silva et al., 1999a). Quanto à prevalência de sobrepeso (IMC $\geq 85^{\circ} \mathrm{P}$ ) o referido autor encontrou proporção $(22,1 \%)$ que merece atenção, tendo em vista que supera a esperada (15\%).

Transcorridos praticamente 6 anos entre os períodos dedicados aos levantamentos de dados das referidas pesquisas (Caroba, 2002; Silva et al., 1999a) é possível inferir que a situação se manteve praticamente inalterada. Registra-se, também, que persistiu a preocupação com os resultados referentes ao sobrepeso.

A presente pesquisa envolve em uma de suas seções, análises de dados antropométricos, obtidos no ano de 2001, visando conhecer a situação nutricional dos escolares. 


\subsection{O Programa de Alimentação Escolar - PAE}

Vale lembrar que entre os diversos programas de alimentação e nutrição que vigoram no Brasil, destaca-se o Programa de Alimentação Escolar - PAE, implementado na totalidade dos municípios brasileiros ${ }^{2}$.

Pesquisas mais recentes, tendo por base uma amostra de indivíduos em idade escolar, têm apontado para o baixo consumo de hortaliças e frutas (Gambardella et al., 1999 e Silva, 1998b).

Nas escolas públicas e filantrópicas, da totalidade dos municípios brasileiros, é implementado (desde meados da década de 50) o Programa de Alimentação Escolar ou o Programa de Merenda Escolar - PME, como é também conhecido o programa governamental. Esse programa é considerado como um dos maiores, em seu gênero, quando comparado à realidade internacional e tem por objetivo distribuir alimentos, gratuitamente, para os alunos com idade entre 7 a 14 anos, durante a jornada de aulas (Salay \& Carvalho, 1995).

O Programa de Alimentação Escolar deve assumir um papel fundamental na instituição de ensino. As atividades relacionadas com a educação nutricional devem ser incorporadas ao currículo da escola, com o objetivo de contribuir para que os escolares melhorem seus conhecimentos sobre o valor nutricional e sobre a importância dos alimentos, para que possam consolidar hábitos alimentares saudáveis (Brandão, 2000).

A escola se apresenta como um espaço onde é possível implementar programas que visam a promoção da saúde, por ser um local onde os escolares passam grande parte do seu tempo (Costa et al., 2001).

\footnotetext{
${ }^{2}$ O Programa de Alimentação Escolar vigora no Brasil há 50 anos e destina-se àtotalidade das crianças que freqüentam escolas públicas ou filantrópicas. Estimativas governamentais apontam para 0 atendimento diário (em 2002) de 35,4 milhões de estudantes brasileiros (Brasil, 2002).
} 
Silva (1996) relatou que em 1983, o Estado de São Paulo iniciou em caráter experimental, as experiências de descentralização do PAE. O referido processo, conduzido experimentalmente durou até o ano de 1989, com a participação de muitos municípios e o atendimento de número considerável de alunos.

É importante destacar, que a implementação progressiva no Brasil, da municipalização da merenda escolar a partir da década de 90, possibilitou a ampliação para o exercício dos direitos, a autonomia da gestão municipal, o controle, a potencialização de instrumentos adequados para o uso e redistribuição mais eficiente dos recursos públicos para reverter æ̀̀ tendências globalizantes de planejamento (Brasil, 1997).

Outro aspecto importante a ser considerado é a oportunidade que pequenos e médios produtores, assim como as agroindústrias locais e regionais passaram a dispor para se envolver, de forma mais consistente, com o PAE (Silva et al., 1999b).

No entanto, sabe-se que o atendimento do PAE está longe de ser homogêneo, existindo municípios, que mesmo após o processo de municipalização, ainda apresentam elevadas proporções de escolares que recusam, voluntariamente, a merenda. $\mathrm{Na}$ maioria dos casos, essa rejeição (observada mesmo entre grupos de menor renda) é condicionada pela baixa qualidade dos alimentos oferecidos, inadequação das preparações aos horários em que são distribuídas e principalmente, o não atendimento das preferências alimentares dos beneficiários do programa.

Assim, parece ser altamente recomendável que esforços sejam empreendidos, para a melhor utilização dos recursos destinados ao programa, buscando-se de forma mais decisiva a sua maior eficácia.

Desse modo, espera-se que os resultados da presente pesquisa ofereçam, entre outros, subsídios, por exemplo, para os formuladores de políticas públicas, que necessitem elaborar reformulações de cardápios, com vistas à incorporação de novos alimentos objetivando uma maior adesão dos 
escolares ao programa e, também, envolvimento de produtores de alimentos dos próprios municípios no processo de operacionalização do PAE.

Recentemente, novas técnicas de processamento de alimentos têm sido disponibilizadas, especialmente, com o objetivo de atender a demanda por alimentos seguros e de conveniência. Na próxima seção da dissertação será dedicada maior atenção para as hortaliças minimamente processadas.

\subsection{Hortaliças minimamente processadas}

Tendo em vista a importância que pode assumir, o setor de produção de hortaliças minimamente processadas, tanto no que se refere aos aspectos econômicos, quanto ao alimentar e nutricional (especialmente para o grupamento infantil), tece-se a seguir, algumas considerações sobre o tema.

O processamento mínimo de hortaliças foi introduzido no país, na década de 90 por algumas empresas motivadas pelas tendências do mercado, que indicavam o crescimento da demanda por alimentos considerados de conveniência ou de fácil preparo. Vale notar que os setores que vem incorporando, com rapidez, a aquisição desses novos alimentos são os serviços de fornecimento de alimentos prontos para consumo e de preparo rápido (fast food), os hotéis, restaurantes, lanchonetes e redes de supermercados. Estes produtos são considerados de conveniência, pois permitem um maior aproveitamento do tempo decorrente da redução do período de preparo, melhor padronização da qualidade e redução das perdas.

Agregando qualidade e conveniência para o consumidor, 0 mercado de saladas prontas (fresh cuts) vem revelando substancial expansão no Brasil. Uma pesquisa brasileira realizada no ano de 2000 mostrou que oito empresas disputavam um mercado de $\mathrm{R} \$ 100$ milhões por ano. Nos Estados Unidos, esse mercado movimentava em torno de US\$10 bilhões por ano, 11\% de todo o mercado de frutas, legumes e verduras - FLV. O mercado potencial 
brasileiro no segmento de Fresh Cuts poderá crescer até cem vezes na primeira década do século XXI (Ferreira, 2000).

O volume comercializado de hortaliças cresceu $20 \%$ na última década dos anos 90, segundo dados da Associação Brasileira de Supermercados e os pedidos para aquisição de hortaliças minimamente processadas, somente quando se considera, por exemplo, a rede Carrefour, aumentaram em 50\% em um ano. No Brasil, calcula-se que o volume de vendas deverá chegar a US\$150 milhões até 2003 (Pilon et al., 2002a e Rabello, 1999).

Segundo o Produce Marketing Association - PMA, nos Estados Unidos, as vendas de vegetais minimamente processados alcançaram US\$7,9 bilhões em 1997, prevendo-se um crescimento para US\$ 19 bilhões até 2003. Acredita-se que estes produtos atualmente representam 10\% de todas as vendas de frutas e hortaliças (Junqueira \& Luengo, 1999).

Segundo Bittencourt et al. (2000a) os avanços tecnológicos têm possibilitado à indústria de alimentos suprir a demanda, durante todo 0 ano, com qualidade, de grande variedade de hortaliças e frutas, na forma de minimamente processadas.

O apelo por alimentos frescos, com reduzido conteúdo de energia, nutritivos e de alta qualidade é cada vez maior. Os consumidores vêm modificando seus hábitos alimentares e, cada vez mais, reconhecem a relação direta entre alimentação e prevenção de doenças (Maistro, 2001).

As agências governamentais e organizações americanas têm registrado, com ênfase, a recomendação para o aumento do consumo de vegetais, frutas e cereais.

Os alimentos frescos são reconhecidos, por parcela dos consumidores, como aqueles que são mais nutritivos e saborosos, quando comparados aos produtos alimentícios industrializados. Frutas e hortaliças frescas, pré-preparadas, tornam-se cada vez mais populares nos EUA como itens de conveniência, face à praticidade obtida por meio das etapas do pré- 
preparo, que possibilitam a comercialização dos alimentos lavados, descascados, cortados e empacotados (Maistro, 2001).

Skura \& Powrie (1995), estimaram que no ano de 1995, mais da metade dos dólares gastos em lojas de conveniência com a compra de alimentos, foram despendidos na aquisição de itens prontos para o consumo (ready-to-eat), dentre esses, merecem destaque os alimentos minimamente processados.

As hortaliças minimamente processadas constituem uma classe que vem conquistando o consumidor de forma crescente e consistente. A sua aquisição proporciona ao consumidor, o acesso a um produto muito parecido com o fresco, com uma vida útil prolongada e, ao mesmo tempo, tem garantia de segurança desde que sejam mantidas a boa qualidade nutricional, sanitária e sensorial (Willey, 1997).

Os alimentos minimamente processados são produtos in natura que tanto podem ser comercializados prontos para consumo, como também, integrar, com facilidade, a preparação de uma ampla variedade de pratos.

É pertinente, incluir nesta seção algumas considerações sobre as variedades dos produtos minimamente processados, adotando como referência a publicação de Chitarra (1998) que registrou alguns exemplos dos referidos alimentos, que podem ser observados a seguir:

- cenoura (descascada, fatiada em palitos, pedaços, rodelas ou raladas); vagens (cortadas); aipo (palitos, fatias); batata (descascada e fatiada); pepino (fatiado, metades, rodelas); couve-flor (floretes individuais, com ou sem o talo); brócolis (floretes individuais, com ou sem o talo); repolho (cortado); beterraba (descascada e ralada, cortada, fatiada); milho-verde (descascado e cortado); alface (limpa, sem o miolo, inteira, picada em tiras ou pedaços); espinafre (limpo, aparado); tomate (fatiado, metades, picado); cebola (fatiadas em anéis, picadas); saladas (misturas de uma larga variedades de hortaliças ou frutos). 
Não sobram dúvidas que a obtenção de um produto final que atenda æ̀s exigências de qualidade, demanda atenção para as características da matéria-prima a ser utilizada, com especial ênfase para o atributo qualidade.

Vale ressaltar que a deterioração de alimentos minimamente processados e refrigerados é um fenômeno complexo, que envolve alterações físico-químicas, bioquímicas e biológicas e, os principais mecanismos de deterioração que afetam esse tipo de produto são: a perda de umidade, oxidação e o crescimento microbiano (Bittencourt et al., 2000b).

A qualidade é definida como o conjunto de características que diferenciam unidades de um produto e que têm significância na determinação do grau de aceitabilidade pelo consumidor (Chitarra, 1998).

Os requisitos de qualidade se relacionam com o mercado de destino, armazenamento, consumo in natura ou processamento e são agrupadas em três categorias (sensoriais, nutricionais e segurança), devendo ser consideradas em conjunto não só para satisfazer as preferências do consumidor, mas também, para proteção da saúde dos mesmos (Chitarra, 1998).

O monitoramento e a avaliação da qualidade dos alimentos devem ser implementados desde o campo até o consumo, visando possibilitar o conhecimento do valor real do produto e da sua capacidade de conservação e aceitabilidade, com base em padrões pré-estabelecidos.

Surge daí a necessidade do conhecimento das principais transformações fisiológicas e bioquímicas da matéria-prima, como suporte para a aplicação de tecnologias adequadas, que não só contribuam para a redução das perdas pós-colheita, como também para um maior desenvolvimento da agroindústria no Brasil.

Nos últimos anos tem crescido o interesse dos consumidores pelos atributos de qualidade dos alimentos. Vale lembrar que a segurança é um dos requisitos de qualidade mais considerado pelos consumidores, na decisão para compra, especialmente para aqueles que pertencem aos estratos de maior 
renda e elevada escolaridade. Quando se consideram os alimentos minimamente processados, especialmente as hortaliças, é importante lembrar que as mesmas devem ser isentas de toda e qualquer substância química que possa causar danos à saúde do consumidor. Os padrões de segurança são estabelecidos por leis federais ou estaduais, visando à preservação da saúde pública. Supõe-se, portanto, a prevenção do desenvolvimento de microrganismos patogênicos ou prejudiciais, bem como na proteção contra a presença de substâncias tóxicas naturais ou contaminantes (resíduos de defensivos agrícolas ou de outros produtos).

As atividades das agroindústrias que se dedicam à produção dos alimentos minimamente processados são recentes, e, portanto, há necessidade de adoção das normas de boas práticas de produção dos alimentos, que devem, obrigatoriamente, apresentar qualidade, durabilidade e segurança para serem consumidos.

Quanto à "vida de prateleira" do produto é interessante lembrar que de acordo com a Chitarra (1998), é o espaço de tempo no qual há manutenção da qualidade (aparência, cor, textura, sabor, aroma, valor nutritivo, segurança) em níveis aceitáveis para o consumo.

Chitarra (1998) observou que a vida de prateleira para produtos refrigerados pode ser curta como, por exemplo, de apenas 5 dias para cogumelos fatiados ou longa (18 dias) para alface limpa e sem o miolo. Frutos inteiros frescos e hortaliças sob temperatura de -1 a $4^{\circ} \mathrm{C}$ podem ter vida de prateleira de 1 a 5 dias, como o morango ou de 8 a 30 semanas como maçãs e pêras.

Vale registrar a realização de pesquisa, tendo como amostra, cenoura minimamente processada, e que envolveu também, análises físicoquímicas e microbiológicas aos 7, 14 e 21 dias de armazenamento (as cenouras foram embaladas sob ar atmosférico, vácuo e atmosfera modificada e armazenadas sob refrigeração a $1^{\circ} \mathrm{C}$ ). Os resultados revelaram que os teores de vitamina $\mathrm{C}$ não foram afetados durante o processamento. Para os minerais 
foram identificadas modificações para o cobre $(\mathrm{Cu})$, manganês $(\mathrm{Mn})$, zinco $(\mathrm{Zn})$, fósforo $(\mathrm{P})$ e magnésio $(\mathrm{Mg})$, durante o período de armazenamento, sendo que houve uma diminuição significativa no teor do cobre, durante as duas últimas semanas, atingindo praticamente a metade do valor inicial $(8,9$ a $4,9 \mathrm{~g} / \mathrm{kg})$. Quando se analisou o Mn, Zn, P e o Mg, foi possível verificar que se mantiveram praticamente estáveis durante esse período (Mn: 14,66 - 18,91g/kg; Zn: 24,51 - 27,06 g/kg; P: 2,13 - 2,77 g/kg; Mg: 0,65 - 0,99 g/kg) (Pilon et al., 2002b).

Segundo Pilon et al. (2002b) o resultado das "análises microbiológicas das amostras de cenoura minimamente processada foi negativo para coliformes totais e fecais, para anaeróbios mesófilos e para Salmonella. Durante apenas o período de armazenamento, quando se considera todos os tratamentos, apenas os psicrotróficos apresentaram crescimento".

Ainda de acordo com os referidos autores, foi observado que a cenoura embalada sob ar atmosférico manteve 0 teor de $\beta$-caroteno praticamente constante durante as três primeiras semanas de armazenamento, pouco diferindo da condição de embalagem a vácuo. No entanto, vale registrar que menor teor foi observado, quando se considerou a embalagem com atmosfera modificada.

Conforme descrito anteriormente, o propósito da elaboração de alimentos minimamente processados e refrigerados é proporcionar ao consumidor um produto conveniente, muito parecido com o fresco, porém com sua vida útil prolongada, com a manutenção da qualidade nutritiva e sensorial, ao mesmo tempo garantir a sua segurança.

Reconhecendo a importância cada vez mais crescente da segurança de alimentos, Sant'Ana et al. (2002) realizaram levantamento dos perigos biológicos associados ao processamento de hortaliças minimamente processadas, tendo por base legislação recente. É importante esclarecer que a referida legislação intitula-se Brasil - Resolução Anvisa/ MS ( $n$ - 12 de janeiro de 2001). Entre os resultados, merece destaque a contagem elevada de coliformes 
e presença de Escherichia coli em $62 \%$ e $26 \%$ das amostras e ainda, verificou que $33,3 \%$, encontravam-se em desacordo com os padrões microbiológicos legais vigentes (especialmente no que se refere à Escherichia coli). Os resultados sugerem probabilidade elevada de ocorrência de toxiinfecções alimentares. Os autores enfatizam que uma etapa crucial, como a sanificação, é crítica para a segurança do produto, necessitando portanto, de um maior controle de tempo de exposição e concentração do sanificante adotado.

Merece registro, também no que tange aos pontos que representam perigo e riscos que não são controlados nos estabelecimentos de processamento, as condições de armazenamento nos pontos de venda, sendo a temperatura, umidade relativa e composição atmosférica no interior da embalagem, os fatores mais importantes que incidem sobre o efeito da estocagem na microbiota (Sant'Ana et al., 2002).

Registra-se que os minerais, presentes nos alimentos, são estáveis ao calor. Desse modo, as perdas desses nutrientes, encontrados nos alimentos ocorrem, de forma predominante, durante as operações de descascamento, lavagem, corte e branqueamento. Pode ocorrer também a diminuição na disponibilidade de alguns íons como cálcio, ferro e zinco, pela interação com outros componentes dos alimentos como, por exemplo, oxalatos, fitatos e taninos (Sales, 1988).

Da mesma forma que os minerais, perdas significativas de vitaminas hidrossolúveis ocorrem nas operações de processamento como a lavagem, descascamento, branqueamento etc. As vitaminas são, também, sensíveis ao pH do meio, temperatura, exposição à luz e ao oxigênio (Sales, 1988).

Os açúcares e os lipídios são os principais componentes energéticos dos alimentos $\mathrm{e}$ as perdas desses nutrientes são pouco expressivas do ponto de vista quantitativo (Sales, 1988).

Em relação æ̀s proteínas, há possibilidade de ocorrerem perdas devido ao tratamento térmico moderado, em presença de açúcares e também, 
pelo tratamento mais drástico na ausência ou presença de baixas concentrações de carboidratos. Em condições moderadas, as perdas de proteínas decorrem principalmente das interações com carboidratos e na oxidação dos lipídios (Sales, 1988).

Essa modalidade de processamento de frutas e hortaliças, embora mínimo frente a tratamentos como pasteurização, esterilização e congelamento, torna os vegetais mais sensíveis aos processos de deterioração, quando se estabelece a comparação com aquelas mantidas inteiras. Isto ocorre porque a manipulação do alimento e a exposição aos equipamentos durante o processo, provocam o rompimento dos tecidos e conseqüente mistura do conteúdo celular, acarretando inúmeras reações químicas, oxidativas ou não (Sarantópoulos et al., 2001).

O uso da refrigeração é uma das melhores formas para reduzir o metabolismo e conservar as propriedades dos produtos fresh-cut, sendo recomendada, para a maioria dos produtos, temperaturas próximas a $0^{\circ} \mathrm{C}$. Utilizando-se conjuntamente o recurso da baixa temperatura e a tecnologia de acondicionamento em atmosfera modificada obtém-se um efeito sinergístico, que reduz ainda mais a taxa metabólica e o processo de amadurecimento do produto, mantendo o frescor e a qualidade durante períodos mais longos (Sarantópoulos et al., 2001).

De acordo com Sarantópoulos et al. (2001), devido à qualidade, praticidade e conveniência que os referidos produtos proporcionam ao consumidor, os mesmos têm obtido grande êxito de mercado, sendo o sistema de embalagem e a temperatura requisitos essenciais para o sucesso da tecnologia.

O processamento mínimo agrega valor ao produto e, conseqüentemente aumenta a competitividade do setor de produção, proporcionando meios alternativos de comercialização para os agentes envolvidos nas operações. Dessa maneira, é possível minimizar as perdas da matéria-prima, com benéficas repercussões econômicas, sociais e ambientais. 
No entanto, a matéria-prima utilizada deve ser de qualidade superior e, todas as etapas de produção (colheita, processamento, embalagem, armazenamento e comercialização) devem ser otimizadas.

Cabe salientar que, mais recentemente, tem sido observado, no Brasil, um crescente interesse, manifestado por técnicos da área de tecnologia de alimentos, pela pesquisa que motivem o desenvolvimento de novas tecnologias, a serem adotadas pelas agroindústrias. Mesmo atraindo a atenção de pesquisadores, ainda é notória a escassez, no país, de trabalhos científicos sobre o tema. A lacuna é ampliada quando são buscadas análises específicas sobre a utilização de produtos minimamente processados em programas e serviços de alimentação e nutrição.

Deve-se reconhecer que os alimentos minimamente processados constituem-se um recurso valioso para a incorporação, especialmente, de hortaliças, no cardápio dos beneficiários dos programas públicos de alimentação e nutrição.

Vale registrar que uma alternativa a ser analisada para atender uma crescente demanda, é a implantação, por cooperativas de agricultores, de unidades processadoras de alimentos minimamente processados, em municípios onde a produção de hortaliças e frutas se revela substancial.

\subsection{Análise sensorial}

A história da humanidade registra como a utilização de plantas e ervas aromáticas influenciou o comportamento de vários povos. Há relato de uma ampla lista de materiais odoríferos que tiveram importância para os antigos povos egípcios, por exemplo, a mirra e diversas resinas (Chaves, 1993).

Na Índia do século IX, substâncias resinosas e odoríferas (ervas e condimentos, manteiga e óleos) eram largamente utilizadas. Acredita-se que a descoberta da América e do Brasil está indiretamente relacionada com a demanda européia por especiarias, ervas e condimentos (Chaves, 1993). 
Em tempos mais recentes, tornou-se evidente para os pesquisadores que trabalhavam para o exército americano, que o adequado estado nutricional dos soldados não era alcançado somente com a formulação de refeições balanceadas dieteticamente, pois isso não garantia a aceitação dos alimentos pelos militares. Segundo o referido autor foi dessa maneira que as propriedades sensoriais na aceitação dos alimentos ganhou reconhecimento (Chaves, 1993).

Nos últimos anos, a análise sensorial tem alcançado uma ampla difusão, especialmente quando se considera a crescente preocupação em atender as preferências dos consumidores. Com o aumento no número de indústrias de alimentos e bebidas, após a segunda guerra mundial, a análise sensorial de alimentos passou a merecer reconhecimento. As indústrias passaram a buscar a qualidade sensorial e sua manutenção nos produtos e, a redução dos riscos de rejeição de novos gêneros por parte do consumidor (Almeida, 1996 e Penna, 1999).

É importante lembrar que a análise sensorial se concretiza pela interpretação dos resultados registrados por meio dos sentidos humanos: visão, paladar, olfato, audição e tato (Teixeira et al., 1987).

A avaliação sensorial tem diversas aplicações, entre elas, merecem destaque o controle de garantia da qualidade, o desenvolvimento de novos produtos e melhoria dos alimentos disponíveis no mercado (Almeida, 1996 e Costell \& Duran, 1981).

A análise sensorial de alimentos é função primária do homem. Desde a infância, de forma mais ou menos consciente, os indivíduos aceitam ou rejeitam os alimentos de acordo com a sensação que experimentam ao observá-los ou ingeri-los. Esse aspecto de qualidade, que incide diretamente na reação do consumidor, é denominado qualidade sensorial. Sua importância tecnológica e econômica é evidente, pois, em última instância, pode condicionar as inovações da área de ciência e da tecnologia de alimentos ao sucesso ou ao fracasso (Chaves, 1993). 
Nos testes afetivos são medidas as atitudes subjetivas, tais como aceitação ou preferência de um produto. A tarefa do provador consiste em indicar a preferência ou aceitação por meio de seleção, ordenação ou pontuação das amostras. A utilização da escala hedônica é um exemplo deste tipo de teste. Os julgadores são normalmente consumidores rotineiros ou potenciais de um produto. Nos testes de aceitação realizados, com o envolvimento de grupos amostrais da população-alvo, o número mínimo de provadores, freqüentemente varia de 75 a 200 ou até com a participação de um maior número de provadores (Chaves, 1993).

$\mathrm{Na}$ realização dos testes é interessante lembrar que de acordo com Teixeira et. al. (1987) as principais vantagens da utilização da escala hedônica são: demandar menos tempo para avaliação, apresentar procedimentos muito mais interessantes para o provador e pode ser utilizada por grupos de participantes da pesquisa pouco ou ainda não previamente treinados.

De acordo com Brandão (2000) e Teixeira et al. (1987), no método da escala hedônica assume-se que respostas diretas com base em sensações, têm maior validade, quando comparadas com àquelas, especialmente dependentes da razão quando se objetiva predizer o comportamento do consumidor em relação ao alimento. Tanto a escala, quanto às instruções devem ser preparadas visando a adoção das mesmas, na realização dos testes que envolvam indivíduos sem prévia experiência em participar de análises sensoriais de alimentos.

Os testes de aceitação poderão indicar as perspectivas de aprovação do produto no mercado ou se haverá necessidade de ser submetido à etapa de aperfeiçoamento (Chaves, 1993). Portanto, não sobram dúvidas sobre a importância dos resultados obtidos por meio da adoção dos referidos testes para subsidiar a elaboração, pelas empresas, de estratégias eficientes para alcance de metas que visem conquistar maior número de consumidores. 


\section{MATERIAL E MÉTODOS}

\subsection{Local da Pesquisa}

A pesquisa foi desenvolvida na cidade de Piracicaba, Estado de São Paulo.

De acordo com os dados do censo de 2000 realizado pelo Instituto Brasileiro de Geografia e Estatística - IBGE (2002), o município de Piracicaba ocupava uma área territorial de $1.368 \mathrm{~km}^{2}$, com uma população residente de 329.158 habitantes (162.433 homens e 166.725 mulheres).

Piracicaba possuía, em 2001, 97 unidades de ensino pré-escolar, 85 de ensino fundamental e 26 de ensino médio (Instituto Brasileiro de Geografia e Estatística - IBGE, 2002).

A seguir, apresenta-se, sinteticamente, algumas informações referentes ao município de Piracicaba, organizadas no Quadro 2. 


\begin{tabular}{|l|c|c|c|}
\hline \multirow{2}{*}{ INDICADORES } & \multicolumn{3}{|c|}{ ANOS } \\
\cline { 2 - 4 } & 1970 & 1980 & 1991 \\
\hline \multirow{2}{*}{ Índice de Condições de Vida - ICV } & 0,70 & 0,76 & 0,82 \\
\cline { 2 - 4 } & $(0,53)$ & $(0,65)$ & $(0,72)$ \\
\hline \multirow{2}{*}{$\begin{array}{l}\text { Renda per capita (Salário Mínimo de } \\
\text { setembro de 1991) }\end{array}$} & 0,99 & 2,44 & 2,11 \\
\cline { 2 - 4 } & $(0,63)$ & $(1,43)$ & $(1,31)$ \\
\hline \multirow{2}{*}{$\begin{array}{l}\text { Proporção de pessoas com rendimento } \\
\text { insuficiente (\%) }\end{array}$} & 39,80 & 6,85 & 12,05 \\
\cline { 2 - 4 } & $(67,90)$ & $(39,47)$ & $(45,46)$ \\
\hline \multirow{2}{*}{ Abastecimento de água adequado (\%) } & 85,30 & 92,40 & 97,10 \\
\cline { 2 - 4 } & $(51,26)$ & $(70,00)$ & $(83,50)$ \\
\hline \multirow{2}{*}{ Instalação adequada de esgoto (\%) } & 82,40 & 87,10 & 89,80 \\
\cline { 2 - 4 } & $(42,30)$ & $(52,90)$ & $(58,90)$ \\
\hline \multirow{2}{*}{$\begin{array}{l}\text { Proporção de crianças de 7 a 14 anos de } \\
\text { idade que não freqüentam a escola (\%) }\end{array}$} & 20,00 & 16,70 & 10,40 \\
\cline { 2 - 4 } & $(32,60)$ & $(32,80)$ & $(22,70)$ \\
\hline $\begin{array}{l}\text { Proporção de crianças de 10 a 14 anos } \\
\text { que trabalham (\%) }\end{array}$ & 12,90 & 13,90 & 7,70 \\
\cline { 2 - 4 } & $(12,40)$ & $(12,90)$ & $(8,60)$ \\
\hline
\end{tabular}

Quadro 2 - Indicadores socioeconômicos do município de Piracicaba, São Paulo, nos anos 1970, 1980 e 1991.

Fonte: Instituto Brasileiro de Geografia e Estatística - IBGE (1998)

Nota: os números entre parênteses são os indicadores obtidos para o Brasil. 


\subsection{População de estudo}

Para o alcance dos objetivos da pesquisa foi sorteada uma escola (pertencente à rede pública de ensino do município de Piracicaba), representativa de cada uma das 6 regiões da cidade (não foram incluídas as unidades da zona rural), obtendo-se um total de 6 escolas. Em cada unidade foram sorteados 35 alunos. Desse modo, a amostra foi constituída por 210 escolares (percentagens iguais de indivíduos do gênero masculino e do feminino, contemplando, também, a representação do conjunto de alunos com idade entre 7 a 14 anos). Trata-se, portanto de uma amostra estratificada proporcional. As informações relativas às escolas e respectivos alunos são mostradas nas Tabelas 1 e 2 , apresentadas a seguir.

Tabela 1. Distribuição das escolas públicas e alunos sorteados para integrarem a amostra. Piracicaba, 2001.

\begin{tabular}{|c|c|c|c|c|c|}
\hline \multirow{3}{*}{$\begin{array}{l}\text { Localização } \\
\text { (Região) }\end{array}$} & \multirow[t]{3}{*}{ Escolas } & \multicolumn{3}{|c|}{ №-de alunos matriculados } & \multirow{3}{*}{$\begin{array}{c}\mathrm{N} 0^{\circ} \text { de } \\
\text { alunos } \\
\text { integrantes } \\
\text { da amostra }\end{array}$} \\
\hline & & Região & Escola & Escola & \\
\hline & & & & Vespertino & \\
\hline Região I & E.E. Prof. José de Mello Moraes (I) & 16.189 & 1.519 & 393 & 35 \\
\hline Região II & E.E. João Guidotti ${ }^{(2)}$ & 6.888 & 1.097 & 297 & 35 \\
\hline Região III & E.E. Dr. Dario Brasil ${ }^{(3)}$ & 8.978 & 1.257 & 370 & 35 \\
\hline Região IV & E.E. Augusto Melega ${ }^{(4)}$ & 6.725 & 350 & 176 & 35 \\
\hline Região V & E.E. Mons. Jeronymo Gallo ${ }^{(5)}$ & 7.207 & 1.808 & 634 & 35 \\
\hline Região VI & E.E. Dr. Luiz G. de Campos Toledo ${ }^{(6)}$ & 6.542 & 745 & 290 & 35 \\
\hline Total & & 52.529 & 6.776 & 2.160 & 210 \\
\hline
\end{tabular}

Nota: os números entre parênteses são os códigos atribuídos às escolas. 
Tabela 2. Distribuição da amostra dos alunos matriculados nas unidades de ensino, de acordo com o gênero e a idade. Piracicaba, 2001.

\begin{tabular}{ccccccccc}
\hline $\begin{array}{c}\text { Idade } \\
\text { (Anos) }\end{array}$ & Gênero & \multicolumn{7}{c}{ Unidades de Ensino } \\
\hline 7 & $\mathrm{M}$ & 0 & 2 & 3 & 4 & 5 & 6 & \\
\hline & $\mathrm{F}$ & 0 & 0 & 7 & 0 & 0 & 0 & 7 \\
8 & $\mathrm{M}$ & 0 & 0 & 6 & 0 & 0 & 0 & 6 \\
& $\mathrm{~F}$ & 0 & 0 & 7 & 1 & 0 & 0 & 7 \\
9 & $\mathrm{M}$ & 0 & 0 & 4 & 2 & 0 & 0 & 8 \\
& $\mathrm{~F}$ & 0 & 0 & 5 & 2 & 0 & 0 & 6 \\
10 & $\mathrm{M}$ & 2 & 0 & 0 & 3 & 2 & 0 & 7 \\
& $\mathrm{~F}$ & 0 & 1 & 0 & 3 & 0 & 1 & 5 \\
11 & $\mathrm{M}$ & 4 & 6 & 0 & 4 & 4 & 9 & 27 \\
& $\mathrm{~F}$ & 5 & 4 & 0 & 3 & 5 & 8 & 25 \\
12 & $\mathrm{M}$ & 4 & 0 & 0 & 3 & 3 & 7 & 17 \\
& $\mathrm{~F}$ & 1 & 4 & 0 & 2 & 4 & 6 & 17 \\
13 & $\mathrm{M}$ & 6 & 5 & 0 & 4 & 5 & 2 & 22 \\
& $\mathrm{~F}$ & 6 & 4 & 0 & 5 & 5 & 2 & 22 \\
14 & $\mathrm{M}$ & 2 & 6 & 0 & 1 & 3 & 0 & 12 \\
& $\mathrm{~F}$ & 5 & 5 & 0 & 1 & 4 & 0 & 15 \\
Total & & 35 & 35 & 35 & 35 & 35 & 35 & 210 \\
\hline
\end{tabular}

1 = E.E. Prof. José de Mello Moraes

$2=$ E.E. João Guidotti

$3=$ E.E. Dr. Dario Brasil

$4=$ E.E. Augusto Melega

$5=$ E.E. Monsenhor Jeronymo Gallo

$6=$ E.E. Dr. Luiz Gonzaga de Campos Toledo

$M=$ Masculino

$\mathrm{F}=$ Feminino

\subsection{Obtenção e análise dos dados}

Antecedendo a etapa de coleta de dados, realizada junto aos alunos, nas escolas que integram a amostra, foram adotados procedimentos considerados fundamentais, envolvendo especialmente aspectos éticos.

Foi solicitada, oficialmente, por meio de carta (Anexo A) a listagem das escolas públicas do município de Piracicaba (Anexo B) e a prévia autorização do Diretor de Ensino de Piracicaba para a realização da pesquisa (Anexo C). Após a manifestação favorável do diretor de ensino, os documentos, 
incluindo um ofício registrando a recomendação da realização da pesquisa, foram entregues pessoalmente aos diretores das escolas (Anexo D).

Mediante a aquiescência dos diretores das unidades foram agendadas, de maneira que as atividades da pesquisa não interferissem nas rotinas das escolas, as datas para a realização das entrevistas com os alunos e também os testes da análise sensorial.

Os dados, junto aos alunos, foram coletados, no âmbito das unidades de ensino, durante os meses de maio e junho de 2001.

Para a identificação dos escolares, elaborou-se um sorteio, de forma alternada, utilizando-se a lista de chamada do professor, visando à obtenção de porcentagens similares de indivíduos do gênero masculino e do feminino e, contemplando também, a totalidade das faixas de idade entre 7 e 14 anos.

\subsubsection{Estado nutricional}

Para avaliar o estado nutricional dos alunos, foram tomadas as medidas antropométricas de peso e altura, utilizando-se balança com capacidade máxima de 120 quilogramas e sensibilidade de 1 quilograma. Os escolares, integrantes da amostra, foram pesados e medidos pela pesquisadora, e os dados registrados em formulário próprio (Anexo E).

Cada escolar selecionado foi posicionado no centro da balança, para o peso ficar distribuído igualmente entre os pés (descalços).

A altura foi obtida com os estudantes em posição ereta, pés (descalços) unidos e em paralelo. Utilizou-se uma fita métrica, afixada na parede, e esquadro, que foi firmemente apoiado sobre a cabeça, assegurandose que o aluno encontrava-se na posição correta para proceder-se à leitura e registro da altura obtida. 
A partir dos dados antropométricos dos escolares integrantes da pesquisa, foram calculados, utilizando-se o software Epi-Info (Dean et al., 2000) os indicadores antropométricos (escore $Z$ de altura para idade - ZAl e escore $Z$ de peso para idade - ZPI).

Três intervalos de escores $Z$ foram distinguidos: menor que -2 (indicador de comprometimento do estado nutricional), de -2 a menos que -1 , e pelo menos igual a-1 (indicador de eutrofia).

É importante ressaltar que o referido software impõe limitações para o cálculo e análise do índice de peso para altura - ZPA, somente sendo calculado para indivíduos do sexo masculino até 138 meses (11,5 anos) de idade e com menos de 145 centímetros e para indivíduos do sexo feminino até 120 meses (10 anos) e com menos de 137 centímetros (Silva et al.,1999a). Por isso, julgou-se pertinente não envolver o indicador ZPA nas análises da presente pesquisa.

Também foi analisada a distribuição dos percentis do Índice de Massa Corporal - IMC, calculado pela relação entre o peso corporal $(\mathrm{kg})$ e estatura $(m)$ ao quadrado. De acordo com a recomendação da Organização Mundial da Saúde (WHO, 1995) adotou-se os seguintes níveis críticos: IMC<15은 Percentil (baixo peso), 15을 Percentil $\leq \mathrm{IMC}<85^{\circ}$ Percentil (eutrofia) e IMC $\geq 85^{\circ}$ Percentil (sobrepeso) e o padrão de referência preconizado, também, pelo Center for Disease Control and Prevention, do National Center for Health Statistics - NCHS (2002).

\subsubsection{Consumo alimentar}

As informações relativas ao consumo alimentar dos escolares foram obtidas por meio da adoção de dois tipos de questionários: o de Freqüência Alimentar e o Recordatório 24 horas. Foram considerados os alimentos consumidos na escola e, também, fora dela. 
Os dados sobre o consumo de alimentos foram obtidos por meio de entrevistas realizadas pela autora, adotando-se o método Recordatório 24 horas (Anexo F). Os alimentos foram registrados, em medidas caseiras, adotando-se formulário próprio, atentando-se para a discriminação das refeições (café da manhã, lanche da manhã, almoço, lanche da tarde ou merenda, jantar e lanche noturno), horário e local de consumo dos alimentos (Lerner, 1994; Mahan \& Arlin, 1995 e Silva, 1998a). Com o objetivo de efetuar, de maneira apropriada o registro da quantidade dos alimentos consumidos foi utilizado um Modelo de Medidas de Utensílios Caseiros (Anexo G).

O método Recordatório 24 horas, baseia-se na definição e quantificação de todos os alimentos e bebidas que foram consumidas no período anterior à entrevista (24 horas) ou geralmente, o dia anterior à obtenção dos dados.

Tendo por base a metodologia das pesquisas nacionais $\mathrm{e}$ internacionais, pode se afirmar que o método Recordatório 24 horas tem sido o instrumento mais utilizado para a avaliação da ingestão de alimentos (nutrientes) pelos indivíduos. Grandes pesquisas como a do Estudo Multicêntrico (Galeazzi et al., 1997) e o "Saúde e nutrição das crianças de São Paulo" (Monteiro, 1988) adotaram o Recordatório 24 horas para obter as informações dietéticas (Villar, 2001).

Para o cálculo e as análises do conteúdo de energia e nutrientes utilizou-se o software Virtual Nutri (Philippi et al., 1996).

As informações referentes às práticas alimentares, consumo de hortaliças e estilo de vida dos escolares foram obtidas por meio da utilização de um questionário (Anexo H) composto por 21 questões do tipo objetivas e dissertativas.

O consumo alimentar dos alunos foi investigado utilizando-se 0 questionário de freqüência alimentar, considerando-se os alimentos consumidos no domicílio e fora dele. O objetivo da adoção deste instrumento é obter a quantidade dos alimentos ou grupos de alimentos que são consumidos durante 
um determinado período de tempo, ou seja, obter dados sobre o consumo habitual. Consiste em uma lista de alimentos com uma seção de respostas sobre a freqüência de consumo de cada alimento. $O$ método possibilita a obtenção de informações qualitativas (Cintra et al., 1997 e Villar, 2001).

Para a implementação da presente pesquisa, adotou-se 0 questionário de freqüência alimentar que registrava uma extensa lista de alimentos e um espaço, no qual o escolar assinalou com um " $X$ " o espaço correspondente àfreqüência do consumo de cada alimento ou bebida.

De acordo com Villar (2001), o questionário de freqüência alimentar é utilizado em numerosos estudos prospectivos internacionais, com a vantagem de ser um método prático e ainda possibilitar a avaliação da ingestão dietética. É reconhecido também por seu emprego ser bastante apropriado para a obtenção de dados em pesquisas epidemiológicas que visam relacionar a dieta inadequada com uma maior probabilidade de desenvolvimento de doenças crônicas.

Os questionários da presente pesquisa foram pré-testados e padronizados, antes de serem submetidos, individualmente aos alunos integrantes da amostra. Vale destacar que os escolares receberam prévias instruções sobre os procedimentos a serem adotados para o registro das informações.

Aos escolares com idade pelo menos igual a 11 anos foram fornecidas instruções para que preenchessem os questionários, na presença da autora para que fosse possível fornecer os esclarecimentos, quando necessários. Especificamente quanto aos alunos de 7 a 10 anos, optou-se pela entrevista, ou seja, os alunos responderam oralmente as questões registradas no instrumento e apresentadas pela autora.

Utilizando-se o software Fox Base (Zarpellon Junior \& Trevisan, 1991), com o objetivo de sistematizar as informações registradas nos questionários dos escolares foram construídos bancos de dados. As análises 
estatísticas foram elaboradas utilizando-se os recursos do software Statistical Analysis System - SAS (1998).

Nesta pesquisa pretendeu-se também conhecer a qualidade da dieta dos escolares por meio da identificação da participação dos macronutrientes (carboidratos, proteínas e lipídios) no Valor Energético Total VET.

Para a classificação das dietas, adotou-se os seguintes intervalos de participação dos macronutrientes: $45 \%$ a $60 \%$ (carboidratos); $10 \%$ a $30 \%$ (proteínas) e 25\% a 35\% (lipídios) (National Academy of Sciences, 2002).

Vale enfatizar que os intervalos de participação dos macronutrientes foram preconizados pelas Dietary Reference Intakes - DRIs, especialmente para indivíduos com idade entre 4 e 18 anos (National Academy of Sciences, 2002).

\subsubsection{Informações socioeconômicas da família}

Para melhor caracterizar a população alvo da presente pesquisa, foram coletadas por meio de formulários contendo 22 questões do tipo objetivas e dissertativas, informações relativas às características socioeconômicas dos escolares (Anexo I). Os formulários foram encaminhados aos pais (ou responsáveis), juntamente com um documento, onde estavam registrados os propósitos da pesquisa (Anexo J).

\subsection{Análise sensorial das hortaliças minimamente processadas}

Visando conhecer a opinião dos escolares sobre as hortaliças minimamente processadas (cenoura e vagem), realizou-se teste de análise sensorial. Os referidos alimentos foram adquiridos em supermercado do município de Piracicaba e posteriormente, apresentados aos alunos na forma 
de salada temperados somente com limão e sal. Os vegetais foram cozidos e repartidos em porções com quantidades padronizadas.

Utilizou-se cenoura e vagem por serem os vegetais que tradicionalmente são registrados nos cardápios elaborados e disponibilizados nas unidades de ensino, pelos responsáveis pelo Programa de Merenda Escolar da rede de ensino de Piracicaba (Anexo K).

Visando a avaliação da aceitabilidade pelos escolares, das preparações elaboradas com as hortaliças (que sofreram o processamento mínimo) foi adotada uma escala hedônica facial de três pontos, em ordem decrescente de acordo com as expressões caracterizadas pelas faces desenhadas, que representaram as situações de: "gostar muito", ou "gostar pouco" ou "não gostar".

A aceitação de um alimento é uma experiência que se caracteriza por uma atitude positiva, medida por meio da análise do consumo real de um alimento e expressa o grau de gostar ou não gostar do alimento (Teixeira et al., 1987).

De acordo com Oliveira (1997), a metodologia para testar a preferência e a aceitação dos consumidores por determinados produtos foi criada por Peryam em 1952, para indicar a atitude do provador em relação ao produto, identificando o ponto que melhor descreve sua percepção sobre o alimento. As escalas hedônicas são muito utilizadas pela indústria alimentícia, não havendo necessidade do provador receber prévio treinamento para participar dos testes.

A escala hedônica facial é uma variação da escala hedônica tradicional, sendo também conhecida como escala de avaliação do sorriso (smile rating scale). Neste método, as expressões faciais são registradas visando possibilitar ao provador, a opção que melhor traduza a sua opinião, ou seja, o grau de prazer ou desprazer experimentado, quando este avalia sensorialmente um produto. Vale informar que a referida escala pode conter 3 , 5, 7 e 9 expressões (Teixeira et al., 1987). 
Ainda de acordo com Teixeira et al. (1987), diversos tipos de escalas hedônicas faciais são utilizadas com êxito para diferentes objetivos (como exemplos a aceitabilidade de produtos da merenda escolar e testes promocionais de alimentos, registrados em supermercados).

A escala hedônica é o teste de aceitabilidade mais usado para avaliar a aceitabilidade de um produto. Este tipo de teste pode ser considerado como uma das mais importantes etapas da Análise Sensorial. Ainda representa o somatório de todas as percepções sensoriais e expressa o julgamento, por parte do consumidor, no tocante àqualidade do produto (Verruma, 2000).

$\mathrm{Na}$ avaliação de cardápios é possível também, entre outras metodologias, a utilização de: "Estimativa visual das sobras em cada prato", "Medidas de sobras agregadas" e "Teste de escala hedônica estruturada" (Brandão, 2000).

Vale registrar que Oliveira (1997), implementando pesquisas envolvendo amostra de escolares (7 a 9 anos de idade), utilizou a escala hedônica facial de 3 pontos, tendo como argumento o fato da dificuldade enfrentada (manifestada durante o pré-teste) pelos alunos da rede pública, para o registro da opinião, quando o instrumento envolvia número superior a 3 pontos.

Nesta pesquisa, para cada um dos alunos integrantes da amostra foi fornecido um recipiente contendo as hortaliças, para degustação e, também, uma ficha do teste (Anexo $L$ ), para que fosse preenchida individualmente. $A$ totalidade dessas informações foi obtidas no âmbito das unidades escolares.

\subsection{Análises estatísticas}

Utilizando-se os recursos do software Statistical Analysis System SAS (1998), foram elaboradas as análises estatísticas.

As análises visando identificar a existência de associação entre as variáveis consideradas, envolvem testes de qui-quadrado e quando pertinente, 
o qui-quadrado de tendência linear ou qui-quadrado de Mantel-Haenszel - MH (1959). Os resultados dos referidos testes acompanham as tabelas de contingência, apresentadas na seção de resultados.

Vale lembrar que o qui-quadrado comum destina-se a captar qualquer tipo de relação entre duas variáveis utilizadas na elaboração das tabelas de contingência. Por outro lado, o qui-quadrado de tendência linear destina-se a detectar a existência de tendência de crescimento ou diminuição das variáveis de uma função do nível da outra variável considerada. Sendo um teste com uma finalidade específica o qui-quadrado de tendência linear é mais poderoso que o qui-quadrado comum (Silva, 1996). 


\section{RESULTADOS E DISCUSSÃo}

\subsection{Estado nutricional}

Com o objetivo de analisar o estado nutricional dos alunos, tendo como base as medidas de peso $(\mathrm{kg})$ e altura $(\mathrm{cm})$, foram elaboradas análises envolvendo a distribuição dos percentis do Índice de Massa Corporal - IMC. Os resultados são apresentados, a seguir (Tabelas 3, 4 e 5).

Tabela 3. Distribuição dos escolares em categorias do estado nutricional, com base nos percentis do Índice de Massa Corporal - IMC e gênero. Piracicaba, 2001.

\begin{tabular}{|c|c|c|c|c|c|c|}
\hline \multirow{3}{*}{$\begin{array}{l}\text { Percentis } \\
\text { do IMC }\end{array}$} & \multicolumn{4}{|c|}{ Gênero } & \multirow{2}{*}{\multicolumn{2}{|c|}{ Total }} \\
\hline & \multicolumn{2}{|c|}{ Feminino } & \multicolumn{2}{|c|}{ Masculino } & & \\
\hline & $\mathrm{n}^{0}$ & $\%$ & $\mathrm{n}^{0}$ & $\%$ & $\mathrm{n}^{\circ}$ & $\%$ \\
\hline 3 & 1 & 0,5 & 3 & 1,4 & 4 & 1,9 \\
\hline 5 & 2 & 1,0 & 1 & 0,5 & 3 & 1,5 \\
\hline 10 & 6 & 2,8 & 8 & 3,8 & 14 & 6,6 \\
\hline 15 & 0 & 0 & 0 & 0 & 0 & 0 \\
\hline 25 & 15 & 7,1 & 15 & 7,1 & 30 & 14,2 \\
\hline 50 & 22 & 10,5 & 26 & 12,4 & 48 & 22,9 \\
\hline 75 & 22 & 10,5 & 18 & 8,6 & 40 & 19,1 \\
\hline 85 & 7 & 3,3 & 10 & 4,8 & 17 & 8,1 \\
\hline 90 & 10 & 4,8 & 11 & 5,2 & 21 & 10,0 \\
\hline 95 & 9 & 4,3 & 4 & 1,9 & 13 & 6,2 \\
\hline 97 & 11 & 5,2 & 9 & 4,3 & 20 & 9,5 \\
\hline Total & 105 & 50,0 & 105 & 50,0 & 210 & 100,0 \\
\hline
\end{tabular}


Ao examinar os dados da Tabela 3, verifica-se que 1,9\% dos escolares foram classificados no primeiro intervalo (3ํㅜㄹ Percentil), sendo que 0 valor esperado seria de $3 \%$. Trata-se, portanto de prevalência de baixo peso, muito inferior à esperada. É válido destacar, também, a diferença observada, quando se considera a situação dos escolares, de acordo com o gênero $(1,4 \%$ e $0,5 \%$ de $I M C=3^{\circ} \mathrm{P}$, para meninos e meninas, respectivamente).

Vale notar que $6,6 \%$ dos alunos foram classificados no $10^{\circ}$ Percentil, sendo que o esperado seria de $10 \%$. Quando se analisa esse percentual entre meninos e meninas, nota-se que $2,8 \%$ das meninas e $3,8 \%$ dos meninos foram classificados no $10^{\circ}$ Percentil.

Em situação oposta, ou seja, quando se analisa as proporções de indivíduos com indicativo de sobrepeso e obesidade, verifica-se que $6,2 \%$ dos alunos encontram-se no 95 Percentil, enquanto que o esperado seria de $5 \%$. Ao se examinar os resultados de acordo com o gênero, nota-se que $4,3 \%$ das meninas e 1,9\% dos meninos, foram classificados no $95^{\circ}$ Percentil. $O$ percentual de meninas, nessa condição, superou (cerca de 2,3 vezes) a proporção dos meninos.

Um dado preocupante refere-se ao grupamento de escolares $(9,5 \%)$ que foram classificados no $97^{\circ}$ Percentil, quando o esperado, deveria ser $3 \%$. Nota-se portanto, cerca de proporção três vezes maior do que a observada em populações consideradas de referência.

Uma pesquisa envolvendo 92 escolares com idade entre 11 a 17 anos mostrou que os percentuais de sobrepeso encontrados, para os escolares do gênero masculino foram $4,6 \%$ e, para o grupo do gênero feminino, $16,3 \%$ (Albano, 2000).

Visando conhecer o estado nutricional dos escolares, distinguindoos, de acordo com faixas de IMC e gênero, foi elaborada a Tabela 4, mostrada a seguir. 
Tabela 4. Distribuição dos escolares em categorias do estado nutricional com base no Índice de Massa Corporal - IMC e gênero. Piracicaba, 2001.

\begin{tabular}{crrrrrr}
\hline & \multicolumn{3}{c}{ Gênero } & & \multicolumn{2}{c}{ Total } \\
Categorias do & \multicolumn{2}{c}{ Feminino } & \multicolumn{2}{c}{ Masculino } & \multicolumn{2}{c}{$\%$} \\
estado nutricional & \multicolumn{1}{c}{$\mathrm{n}^{\circ}$} & \multicolumn{1}{c}{$\%$} & \multicolumn{1}{c}{$\mathrm{n}^{\circ}$} & \multicolumn{1}{c}{$\%$} & \multicolumn{1}{c}{$\mathrm{n}^{\circ}$} & \multicolumn{1}{c}{$\%$} \\
\hline $\mathrm{IMC}<15^{\circ} \mathrm{P}$ & 9 & 4,3 & 12 & 5,7 & 21 & {$[10,0]$} \\
$15^{\circ} \mathrm{P} \leq \mathrm{IMC}<85^{\circ} \mathrm{P}$ & 59 & 28,1 & 59 & 28,1 & 118 & {$[56,2]$} \\
$\mathrm{IMC} \geq 85^{\circ} \mathrm{P}$ & 37 & 17,6 & 34 & 16,2 & 71 & {$[33,8]$} \\
Total & 105 & {$[50,0]$} & 105 & {$[50,0]$} & 210 & {$[100,0]$} \\
\hline
\end{tabular}

Nota: os números entre colchetes significam os percentuais em relação a 210 escolares.

Tendo por base os dados da Tabela 4, verifica-se que, a prevalência de sobrepeso (IMC $\geq 85^{\circ} \mathrm{P}$ ) observada foi de $33,8 \%$. Ao analisar as informações relativas æ̀ meninas, pode-se constatar que o valor $(17,6 \%)$ supera ligeiramente a proporção de 16,2\% encontrada para os meninos.

Nota-se que o valor de prevalência de sobrepeso $(33,8 \%)$ se revelou 18,8 pontos percentuais acima do esperado (15\%). Dessa forma, a proporção observada se mostrou elevada e o resultado é motivo de preocupação, devido à obesidade trazer, invariavelmente, como conseqüência sérios problemas para a saúde dos indivíduos.

Quando se considera o grupamento de escolares com indicativo de baixo peso (IMC $\left.<15^{\circ} \mathrm{P}\right)$ o resultado encontrado, na presente pesquisa, é bastante satisfatório, pois somente $1,9 \%$ podem ser considerados magros.

Vale lembrar que os dados da presente dissertação foram obtidos durante $\mathrm{o}$ ano de 2001. Pesquisa realizada um ano antes, ou seja, em 2000, envolvendo 578 adolescentes da rede pública de Piracicaba, revelou que 4,8\% dos alunos apresentaram baixo peso, 2,21\% foram classificados com sobrepeso e $10 \%$, identificados como obesos (Caroba, 2002).

Sturion (2002) verificou que entre os 2.678 escolares pertencentes a dez municípios de cinco regiões geográficas do país, 3,5\% foram classificados como tendo baixo peso e 6,4\% eram obesos. Os resultados estão longe de serem homogêneos, ou seja, a prevalência de obesidade, é 
especialmente distinta quando se classifica os grupos de escolares, de acordo com as regiões geográficas de origem.

Um trabalho realizado por Carvalho et al. (2001), envolvendo amostra de 334 estudantes com idade entre 10 a 19 anos, da rede particular de ensino em Teresina, revelou que a prevalência de sobrepeso (IMC $\geq 85^{\circ} \mathrm{P}$ ) situou-se em torno de $20 \%$. Os maiores percentuais referentes ao sobrepeso foram encontrados entre a população masculina (24,8\%), sendo que a situação verificada para a população feminina revelou uma proporção menor (15,5\%).

Ainda de acordo com os referidos autores, a obesidade na infância e na adolescência tem como conseqüência uma maior possibilidade de sua manutenção na idade adulta.

A obesidade, como problema de saúde pública, assim como fator indutor de comportamentos individuais e sociais é um assunto que atualmente tem merecido muita atenção dos pesquisadores. Sua elevada prevalência reforça, em nossos dias, toda uma popularização banalizada da própria obesidade. Ao obeso e aos que têm medo de se tornarem obesos, dirigi-se toda uma indústria de alimentos, equipamentos, vestuário, que tenta reordenar hábitos, independentemente da apreensão da causalidade da obesidade (Fonseca et al., 1998).

Segundo Gigante et al. (1997), entre os anos de 1974 e 1989, no Brasil, constatou-se que a proporção de pessoas com excesso de peso aumentou de $21 \%$ para $32 \%$. Ao se comparar os dados obtidos para as distintas regiões do país, verificou-se que o Sul apresentou os maiores contingentes de indivíduos obesos.

Ainda de acordo com os referidos autores, a evolução da ocorrência da obesidade no período considerado, em relação ao gênero, dobrou entre os homens (de $2,4 \%$ para $4,8 \%$ ), enquanto que entre a população feminina o aumento da obesidade também foi expressivo (7\% para $12 \%)$.

Estatísticas mostram que $80 \%$ dos filhos, com ambos os pais obesos, também são classificados como obesos, enquanto praticamente cerca 
da metade (45\%) dos filhos com um dos pais obesos, são obesos e, menor proporção, ou seja, $18 \%$ dos filhos cujos pais são magros, são diagnosticados como obesos (Salazar, 1996).

O excesso de peso configura-se como importante problema social, devido à discriminação das pessoas obesas, pela sociedade, que valoriza a imagem dos indivíduos magros (Salazar, 1996). Ainda de acordo o autor, conseqüentemente, as crianças e adolescentes obesos são quase sempre discriminados nos ambientes escolares, grupos e atividades sociais, gerando um círculo vicioso de baixa auto-estima, depressão e, como conseqüência, conduzindo ao excesso de alimentação como consolo e, resultando em ganho de peso.

Segundo Salazar (1996), as meninas obesas geralmente apresentam depressão, e esta pode ser associada a um maior sedentarismo. Dentre os fatores sociais descreve-se o referido comportamento como resultado da automatização e busca de conforto.

Ao lado dos problemas de saúde, a obesidade traz transtornos estéticos aos indivíduos, além das naturais dificuldades que enfrentam no dia-adia, como subir uma escada, passar por uma roleta de ônibus ou entrar em veículos de transporte coletivo como é o caso, por exemplo, do metrô. O obeso é visto como uma figura exótica, o que pode provocar problemas psíquicos. A obsessão com a redução do peso causa distúrbios neurológicos como a anorexia, muito comum em profissionais que atuam na área da moda, como é o caso, por exemplo, das modelos. Os obesos têm também expectativa de vida menor, provocada pelo surgimento de doenças cardíacas e do diabetes, por exemplo. São comuns também as lesões na coluna e nas articulações, principalmente comprometendo a mobilidade dos joelhos (Salazar, 1996).

Gigante et al. (1997) também registram que a obesidade é um fator de risco para hipertensão arterial, hipercolesterolemia, diabetes, doenças cardiovasculares e algumas formas de câncer. 
De acordo com Fisberg (1995) a obesidade na infância e adolescência pode trazer a possibilidade de sua preservação na vida adulta. Note-se que, para os indivíduos mais jovens ou com menor idade, a morbidade não é observada com freqüência e também não é considerada como problema. No entanto, na fase adulta a situação é de risco e leva a um aumento da mortalidade por freqüente associação com doença arteriosclerótica, hipertensão e alterações metabólicas.

Os principais riscos para a saúde da criança, ocasionados pelo excesso de peso, são: a elevação dos triglicerídios e do colesterol, alterações ortopédicas, dermatológicas e respiratórias. $\mathrm{Na}$ maioria dos casos, as alterações metabólicas são mais evidentes na fase adulta (Fisberg, 1995).

$\mathrm{Na}$ presente pesquisa julgou-se pertinente analisar a associação entre situação socioeconômica (captada pela renda familiar per capita) e o estado nutricional dos alunos. A seguir são apresentados os resultados obtidos, tendo por base três estratos de renda familiar per capita e o estado nutricional atual (Tabela 5).

Tabela 5. Distribuição dos escolares de acordo com o estado nutricional, com base no Índice de Massa Corporal - IMC e estratos de renda familiar per capita. Piracicaba, 2001.

\begin{tabular}{|c|c|c|c|c|c|c|c|c|}
\hline \multirow{3}{*}{$\begin{array}{l}\text { Estrato de renda } \\
\text { familiar per capita } \\
\text { (em reais) }\end{array}$} & \multirow{2}{*}{\multicolumn{2}{|c|}{ Observações }} & \multicolumn{6}{|c|}{ Categorias de Estado Nutricional } \\
\hline & & & \multicolumn{2}{|c|}{$\mathrm{IMC}<15^{\circ} \mathrm{P}$} & \multicolumn{2}{|c|}{$\begin{array}{c}15^{\circ} \mathrm{P} \leq \mathrm{IMC}< \\
85^{\circ} \mathrm{P}\end{array}$} & \multicolumn{2}{|c|}{$\mathrm{IMC} \geq 85^{\circ} \mathrm{P}$} \\
\hline & $\mathrm{n}^{\mathrm{o}}$ & $\%$ & $\mathrm{n}^{\mathrm{o}}$ & $\%$ & $\mathrm{n}^{\circ}$ & $\%$ & $\mathrm{n}^{\mathrm{o}}$ & $\%$ \\
\hline$\leq 200,00$ & 118 & 64,8 & 11 & 9,3 & 66 & 55,9 & 41 & 34,8 \\
\hline $200,00-400,00$ & 52 & 28,6 & 4 & 7,7 & 31 & 59,6 & 17 & 32,7 \\
\hline$>400,00$ & 12 & 6,6 & 3 & 25,0 & 6 & 50,0 & 3 & 25,0 \\
\hline TOTAL & 182 & 100,0 & 18 & $(9,9)$ & 103 & $(56,6)$ & 61 & $(33,5)$ \\
\hline
\end{tabular}

$\chi^{2}=3,57$, com 4 graus de liberdade, não-significativo.

$\chi^{2}(\mathrm{MH})=0,95$, com 1 grau de liberdade, não-significativo.

Nota :- os números entre parênteses são os percentuais em relação ao total observado na linha.

- análises elaboradas tendo por base o número de observações $(n=182)$ para as quais dispunha-se de informações válidas. 
Ao examinar os dados da Tabela 5 é possível verificar que entre os escolares com menor renda (inferior a $\mathrm{R} \$ 200,00$ ), apenas $9,3 \%$ revelaram IMC inferior $15^{\circ} \mathrm{P}$ (indicativo de baixo peso), enquanto o esperado é $15 \%$. Inversamente, quando se considera o grupo com indicativo de sobrepeso, também pertencente ao grupo mais pobre, $34,8 \%$ de escolares apresentaram $I M C \geq 85^{\circ} \mathrm{P}$, ou seja, proporção muito superior à esperada (15\%) quando se considera a população de referência.

Atentando para os resultados obtidos para os escolares com renda familiar per capita acima de $\mathrm{R} \$ 400,00$ observa-se que $25 \%$ apresentaram indicativo de baixo peso, proporção idêntica à encontrada quando se considera o nível crítico do $85^{\circ} \mathrm{P}$, para identificação da prevalência de sobrepeso.

No entanto, os testes que acompanham a referida tabela não revelaram associação estatisticamente significativa, entre as variáveis consideradas.

Nesta pesquisa, julgou-se pertinente também analisar a situação dos escolares, tendo por base os indicadores de escore $Z$ de altura para idade - ZAl e escore $Z$ de peso para idade - ZPI, e os estratos de renda familiar per capita (Tabelas 6 e 7 ). 
Tabela 6. Distribuição dos escolares de acordo com o estado nutricional, com base no escore $Z$ de altura para idade - ZAl e estratos de renda familiar per capita. Piracicaba, 2001.

\begin{tabular}{|c|c|c|c|c|c|c|c|c|}
\hline \multirow{2}{*}{$\begin{array}{c}\text { Estratos de renda } \\
\text { familiar per capita } \\
\text { (em reais) }\end{array}$} & \multicolumn{2}{|c|}{ Observações } & \multicolumn{6}{|c|}{$\begin{array}{c}\text { Estado Nutricional } \\
-2<7 A l<-1\end{array}$} \\
\hline & $\mathrm{n}^{\circ}$ & $\%$ & $n^{\circ}$ & $\%$ & $\mathrm{n}^{\circ}$ & $\%$ & $\mathrm{n}^{\circ}$ & $\%$ \\
\hline$\leq 200,00$ & 118 & 64,8 & 2 & $\begin{array}{r}1,7 \\
(100,0)\end{array}$ & 20 & $\begin{array}{l}17,0 \\
(80)\end{array}$ & 96 & $\begin{array}{r}81,3 \\
(62,0)\end{array}$ \\
\hline $200,00-400,00$ & 52 & 28,6 & 0 & $\begin{array}{r}0,0 \\
(0,0)\end{array}$ & 5 & $\begin{array}{r}9,6 \\
(20,0)\end{array}$ & 47 & $\begin{array}{r}90,4 \\
(30,3)\end{array}$ \\
\hline$>400,00$ & 12 & 6,6 & 0 & $\begin{array}{r}0,0 \\
(0,0)\end{array}$ & 0 & $\begin{array}{r}0,0 \\
(0,0)\end{array}$ & 12 & $\begin{array}{r}100,0 \\
(7,7)\end{array}$ \\
\hline TOTAL & 182 & 100,0 & 2 & {$[1,1]$} & 25 & {$[13,7]$} & 155 & {$[85,2]$} \\
\hline
\end{tabular}

$\chi^{2}=4,90$, com 4 graus de liberdade, não-significativo.

$\chi^{2}(\mathrm{MH})=4,72$, com 1 grau de liberdade, não-significativo a $5 \%$.

Nota: - os números entre parênteses são os percentuais em relação ao total observado na coluna.

- os números entre colchetes são os percentuais em relação ao total observado na linha.

- análises elaboradas tendo por base o número de observações $(n=182)$ para as quais dispunha-se de informações válidas.

Analisando os dados da Tabela 6 verifica-se que, de forma geral apenas $1,1 \%$ dos escolares foram classificados com ZAI $<-2$ (indicativo de déficit de altura). Trata-se de proporções muito inferiores à esperada (aproximadamente de 2,0\%), quando se considera grupos de referência.

Destaca-se, também, que ao examinar os estratos de renda familiar intermediária $(R \$ 200,00-1 R \$ 400,00)$ e o grupo com rendimento mais elevado (> R \$400,00), não é possível encontrar escolares com ZAI $<-2$.

$\mathrm{Na}$ Tabela 7 são apresentados os resultados obtidos, quando se considera a associação entre o indicador ZPI e a renda familiar per capita. 
Tabela 7. Distribuição dos escolares de acordo com o estado nutricional, com base no escore $Z$ de peso para idade - ZPI e estratos de renda familiar per capita. Piracicaba, 2001.

\begin{tabular}{|c|c|c|c|c|c|c|c|c|}
\hline \multirow{2}{*}{$\begin{array}{l}\text { Estratos de renda } \\
\text { familiar per capita } \\
\text { (em reais) }\end{array}$} & \multicolumn{2}{|c|}{ Observações } & \multicolumn{6}{|c|}{ Estado Nutricional } \\
\hline & $\mathrm{n}^{\circ}$ & $\%$ & $\mathrm{n}^{0}$ & $\%$ & $\mathrm{n}^{\mathrm{o}}$ & $\%$ & $\mathrm{n}^{0}$ & $\%$ \\
\hline$\leq 200,00$ & 118 & 64,8 & 1 & $\begin{array}{r}0,9 \\
(100,0)\end{array}$ & 12 & $\begin{array}{r}10,1 \\
(63,2)\end{array}$ & 105 & $\begin{array}{r}89,0 \\
(64,8)\end{array}$ \\
\hline $200,00-\mid 400,00$ & 52 & 28,6 & 0 & $\begin{array}{r}0,0 \\
(0,0)\end{array}$ & 5 & $\begin{array}{r}9,6 \\
(26,3)\end{array}$ & 47 & $\begin{array}{r}90,4 \\
(29,0)\end{array}$ \\
\hline$>400,00$ & 12 & 6,6 & 0 & $\begin{array}{r}0,0 \\
(0,0)\end{array}$ & 2 & $\begin{array}{r}16,6 \\
(10,5)\end{array}$ & 10 & $\begin{array}{l}83,4 \\
(6,2)\end{array}$ \\
\hline TOTAL & 182 & 100,0 & 1 & {$[0,5]$} & 19 & {$[10,4]$} & 162 & {$[89,1]$} \\
\hline
\end{tabular}

$\chi^{2}=1,09$, com 4 graus de liberdade, não-significativo.

$\chi^{2}(\mathrm{MH})=0,007$, com 1 grau de liberdade, não-significativo a $5 \%$.

Nota: - os números entre parênteses são os percentuais em relação ao total observado na coluna.

- os números entre colchetes são os percentuais em relação ao total observado na linha.

- análises elaboradas tendo por base o número de observações $(n=182)$ para as quais dispunha-se de informações válidas.

Da análise dos dados da Tabela 7 depreende-se que, de forma geral, a proporção de escolares com ZPI $<-2$ é extremamente reduzida $(0,5 \%)$, portanto, considerada também, muito inferior à esperada (aproximadamente 2,0\%).

Quando se analisa as proporções de alunos com indicativo de eutrofia (ZPI $\geq-1$ ) a proporção alcança $89,1 \%$, considerada superior à esperada.

Vale ressaltar, também, a homogeneidade da proporção de eutróficos, quando se considera os três estratos de renda familiar per capita.

No que tange os resultados relativos à situação nutricional pregressa, pode se afirmar que os escolares, integrantes da pesquisa revelaram desempenho bastante satisfatório, especialmente quando se compara esses dados com os resultados obtidos por Caroba (2002). 
Vale destacar que Caroba (2002) analisou a situação nutricional de amostra $(n=578)$ de alunos, com idade entre 10 e 16 anos, encontrando $4,0 \%$ e $3,1 \%$ de indivíduos, com $\mathrm{ZAI}<-2$ e $\mathrm{ZPI}<-2$, respectivamente.

A seguir, apresenta-se os resultados envolvendo o estado nutricional dos escolares e a escolaridade materna (Tabela 8).

Tabela 8. Distribuição dos escolares de acordo com o estado nutricional, com base no Índice de Massa Corporal - IMC e a escolaridade da mãe. Piracicaba, 2001.

\begin{tabular}{|c|c|c|c|c|c|c|c|c|}
\hline \multirow{3}{*}{$\begin{array}{l}\text { Categorias de } \\
\text { estado nutricional }\end{array}$} & \multirow{2}{*}{\multicolumn{2}{|c|}{ Escolares }} & \multicolumn{6}{|c|}{ Escolaridade da mãe (anos de estudo) } \\
\hline & & & & -14 & & & & \\
\hline & $\mathrm{n}^{\circ}$ & $\%$ & $\mathrm{n}^{\circ}$ & $\%$ & $\mathrm{n}^{\circ}$ & $\%$ & $\mathrm{n}^{0}$ & $\%$ \\
\hline $\mathrm{IMC}<15^{\circ} \mathrm{P}$ & 28 & 14,4 & 15 & $\begin{array}{r}53,6 \\
(21,4)\end{array}$ & 4 & $\begin{array}{l}14,3 \\
(5,6)\end{array}$ & 9 & $\begin{array}{r}32,1 \\
(17,3)\end{array}$ \\
\hline $15^{\circ} \mathrm{P} \leq \mathrm{IMC}<85^{\circ} \mathrm{P}$ & 115 & 59,3 & 35 & $\begin{array}{r}30,4 \\
(50,0)\end{array}$ & 53 & $\begin{array}{r}46,1 \\
(73,6)\end{array}$ & 27 & $\begin{array}{r}23,5 \\
(51,9)\end{array}$ \\
\hline $\mathrm{IMC} \geq 85^{\circ} \mathrm{P}$ & 51 & 26,3 & 20 & $\begin{array}{r}39,2 \\
(28,6)\end{array}$ & 15 & $\begin{array}{r}29,4 \\
(20,8)\end{array}$ & 16 & $\begin{array}{r}31,4 \\
(30,8)\end{array}$ \\
\hline TOTAL & 194 & 100,0 & 70 & {$[36,1]$} & 72 & {$[37,1]$} & 52 & {$[26,8]$} \\
\hline
\end{tabular}

$\chi^{2}=11,94$, com 4 graus de liberdade, significativo a $5 \%$.

$\chi^{2}(\mathrm{MH})=0,36$, com 1 grau de liberdade, não-significativo.

Nota : As análises foram elaboradas, tendo por base as respostas válidas obtidas para 194 escolares.

- os números entre colchetes são os percentuais relativos ao total observado na linha

- os números entre parênteses são os percentuais em relação ao total observado na coluna.

Atentando para o grupo de escolares classificados com IMC $<15^{\circ} \mathrm{P}$ (baixo peso) verifica-se que a maior parte deles $(53,6 \%)$ são filhos de mães com menor escolaridade (máximo de 4 anos de estudo).

Inversamente, quando se analisa os resultados obtidos para os alunos com IMC $\geq 85^{\circ} \mathrm{P}$ (sobrepeso) é notória a maior prevalência $(30,8 \%)$ de sobrepeso, entre os alunos, cujas mães possuíam escolaridade de no máximo 4 anos. 
O teste de qui-quadrado comum confirma a existência de associação entre o estado nutricional dos alunos e o nível de escolaridade da mãe.

$\mathrm{Na}$ seqüência, apresenta-se os resultados envolvendo o estado nutricional dos escolares e a atividade profissional das mães (Tabela 9).

Tabela 9. Distribuição dos escolares de acordo com o estado nutricional, com base no Índice de Massa Corporal - IMC e a atividade profissional da mãe. Piracicaba, 2001.

\begin{tabular}{|c|c|c|c|c|c|c|c|c|}
\hline \multirow{3}{*}{$\begin{array}{l}\text { Categorias de } \\
\text { estado nutricional }\end{array}$} & & & \multicolumn{6}{|c|}{$\begin{array}{l}\text { Atividade profissional da mãe } \\
\text { (fora do domicílio) }\end{array}$} \\
\hline & \multicolumn{2}{|c|}{ Escolares } & \multicolumn{2}{|c|}{ SIM } & \multicolumn{2}{|c|}{ NÃO } & \multicolumn{2}{|c|}{$\begin{array}{l}\text { Desemprego } \\
\text { recente }\end{array}$} \\
\hline & $\mathrm{n}^{0}$ & $\%$ & $\mathrm{n}^{\circ}$ & $\%$ & $\mathrm{n}^{0}$ & $\%$ & $\mathrm{n}^{\circ}$ & $\%$ \\
\hline $\mathrm{IMC}<15^{\circ} \mathrm{P}$ & 27 & 13,7 & 12 & $\begin{array}{r}44,5 \\
(14,5)\end{array}$ & 11 & $\begin{array}{r}40,7 \\
(12,9)\end{array}$ & 4 & $\begin{array}{r}14,8 \\
(13,8)\end{array}$ \\
\hline $15^{\circ} \mathrm{P} \leq \mathrm{IMC}<85^{\circ} \mathrm{P}$ & 120 & 60,9 & 48 & $\begin{array}{r}40,0 \\
(57,8)\end{array}$ & 53 & $\begin{array}{r}44,2 \\
(62,4)\end{array}$ & 19 & $\begin{array}{r}15,8 \\
(65,5)\end{array}$ \\
\hline $\mathrm{IMC} \geq 85^{\circ} \mathrm{P}$ & 50 & 25,4 & 23 & $\begin{array}{r}46,0 \\
(27,7)\end{array}$ & 21 & $\begin{array}{r}42,0 \\
(24,7)\end{array}$ & 6 & $\begin{array}{r}12,0 \\
(20,7)\end{array}$ \\
\hline TOTAL & 197 & 100,0 & 83 & {$[42,1]$} & 85 & {$[43,2]$} & 29 & {$[14,7]$} \\
\hline
\end{tabular}

$\chi^{2}=0,77$, com 4 graus de liberdade, não-significativo.

$\chi^{2}(\mathrm{MH})=0,20$, com 1 grau de liberdade, não-significativo.

Nota : As análises foram elaboradas, tendo por base as respostas válidas obtidas para 197 escolares.

- os números entre colchetes são os percentuais relativos ao total observado na linha

- os números entre parênteses são os percentuais em relação ao total observado na coluna.

Verifica-se que, entre os escolares com indicativo de baixo peso, $\left(\mathrm{IMC}<15^{\circ} \mathrm{P}\right)$, as proporções de mães que trabalham $(44,5 \%)$ ou não $(40,7 \%)$, fora do domicílio, podem ser consideradas muito próximas. Semelhante situação é observada quando se analisa o grupo de escolares com IMC $\geq 85^{\circ} \mathrm{P}$ (sobrepeso) e a atividade profissional da mãe: $46 \%$ trabalham fora do domicílio, enquanto $42 \%$ não o fazem. 
Infere-se, tendo também por base os resultados dos testes de quiquadrado, que não há associação estatisticamente significativa entre o estado nutricional dos escolares e as atividades profissionais da mãe fora do domicílio.

A Tabela 10, apresentada abaixo reúne resultados que, em parte, refletem a condição socioeconômica da família, pois há o envolvimento das variáveis "atividade profissional da mãe fora do domicílio" e os "estratos de renda familiar per capita".

Tabela 10. Distribuição dos escolares de acordo com a atividade profissional da mãe e estratos de renda familiar per capita. Piracicaba, 2001.

\begin{tabular}{|c|c|c|c|c|c|c|c|c|}
\hline \multirow{3}{*}{$\begin{array}{c}\text { Atividade } \\
\text { profissional da mãe } \\
\text { (fora do domicílio) }\end{array}$} & \multirow{2}{*}{\multicolumn{2}{|c|}{ Escolares }} & \multicolumn{6}{|c|}{ Estratos de renda familiar per capita (em reais) } \\
\hline & & & \multicolumn{2}{|c|}{$\leq 200,00$} & \multicolumn{2}{|c|}{$200,00-400,00$} & \multicolumn{2}{|c|}{$>400,00$} \\
\hline & $\mathrm{n}^{0}$ & $\%$ & $\mathrm{n}^{\circ}$ & $\%$ & no & $\%$ & no & $\%$ \\
\hline SIM & 73 & 42,7 & 45 & $\begin{array}{r}61,6 \\
(41,7)\end{array}$ & 23 & $\begin{array}{r}31,5 \\
(44,2)\end{array}$ & 5 & $\begin{array}{r}6,9 \\
(45,4)\end{array}$ \\
\hline NÃO & 69 & 40,4 & 44 & $\begin{array}{r}63,8 \\
(40,7)\end{array}$ & 22 & $\begin{array}{r}31,9 \\
(42,3)\end{array}$ & 3 & $\begin{array}{r}4,3 \\
(27,3)\end{array}$ \\
\hline $\begin{array}{l}\text { Desemprego } \\
\text { (recente) }\end{array}$ & 29 & 16,9 & 19 & $\begin{array}{r}65,5 \\
(17,6)\end{array}$ & 7 & $\begin{array}{r}24,2 \\
(13,5)\end{array}$ & 3 & $\begin{array}{r}10,3 \\
(27,3)\end{array}$ \\
\hline TOTAL & 171 & 100,0 & 108 & {$[63,2]$} & 52 & {$[30,4]$} & 11 & {$[6,4]$} \\
\hline
\end{tabular}

$\chi^{2}=1,69$, com 4 graus de liberdade, não-significativo.

$\chi^{2}(\mathrm{MH})=0,03$, com 1 grau de liberdade, não-significativo.

Nota : As análises foram elaboradas, tendo por base as respostas válidas obtidas para 171 escolares.

- os números entre colchetes são os percentuais relativos ao total observado na linha.

- os números entre parênteses são os percentuais em relação ao total observado na coluna.

É possível notar que $42,7 \%(n=73)$ das mães para as quais se dispõe de informações válidas, informaram que trabalham fora do domicílio. Entre estas, a maioria $(61,6 \%)$ pertencem ao estrato de menor renda familiar e apenas $6,9 \%$, pertencem a famílias com renda que supera $R \$ 400,00$.

No entanto, ao examinar os dados do grupamento de mães que não trabalham, a maior proporção $(63,8 \%)$ é encontrada no estrato de menor renda familiar. No estrato de maior renda familiar per capita será observado $4,3 \%$ de mães que não trabalham fora do domicílio. 
Merece atenção a proporção $(16,9 \%)$ de mães que se declararam desempregadas. Conforme o esperado, o grupo (65,5\%) se concentra no estrato de menor renda familiar per capita.

De acordo com os resultados dos testes estatísticos, não há associação entre as variáveis consideradas na análise.

\subsection{Consumo alimentar}

\subsubsection{Análise quantitativa}

Foram realizadas análises quantitativas, tendo como base 0 consumo alimentar dos escolares que compõem a amostra, no tocante æ̀ informações referentes à energia, macronutrientes (carboidratos, proteínas e lipídios), colesterol, fibras, vitamina $\mathrm{A}$, vitaminas hidrossolúveis (tiamina, riboflavina, niacina, folacina, vitamina $\mathrm{C}$ e ácido pantotênico) e minerais (cálcio, magnésio, zinco, fósforo, ferro, cobre e selênio).

De acordo com a descrição anterior, por meio do registro de alimentos (Recordatório 24 horas), e com a utilização do software Virtual Nutri (Philippi et al., 1996), foi possível obter uma série de dados que viabilizou a realização das análises que serão apresentadas nesta seção da dissertação.

Nas Tabelas 11 e 12, são mostrados os resultados referentes ao conteúdo médio diário de energia e nutrientes da dieta (discriminando-os de acordo com os percentis) e também, segundo o gênero dos escolares. 
Tabela 11. Distribuição dos percentis do consumo de energia e nutrientes dos escolares. Piracicaba, 2001.

\begin{tabular}{|c|c|c|c|c|c|}
\hline \multirow[t]{2}{*}{ Energia e nutrientes } & \multicolumn{5}{|c|}{ Percentis } \\
\hline & $10 \div P$ & $25 \div P$ & $50 \div P$ & $75^{\circ}$ & $90 \div P$ \\
\hline Energia (kcal) & 1137,52 & 1544,71 & 1993,84 & 2514,65 & 3103,83 \\
\hline Proteínas (g) & 37,37 & 53,19 & 74,22 & 94,18 & 115,71 \\
\hline Carboidratos (g) & 135,92 & 184,33 & 242,85 & 319,55 & 397,84 \\
\hline Lipídios totais (g) & 38,71 & 54,37 & 75,22 & 99,84 & 130,85 \\
\hline Colesterol (mg) & 53,28 & 111,47 & 183,63 & 278,64 & 420,90 \\
\hline Fibras (g) & 4,55 & 8,28 & 12,12 & 16,40 & 23,29 \\
\hline Vit. A ( $\mu \mathrm{g} R E)$ & 112,08 & 268,75 & 592,48 & 1179,16 & 2077,95 \\
\hline Tiamina (mg) & 1,25 & 1,75 & 2,45 & 3,11 & 4,17 \\
\hline Riboflavina (mg) & 0,86 & 1,24 & 1,71 & 2,36 & 3,37 \\
\hline Vit. B6 (mg) & 0,83 & 1,24 & 1,84 & 2,42 & 3,58 \\
\hline Niacina (mg) & 11,43 & 16,95 & 22,14 & 28,03 & 36,93 \\
\hline Folacina $(\mu \mathrm{g})$ & 58,94 & 89,16 & 140,41 & 214,18 & 312,35 \\
\hline Vit. C (mg) & 10,24 & 24,64 & 55,26 & 115,14 & 221,55 \\
\hline Ác. Pantot. (mg) & 1,39 & 2,04 & 2,93 & 4,13 & 5,39 \\
\hline Cálcio (mg) & 241,80 & 339,25 & 496,98 & 693,84 & 902,15 \\
\hline Magnésio (mg) & 93,90 & 132,75 & 180,23 & 237,78 & 318,83 \\
\hline Zinco (mg) & 3,21 & 5,64 & 9,02 & 14,50 & 17,82 \\
\hline Fósforo (mg) & 363,57 & 586,16 & 823,65 & 1112,54 & 1301,40 \\
\hline Ferro (mg) & 6,07 & 8,71 & 12,33 & 16,43 & 20,81 \\
\hline Cobre (mg) & 0,41 & 0,71 & 1,22 & 1,73 & 2,38 \\
\hline Selênio $(\mu \mathrm{g})$ & 31,54 & 48,37 & 68,81 & 93,73 & 118,12 \\
\hline
\end{tabular}

Nota: vit. é a abreviação adotada para identificar as Vitaminas, e Ác. Pantot. é utilizado para identificar o ácido pantotênico.

Os resultados contidos na Tabela 11 foram obtidos por meio de registro de consumo dos alimentos (Recordatório 24 horas), envolvendo um período de 24 horas. Assim, o conteúdo total de energia e nutrientes refere-se ao consumo de um dia. Registra-se que, em decorrência das limitações de tempo de permanência na escola, o consumo alimentar não foi obtido durante os mesmos dias agendados para a realização das análises sensoriais.

Analisando-se os resultados da Tabela 11 verifica-se que o valor $(1137,52 \mathrm{kcal})$ que separa os $10 \%$ dos alunos entrevistados com menor consumo de energia atinge apenas a metade do valor registrado na publicação Recomended Dietary Allowance - RDAs (NRC, 1989).

Examinando os dados da Tabela 11 verifica-se que $50 \%$ dos escolares revelaram consumo abaixo de 1993,84 kcal. Vale frisar que o referido 
conteúdo calórico é inferior ao valor de $2200 \mathrm{kcal}$ recomendado para o grupo (NRC, 1989).

Inversamente, ao analisar o valor máximo (3103,83 kcal) que separa os $10 \%$ da amostra que apresentou maior consumo energético, nota-se que é bem superior ao recomendado (valores entre 2200 a $2500 \mathrm{kcal}$ ) (NRC, 1989).

Caroba (2002) realizou pesquisa envolvendo adolescentes com idade entre 10 a 16 anos, matriculados na rede pública de ensino do município de Piracicaba e verificou que $50 \%$ da amostra, ingeriu conteúdo inferior a $1710,5 \mathrm{kcal}$, enquanto $10 \%$ dos escolares consumiram no mínimo $2916,0 \mathrm{kcal}$.

A ingestão calórica insuficiente, se persistente por um período prolongado, pode acarretar déficit de crescimento ou comprometimento da atividade física, com conseqüente diminuição da capacidade de aprendizagem. Por outro lado, a ingestão excessiva de energia resulta em aumento de peso e em distúrbios metabólicos que podem afetar a saúde, a médio prazo, como é o caso do aumento da prevalência de hipertensão arterial, diabetes, arteriosclerose e problemas cardíacos (Vannucchi et al., 1990).

Quando se analisa a ingestão de proteínas, verifica-se uma situação bastante similar à encontrada quando se analisou o consumo energético. Note-se que metade dos escolares, consumiu no máximo cerca de $74 \mathrm{~g}$, valor que é inferior ao preconizado pelas Dietary Reference Intakes - DRls estabelecidas pelo Institute of Medicine da National Academy of Sciences (2002).

A pesquisa realizada por Caroba (2002) revelou que o valor que distingue o grupamento (10\%) de escolares com menor consumo, foi de $36,4 \mathrm{~g}$ de proteínas, claramente inferior ao preconizado.

Quando se analisa os resultados referentes aos $10 \%$ dos escolares que revelaram maior consumo de proteína, encontra-se um valor substancialmente superior $(115,71 \mathrm{~g}$ ) ao recomendado (80 a $90 \mathrm{~g}$ ) (National Academy of Sciences, 2002). 
Pesquisas realizadas nos últimos anos, envolvendo adolescentes, revelaram um elevado consumo de alimentos ricos em proteínas (Albano, 2000; Kazapi et al., 2001 e Oliveira et al., 1998).

De acordo com Silva (2000) não é viável metabolicamente, nem economicamente atender as recomendações de energia por meio de alimentos ricos em proteínas.

Quando se analisa os dados obtidos para o grupo dos carboidratos, nota-se que apenas para o grupamento de escolares com maior consumo (75ㅇ P), o valor de $319,55 \mathrm{~g}$ insere-se no intervalo recomendado (302,50 g a 343,75 g) (National Academy of Sciences, 2002).

Para os $10 \%$ de menor consumo, o valor encontrado $(135,92 \mathrm{~g})$ é muito inferior ao preconizado (National Academy of Sciences, 2002).

É importante ressaltar que a presença de carboidratos na dieta é necessária para, assegurar, entre outras funções, as atividades do metabolismo normal de gorduras (Mahan \& Arlin, 1995).

No caso do consumo de lipídios, para o grupo de alunos (90ำ $\mathrm{P})$ com maior consumo, o menor valor encontrado foi $130,85 \mathrm{~g}$, o que é cerca de duas vezes mais ao valor preconizado $(70 \mathrm{~g}$ a $80 \mathrm{~g}$ ) (National Academy of Sciences, 2002).

Pesquisa implementada por Caroba (2002) identificou que o grupo de escolares com maior consumo, apresentou ingestão de no mínimo 121,40 g de lipídios, valor considerado elevado e no entanto, inferior ao encontrado na presente pesquisa $(130,85 \mathrm{~g})$.

Note-se que, segundo a literatura especializada, a elevada ingestão de lipídios favorece o surgimento de doenças crônicas na idade adulta.

Quanto à ingestão de colesterol constata-se um elevado consumo $(420,90 \mathrm{mg})$ entre o grupo de maior consumo $\left(90^{\circ} \mathrm{P}\right)$, valor bem superior ao recomendado (220 mg a $250 \mathrm{mg}$ ) pela Sociedade Brasileira de Alimentação e Nutrição - SBAN (Vannucchi et al, 1990). 
Os resultados obtidos na presente pesquisa merecem muita atenção, pois há evidências de risco de desenvolvimento de doenças crônicas, especialmente na idade adulta, para os indivíduos que consomem elevadas quantidades de colesterol.

Causa preocupação também, um resultado obtido que revelou que $90 \%$ da amostra, consumiu no máximo $23,29 \mathrm{~g}$ de fibras, ou seja, substancial maioria dos escolares ingerem quantidade menor à preconizada $(20 \mathrm{~g})$ pela SBAN (Vannucchi et al., 1990).

Vale registrar que a contribuição dos vegetais como fonte de fibra alimentar para a dieta, e seu impacto sobre a ocorrência de câncer de cólon, foram demonstrados por Lopes et al. (1986).

Tendo em vista o valor preconizado para o grupamento de idade e os resultados encontrados, é recomendável que a dieta receba reforço de alimentos ricos em fibras, como é o caso das frutas, hortaliças e grãos. Neste sentido, seria interessante que aliada à orientação nutricional, os alunos pudessem se beneficiar de refeições gratuitas, no âmbito da escola, com adequado conteúdo nutricional, especialmente, no tocante, por exemplo, às fibras e micronutrientes.

No entanto, deve-se atentar para que a ingestão diária de 20 a $30 \mathrm{~g}$ (ou no máximo tolerável de $35 \mathrm{~g}$ ) não seja ultrapassada, pois o elevado teor poderia interferir negativamente nos processos de absorção de zinco e cálcio, especialmente em crianças. Inversamente, conforme descrito anteriormente, o consumo insuficiente de fibras aumenta o risco de desenvolver câncer de cólon e doenças coronarianas (Mahan \& Arlin, 1995).

Quando se considera a ingestão de vitamina A, nota-se que $50 \%$ dos entrevistados apresentaram consumo abaixo de 592,48 ( $\mu \mathrm{g} R E$ ), valor considerado inferior ao preconizado (800 a $1000 \mu \mathrm{g} R$ ) (NRC, 1989).

Segundo Vannucchi et al. (1990), a vitamina A da dieta provém do retinol e de vários carotenóides, que são precursores da vitamina $A$. O retinol só é encontrado em alimentos de origem animal. Geralmente, são boas fontes de 
carotenos, algumas verduras de coloração verde-escuro (espinafre, mostarda, agrião e outras), e também aquelas que revelam cores intensas de amarelo, como é o caso da cenoura e da abóbora.

De acordo com Angelis (1999) os vegetais suprem, as necessidades dos indivíduos, desde que consumidos em quantidades adequadas, especialmente de $\beta$-caroteno, conhecido como pró-vitamina $A$. Dessa maneira, torna-se válido incentivar, sob orientação de especialistas, o aumento participação dos vegetais na dieta dos escolares.

No tocante aos resultados obtidos para as vitaminas hidrossolúveis (tiamina, riboflavina, vitamina $\mathrm{B} 6$ e niacina), verifica-se que as quantidades consumidas pela totalidade dos escolares, encontram-se em conformidade com os parâmetros estabelecidos pelas DRls (National Academy of Sciences, 2000).

Quando se analisa os dados de consumo de vitamina C, nota-se que $10 \%$ dos escolares ingeriram no máximo 10,24 mg. Esse valor é muito inferior àrecomendação de 45 mg (National Academy of Sciences, 2000).

Vale salientar que tendo por base a referência de $45 \mathrm{mg}$, cerca de $25 \%$ dos alunos da amostra revelam ingestão de vitamina C (24,64 mg) abaixo da considerada ideal para a adequada manutenção da saúde.

Outro aspecto que deve ser considerado é a ocorrência de perdas de vitamina $C$ durante a cocção dos alimentos. No caso das refeições servidas no âmbito das unidades de ensino, esse fato pode ocorrer, considerando-se que a maioria das hortaliças servidas aos escolares, são submetidas a processos de cocção durante período prolongado.

Esse é um resultado alarmante, pois a vitamina $C$ é essencial para aumentar a absorção do ferro não-heme e exerce, também, papel fundamental no metabolismo do ácido fólico. Acredita-se que expressivas concentrações de vitamina $\mathrm{C}$, auxiliam o organismo na resistência a infecções, previnem o câncer, diminuem o risco de desenvolver doenças cardiovasculares, auxiliam no tratamento da hipertensão e de cataratas (Bricarello \& Goulart, 1999). 
Torna-se válido, mediante a adoção de diversas estratégias, incentivar as crianças e adolescentes para que intensifiquem o consumo de frutas cítricas, tendo em vista que as mesmas constituem-se nas melhores fontes de vitamina C (Angelis, 1999).

Ainda de acordo com a Tabela 11, é possível verificar que o consumo de folacina pode ser considerado baixo, pois $75 \%$ dos alunos, consumiram no máximo $214,18 \mu \mathrm{g}$, enquanto o valor recomendado é de $300 \mu \mathrm{g}$.

De acordo com Mahan \& Arlin (1995) a deficiência de folacina é a mais comum hipovitaminose encontrada entre os humanos, podendo acarretar diminuição do crescimento, alterações sangüíneas, como por exemplo, a anemia e distúrbios no trato gastrointestinal.

Vale destacar que a deficiência prolongada de folacina produz a anemia macrocítica ou megaloblástica e, entre crianças, atraso do crescimento e da maturação cerebral (Ribeiro et al., 2002).

O consumo de vegetais reduz os riscos das crianças e adolescentes apresentarem deficiência de folacina. Esta vitamina é encontrada nos vegetais folhosos como o espinafre, o aspargo, o repolho e o brócolis e, em leguminosas, como o feijão (Ribeiro et al., 2002).

Ao examinar os dados sobre a ingestão de cálcio nota-se que ampla maioria (90\%), consome quantidade inferior $(902,15 \mathrm{mg})$ à recomendada (1300 mg/dia), pela National Academy of Sciences (2000).

Quando se analisa o consumo de magnésio, verifica-se que é reduzido, pois $50 \%$ da população avaliada consumiu no máximo 180,23 mg. Note-se que de acordo com as recomendações, o valor diário preconizado é $240 \mathrm{mg}$ (National Academy of Sciences, 2000).

Entre as conseqüências da deficiência prolongada de ingestão de magnésio, merece destaque a anorexia, a parada do crescimento, fraqueza muscular, irritabilidade e descontrole mental (Mahan \& Arlin, 1995).

Registra-se que o ferro é considerado um dos minerais que, nos últimos anos, mais tem atraído o interesse dos pesquisadores. $O$ referido 
mineral pode ser encontrado em todas as células dos seres vivos e está distribuído em todos os alimentos (Mahan \& Escott-Stump, 1998).

No entanto, nesta pesquisa merece destaque 0 resultado verificado (Tabela 8 ), que mostra o elevado percentual, cerca de $50 \%$ do grupo de escolares, com consumo diário inferior a $13 \mathrm{mg}$ do referido mineral, enquanto é preconizada a ingestão situada no intervalo de $12 \mathrm{mg}$ a $15 \mathrm{mg}$ (NRC, 1989).

Ao examinar os dados da Tabela 11 verifica-se que $50 \%$ do grupo de alunos, consumiu quantidade inferior a $10 \mathrm{mg}$ de zinco. Note-se que de acordo com o preconizado (NRC, 1989) a quantidade diária deveria integrar o intervalo de $12 \mathrm{mg}$ a $15 \mathrm{mg}$

A baixa ingestão de zinco pode acarretar perda de apetite, retardo no crescimento, dermatites, atraso na cicatrização de lesões, diminuição do paladar, atraso na maturação sexual e cegueira noturna (Mahan \& Arlin, 1995 e Vannucchi et al., 1990).

Tendo em vista 0 crescente interesse pelas diferenças comportamentais, revelada por meninos e meninas, especialmente no tocante à escolha e consumo de alimentos, apresenta-se a seguir os resultados relativos aos percentis do consumo de energia e nutrientes selecionados, distinguindo-se os escolares por gênero (Tabela 12). 
Tabela 12. Distribuição dos percentis do consumo de energia e nutrientes, de acordo com o gênero dos escolares. Piracicaba, 2001.

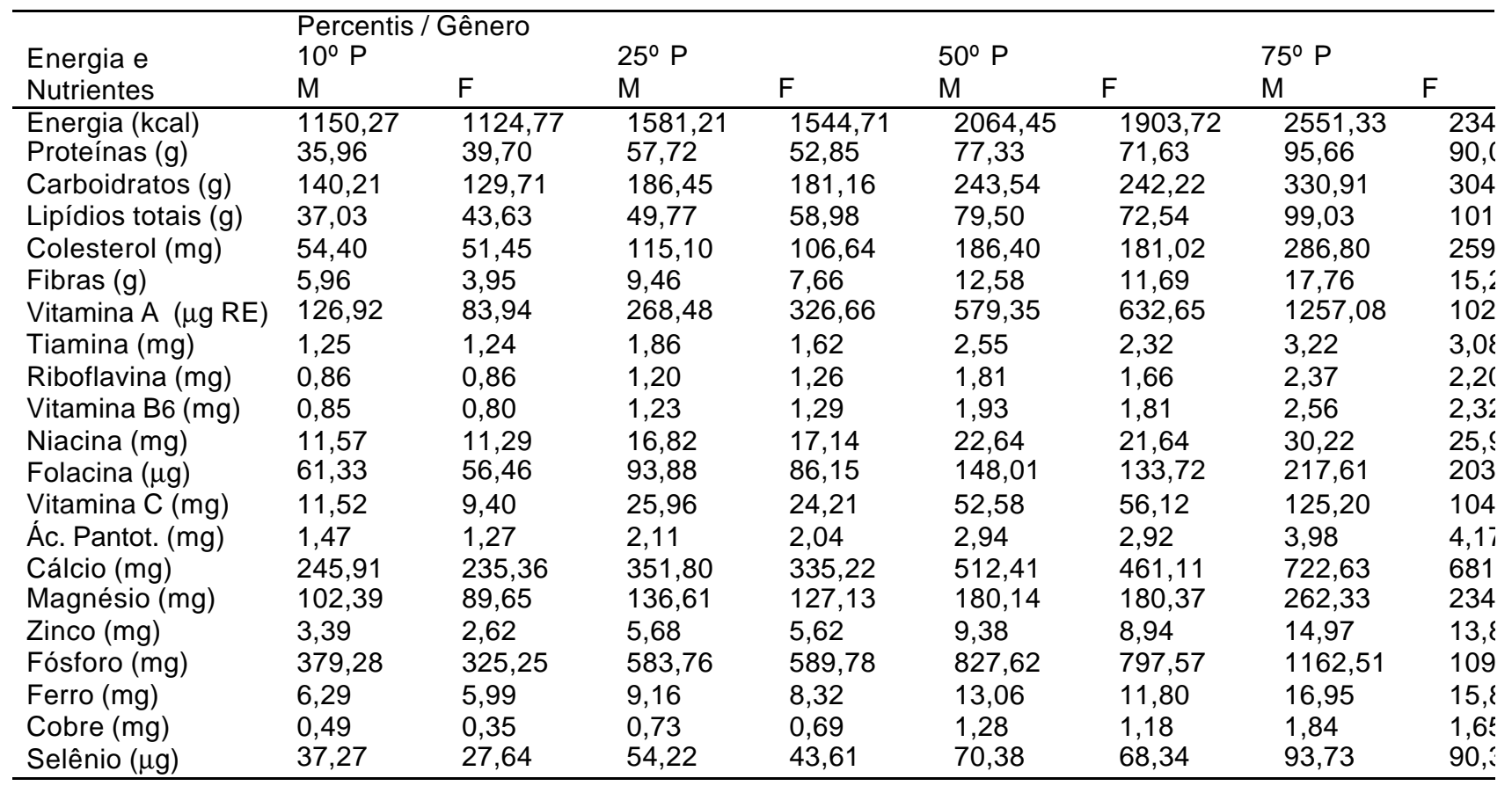

Nota: Ác.Pantot. é a abreviação adotada para identificar o Ácido Pantotênico. 
Ao examinar o consumo energético observa-se que, de forma sistemática, as meninas ingeriram menor conteúdo de calorias. Vale destacar que $50 \%$ das alunas adotaram dietas cujo conteúdo energético não ultrapassou 1903,72 kcal, inferior, portanto a $2200 \mathrm{kcal}$ recomendado pelo NRC (1989).

Caroba (2002), analisando o consumo alimentar de escolares, com idade entre 10 e 16 anos e, adotando a técnica estatística de regressão múltipla, verificou que a cada mês adicional na idade dos meninos, elevava-se o consumo em 4,73 kcal. No entanto, para as meninas esse consumo diminuía 2,14 kcal por mês.

Ainda de acordo com o referido autor "o coeficiente referente à diferença de comportamento, no tocante ao consumo energético, entre os gêneros é estatisticamente diferente de zero ao nível de significância de 5\%" (Caroba, 2002, p.99).

Caroba (2002) ao analisar o consumo de energia, verificou que a cada mês acrescido àidade dos escolares, ao consumo é adicionado 0,26 $\mathrm{g}$ de proteína, enquanto para as meninas esse consumo decresce em 0,05 g.

Pesquisa de Albano (2000), envolvendo 125 alunos com idade entre 11 e 17 anos, também mostrou que os meninos tinham consumo de energia muito superior quando comparado ao conteúdo observado para as meninas.

Sichieri (1998) desenvolveu uma pesquisa com adolescentes integrantes da faixa de idade de 12 a 14 anos, encontrando resultados que revelaram médias de consumo energético de $2885 \mathrm{kcal}$ e de $2848 \mathrm{kcal}$ para o gênero masculino e feminino, respectivamente. Note-se que, nesse caso, praticamente não há diferença, entre meninos e meninas, no que tange o consumo energético.

Um trabalho divulgado pelo Instituto Sodexho para o Desenvolvimento da Qualidade de Vida no Cotidiano (2001), mostrou que em países como o Brasil, os Estados Unidos, a Bélgica, o Canadá, a França, a Alemanha, a Holanda, a Espanha, a Itália, a Suécia e o Reino Unido, o 
consumo diário de energia por crianças e adolescentes (da faixa etária de $5 \mathrm{a}$ 17 anos) tem revelado queda sistemática nos últimos 40 anos. Esta tendência fica mais clara, quando se observa a diferença crescente do consumo de energia entre meninos e meninas.

Ainda de acordo com a referida pesquisa, em 2000, os meninos consumiram diariamente uma média de $55,8 \%$ de energia a mais do que as meninas. A publicação destaca as diferenças, obtidas junto à população de diversos países, quando se considera o consumo de energia, revelada, distinguindo-se os jovens, de acordo com o gênero (Instituto Sodexho para o Desenvolvimento da Qualidade de Vida no Cotidiano, 2001).

Analisando os dados publicados em 2000 pelo Instituto Sodexho para o Desenvolvimento da Qualidade de Vida no Cotidiano (2000), em locais com tradição de valorizar os processos envolvidos no ritual de preparo de refeições, isto é, onde a alimentação recebe maior cuidado e dedicação, as meninas tendem a limitar o consumo ainda mais drasticamente. Assim, a diferença na ingestão calórica entre meninos e meninas é maior na França (69\%) e menor no Canadá (21\%).

É interessante frisar que os meninos despendem energia para se impor, entre os integrantes do seu grupo, enquanto as meninas limitam o consumo de energia para serem aceitas pelos grupos. Ainda de acordo com a pesquisa, no Brasil, os meninos consomem, em média, $2850 \mathrm{kcal}$ por dia, enquanto que as meninas ingerem $2170 \mathrm{kcal}$ diariamente (Instituto Sodexho para o Desenvolvimento da Qualidade de Vida no Cotidiano, 2001). Vale registrar que a referida pesquisa não analisou os dados de consumo alimentar, levando em consideração os diferentes estratos de renda da população.

Ao analisar os dados referentes à proteína obtidos pela presente pesquisa, observa-se que somente entre o grupamento de escolares com menor consumo, as meninas revelaram maior ingestão de proteína $(39,70 \mathrm{~g})$, enquanto que, para os meninos o valor aproximado foi de $36 \mathrm{~g}$. 
Quando se considera o consumo de lipídios verifica-se que para $50 \%$ da população analisada $\left(50^{\circ} \mathrm{P}\right)$, os valores não atingiram o preconizado. Note-se que, na presente pesquisa foi observado 131,33 g e 127,77 g de consumo de lipídios totais, para escolares do gênero masculino e feminino, respectivamente, quando se considerou os dados obtidos para o grupo de maior consumo $\left(90^{\circ} \mathrm{P}\right)$. Enquanto que a recomendação média para os escolares, integrantes da amostra, de acordo com a National Academy of Sciences (2002) é 83,33 g para meninos e, 73,33 g para meninas.

No tocante à ingestão de colesterol, nota-se que para os escolares do gênero masculino, o consumo foi, de forma geral, superior ao observado entre as alunas. Somente entre os $10 \%$ dos alunos com maior consumo, a ingestão de colesterol pelas meninas superou a verificada para os meninos. Observou-se para o grupo de maior consumo $\left(90^{\circ} \mathrm{P}\right)$, que a ingestão de colesterol, para os escolares de ambos os gêneros, foi superior æ̀̀ recomendações da SBAN (250 mg e 220 mg para meninos e meninas, respectivamente) (Vannucchi et al., 1990).

Kazapi et al. (2000), implementando um estudo envolvendo adolescentes matriculados nas redes (pública e privada) de ensino da cidade de Florianópolis, Santa Catarina e, adotando como parâmetro os valores de energia propostos pela SBAN (Vannucchi et al., 1990), verificaram que mais de $50 \%$ dos adolescentes apresentaram baixo consumo energético; adequada ingestão de carboidratos; alto consumo de proteínas e elevada ingestão de lipídios. Tendo por base exclusivamente a amostra de escolares da rede pública, os autores observaram proporção de adolescentes do gênero masculino, com elevado consumo de carboidratos, baixa ingestão de lipídios, elevado consumo de energia e proteínas.

Em relação à ingestão de fibras, na presente pesquisa, verificouse que os escolares do gênero masculino, de forma sistemática, consomem maior quantidade de fibras, quando comparada à ingestão registrada para as meninas. No entanto, vale frisar que, somente aqueles pertencentes ao grupo 
dos $10 \%$ com consumo mais elevado, alcançaram o valor preconizado pela SBAN (Vannucchi et al., 1990).

Ainda de acordo com a Tabela 12, vale destacar que $90 \%$ dos alunos, consumiram quantidade de fibra inferior a $24,57 \mathrm{~g}$ enquanto para as alunas, o consumo não ultrapassou 19,95 g, sendo que esse valor se revela próximo ao mínimo de $20 \mathrm{~g}$ recomendado pela SBAN (Vannucchi et al., 1990).

De acordo com Angelis (1999) o consumo adequado de fibras promove o aumento do volume fecal, acelerando assim a velocidade do trânsito intestinal, induzido principalmente pela fração insolúvel das fibras, como é o caso da celulose. As fibras, por meio da promoção da fermentação ocorrida no intestino, induzem a produção de metabólitos que inibem a síntese de colesterol no fígado. Dessa forma, as fibras adquirem especial importância na prevenção de diverticulites, hemorróidas, constipação intestinal, diabetes e doenças cardiovasculares.

Vale lembrar que as fibras são encontradas em alimentos como farelo de aveia, feijão, pêssego, maçã, mamão, cereais integrais e vegetais folhosos (Angelis, 1999 e Bricarello \& Goulart, 1999).

Ainda tendo por base a Tabela 12, observa-se no tocante ao consumo de vitamina $A$, para o grupo de escolares, de ambos os gêneros, com menor consumo, os valores se revelaram muito abaixo (126,92 $\mu \mathrm{g} R E$ e $83,94 \mu \mathrm{g}$ RE para meninos e meninas, respectivamente) do recomendado, que de acordo com o NRC (1989) deve ser $1000 \mu \mathrm{g}$ RE para meninos e 800 $\mu \mathrm{gRE}$ para meninas.

Quando se considera o grupo das vitaminas hidrossolúveis (tiamina, riboflavina, vitamina B6 e niacina) verifica-se que para os escolares de ambos os gêneros, o consumo pode ser considerado satisfatório. Vale notar que de acordo com os valores preconizados pela National Academy of Sciences (2000), os valores médios recomendados são: 0,9 mg (tiamina), 0,9 mg (riboflavina), $1 \mathrm{mg}$ (vitamina B6) e $12 \mathrm{mg}$ (niacina). 
No tocante à folacina, vale registrar que $90 \%$ dos alunos do gênero masculino integrantes da amostra consumiram valores inferiores a $320,37 \mu \mathrm{g}$, enquanto que para as alunas, o conteúdo da dieta não alcançou $280,23 \mu \mathrm{g}$. Contudo, cabe registrar que o valor médio recomendado pela National Academy of Sciences (2000) é de $300 \mu \mathrm{g} / \mathrm{dia}$.

Segundo Angelis (1999) os principais sinais de deficiência de ácido fólico são palidez, fraqueza, perda de memória, distração, insônia e ataques de euforia.

Ainda de acordo com a Tabela 12, no caso da vitamina C, somente $50 \%$ da amostra observada, revelou consumo superior a $45 \mathrm{mg}$, ou seja, valores (52,58 mg e 56,12 mg para alunos e alunas, respectivamente) reconhecidos como adequados (National Academy of Sciences, 2000).

A vitamina $C$, também conhecida como ácido ascórbico, além de suas funções que integram o metabolismo intermediário, favorece também a absorção do ferro. Tendo em vista que o ácido ascórbico é destruído com o calor excessivo, em presença de oxigênio, é provável a ocorrência de superestimação da quantidade de vitamina $C$ que é proveniente dos alimentos que foram submetidos ao cozimento, antes de serem consumidos (Vannucchi et al., 1990).

No cardápio da merenda da cidade de Piracicaba, a maioria dos alimentos oferecidos para os escolares, são na forma cozida. Assim é necessário admitir que parte do ácido ascórbico presente no alimento é destruída durante o preparo e também como conseqüência dos longos períodos que permanecem expostos à ação do oxigênio, durante os intervalos que antecedem a distribuição aos escolares.

As frutas constituem-se em boas fontes da referida vitamina, uma vez que são, freqüentemente, consumidas cruas e frescas. Uma grande variedade de frutas apresentam elevado teor de vitamina C, como é o caso da laranja, do caju, da goiaba, da acerola e do abacaxi. Algumas verduras e hortaliças, como por exemplo o brócolis, o espinafre e outras que possuem 
folhas verdes, também oferecem quantidades apreciáveis da referida vitamina (Vannucchi et al., 1990).

Um dado preocupante que se observa ao examinar a Tabela 12, é a baixa quantidade de cálcio ingerida pelos escolares. Verifica-se que o valor que discrimina os $10 \%$ dos alunos com a maior presença desse mineral na dieta, é $891,37 \mathrm{mg}$ e $943,37 \mathrm{mg}$, para meninos e meninas, respectivamente. Esses valores são muito inferiores ao valor recomendado $(1300 \mathrm{mg})$ pela National Academy of Sciences (2000).

O cálcio é um dos principais constituintes da estrutura óssea e 99\% do cálcio do corpo é encontrado nos ossos e dentes. Esse mineral desempenha papel importante na prevenção e controle da osteoporose, doença que acomete principalmente as mulheres, e por esse motivo recomenda-se uma ingestão adequada de cálcio desde a infância (Vannucchi et al., 1990).

A deficiência de cálcio também pode causar raquitismo (em crianças), tetania (espasmos musculares semelhantes a cãibras) e hipertensão (Mahan \& Arlin, 1995).

Segundo Probióticos...(2002), uma em cada duas mulheres, e um em cada oito homens, desenvolverão a osteoporose nos próximos anos. Esta é uma doença do esqueleto, na qual os ossos se tornam muito frágeis que até mesmo uma queda, aparentemente, sem gravidade, ou as atividades simples do cotidiano, podem causar fraturas espontâneas. A diminuição da massa óssea e a deterioração do tecido ósseo, são os fatores que causam o aumento da fragilidade dos ossos.

De acordo com Angelis (1999), aproximadamente 99\% do cálcio corporal estão contidos nos ossos. Todavia, este depósito na forma de fosfatos não é estático. Continuamente ocorrem trocas entre os ossos e o cálcio presente na circulação. Vale lembrar ainda que a vitamina $D$ desempenha papel importante, contribuindo para o depósito de cálcio na matriz óssea.

Trabalho de Albano (2000) mostrou que a média de consumo de cálcio para indivíduos do gênero masculino foi de $819,68 \mathrm{mg}$ e para o gênero 
feminino, 579,86 mg. De acordo com o autor, a National Osteoporosis Foundation registra que o consumo de cálcio inferior a $1200 \mathrm{mg} / \mathrm{dia}$ é considerado como um fator de risco para a osteoporose.

$\mathrm{Na}$ pesquisa implementada por Sichieri (1998), tendo como amostra indivíduos com idade entre 12 e 14 anos, foram verificadas médias de ingestão diária de cálcio de 1061 mg e 1150 mg para os jovens dos gêneros masculino e feminino, respectivamente.

Segundo Angelis (1999), as principais fontes nutricionais de cálcio são leite e seus derivados, sardinhas, camarão e alguns vegetais, como nabo, beterraba, salsa, espinafre e couve.

Um resultado bastante surpreendente encontrado nesta pesquisa relaciona-se com a baixa ingestão de ferro pelos escolares. Somente $50 \%$ da população de escolares do gênero masculino, consumiram no mínimo 13,06mg de ferro, valor que atende as recomendações do NRC (1989). A situação tornase ainda mais crítica quando se analisa o grupo de escolares com menor consumo do mineral, pois a ingestão $(6,29 \mathrm{mg}$ e $5,99 \mathrm{mg}$ para meninos e meninas, respectivamente), praticamente atinge a metade do valor recomendado (NRC, 1989).

Quando se observa a dieta das meninas, verifica-se que a situação é ainda pior. Note-se que revelam menor consumo de ferro, quando se compara os resultados com os valores obtidos para os meninos.

Cerca de $50 \%$ das meninas entrevistadas não consumiram um valor mínimo de ferro recomendado (15 mg) (NRC, 1989). Este dado é muito preocupante, pois na adolescência, com a menstruação, as adolescentes têm uma perda periódica de sangue e tal quantidade deve ser compensada com um aumento do referido mineral na dieta (Vannucchi et al., 1990).

Ressalta-se que a deficiência de ferro é a mais comum de todas as deficiências minerais, sendo que as meninas adolescentes são consideradas grupo de risco (Mahan \& Arlin, 1995). 
A anemia é caracterizada pela redução do número e tamanho das hemáceas, o que limita o transporte de $\mathrm{O}_{2}$ e $\mathrm{CO}_{2}$, entre o sangue e células dos tecidos. A anemia ferropriva é um problema de saúde pública altamente prevalente em todo o mundo, afetando, principalmente a capacidade de trabalho dos indivíduos (Angelis, 1999).

Segundo Silva (1996) a anemia está associada à redução no consumo de feijões e carnes, considerados fontes importantes de ferro e, além disso, a ausência de frutas e verduras na dieta, consideradas fontes de vitamina A e $\mathrm{C}$, que desempenham papel potencializador da biodisponibilidade de ferro. Porém é válido ressaltar que o feijão continua sendo um alimento habitualmente consumido no Brasil, reconhecido como importante fonte de proteína e de energia, sobretudo para as populações mais pobres. Essa leguminosa apresenta um teor relativamente elevado de ferro (cerca de $7 \mathrm{mg} / 100 \mathrm{~g}$ ), porém o mineral é pouco absorvido pelo organismo (em torno de 3 a $5 \%$ ) devido à presença no grão, de fitatos e taninos que inibem a absorção de ferro (Almeida \& Naves, 2002).

Pesquisa realizada por Albano (2000) revelou que a média do consumo do ferro foi $13,37 \mathrm{mg}$ e $12,13 \mathrm{mg}$, para os jovens do gênero masculino e feminino, respectivamente.

$\mathrm{Na}$ pesquisa desenvolvida por Sichieri (1998), o autor encontrou na dieta dos indivíduos avaliados, valores médios mais elevados, ou seja, $17,7 \mathrm{mg}$ para os meninos e $16,1 \mathrm{mg}$, para o grupo das meninas.

Pesquisa implementada por Samuelson et al. (1996) revelou consumo $18,2 \mathrm{mg}$ e 14,2 mg de ferro para os escolares do gênero masculino e feminino, respectivamente.

Por meio de análise de dados obtidos pelo método Recordatório de 24 horas, Tseng et al. (1997) verificaram que a média da quantidade de ferro consumida por indivíduos com idade entre 7 e 13 anos, foi de 11,5 mg para os meninos e 10,5 mg para as meninas. Vale destacar que os valores também 
foram considerados baixos, situação que, invariavelmente condiciona, a médio prazo, o comprometimento da saúde das crianças.

$\mathrm{Na}$ presente pesquisa julgou-se pertinente explorar, pormenorizadamente, a participação dos alimentos de origem vegetal no valor calórico total da dieta dos escolares da rede pública de ensino.

Os resultados foram registrados nas Tabelas (13 e 14), apresentadas a seguir. 
Tabela 13. Participação média de energia e nutrientes, provenientes do consumo de hortaliças, na dieta de escolares, de acordo com o gênero, matriculados na rede pública de ensino de Piracicaba, 2001.

\begin{tabular}{|c|c|c|c|c|c|c|}
\hline \multirow{3}{*}{$\begin{array}{c}\text { Energia } \\
e \\
\text { Nutrientes }\end{array}$} & \multirow{2}{*}{\multicolumn{3}{|c|}{ Masculino }} & \\
\hline & & & & Conteúdo & Feminino & \\
\hline & Total & Quantidade & $(\%)$ & Total & Quantidade & $(\%)$ \\
\hline Energia (Kcal) & $\begin{array}{r}2107,74 \\
(798,27)\end{array}$ & $\begin{array}{r}70,28 \\
(161,86)\end{array}$ & 3,33 & $\begin{array}{r}2054,03 \\
(800,13)\end{array}$ & $\begin{array}{r}71,15 \\
(141,93)\end{array}$ & 3,46 \\
\hline Proteínas (g) & $\begin{array}{r}77,65 \\
(32,97)\end{array}$ & $\begin{array}{r}2,69 \\
(5,86)\end{array}$ & 3,46 & $\begin{array}{r}75,55 \\
(34,77)\end{array}$ & $\begin{array}{r}3,15 \\
(6,77)\end{array}$ & 4,17 \\
\hline Carboidratos (g) & $\begin{array}{l}263,99 \\
(116,89)\end{array}$ & $\begin{array}{r}8,26 \\
(20,07)\end{array}$ & 3,13 & $\begin{array}{r}248,32 \\
(98,73)\end{array}$ & $\begin{array}{r}7,27 \\
(13,54)\end{array}$ & 2,93 \\
\hline Lipídios (g) & $\begin{array}{l}79,81 \\
(38,07)\end{array}$ & $\begin{array}{r}3,17 \\
(7,68)\end{array}$ & 3,97 & $\begin{array}{r}83,55 \\
(45,28)\end{array}$ & $\begin{array}{r}3,44 \\
(8,40)\end{array}$ & 4,12 \\
\hline Fibras (g) & $\begin{array}{r}13,78 \\
(7,06)\end{array}$ & $\begin{array}{r}1,30 \\
(2,14)\end{array}$ & 9,43 & $\begin{array}{r}12,18 \\
(7,03)\end{array}$ & $\begin{array}{r}1,06 \\
(1,61)\end{array}$ & 8,70 \\
\hline Colesterol (mg) & $\begin{array}{l}343,26 \\
(891,81)\end{array}$ & $\begin{array}{r}0 \\
(0)\end{array}$ & 0 & $\begin{array}{l}272,62 \\
(637,61)\end{array}$ & $\begin{array}{r}0 \\
(0)\end{array}$ & 0 \\
\hline Vitamina A ( $\mu \mathrm{g}$ RE) & $\begin{array}{l}1114,40 \\
(2161,32)\end{array}$ & $\begin{array}{l}248,07 \\
(523,11)\end{array}$ & 22,26 & $\begin{array}{r}990,87 \\
(1585,81)\end{array}$ & $\begin{array}{l}284,84 \\
(598,35)\end{array}$ & 28,75 \\
\hline Vitamina C (mg) & $\begin{array}{r}95,24 \\
(107,57)\end{array}$ & $\begin{array}{r}9,62 \\
(16,45)\end{array}$ & 10,10 & $\begin{array}{r}88,08 \\
(94,99)\end{array}$ & $\begin{array}{r}10,26 \\
(15,40)\end{array}$ & 11,65 \\
\hline Tiamina (mg) & $\begin{array}{r}2,72 \\
(1,47)\end{array}$ & $\begin{array}{r}0,07 \\
(0,15)\end{array}$ & 2,57 & $\begin{array}{r}2,51 \\
(1,46)\end{array}$ & $\begin{array}{r}0,07 \\
(0,09)\end{array}$ & 2,79 \\
\hline Riboflavina (mg) & $\begin{array}{r}2,06 \\
(1,36)\end{array}$ & $\begin{array}{r}0,05 \\
(0,10)\end{array}$ & 2,43 & $\begin{array}{r}1,91 \\
(1,10)\end{array}$ & $\begin{array}{r}0,06 \\
(0,09)\end{array}$ & 3,14 \\
\hline Vitamina B6 (mg) & $\begin{array}{r}2,08 \\
(1,19)\end{array}$ & $\begin{array}{r}0,09 \\
(0,16)\end{array}$ & 4,33 & $\begin{array}{r}1,92 \\
(1,04)\end{array}$ & $\begin{array}{r}0,10 \\
(0,15)\end{array}$ & 5,21 \\
\hline Vit.amina B12 $(\mu \mathrm{g})$ & $\begin{array}{r}6,98 \\
(20,82)\end{array}$ & $\begin{array}{r}0,16 \\
(0,50)\end{array}$ & 2,29 & $\begin{array}{r}5,33 \\
(14,71)\end{array}$ & $\begin{array}{r}0,23 \\
(0,72)\end{array}$ & 4,32 \\
\hline Niacina (mg) & $\begin{array}{l}24,18 \\
(11,37)\end{array}$ & $\begin{array}{r}0,88 \\
(1,78)\end{array}$ & 3,64 & $\begin{array}{l}22,77 \\
(11,17)\end{array}$ & $\begin{array}{r}0,78 \\
(1,37)\end{array}$ & 3,43 \\
\hline Folacina $(\mu \mathrm{g})$ & $\begin{array}{r}175,83 \\
(124,95)\end{array}$ & $\begin{array}{l}20,04 \\
(26,35)\end{array}$ & 11,40 & $\begin{array}{r}156,13 \\
(101,26)\end{array}$ & $\begin{array}{l}22,10 \\
(28,63)\end{array}$ & 14,15 \\
\hline Ác. Pantotênico (mg) & $\begin{array}{r}3,27 \\
(1,84)\end{array}$ & $\begin{array}{r}0,22 \\
(0,39)\end{array}$ & 6,73 & $\begin{array}{r}3,20 \\
(1,71)\end{array}$ & $\begin{array}{r}0,22 \\
(0,27)\end{array}$ & 6,88 \\
\hline Vitamina E (mg) & $\begin{array}{r}15,71 \\
(9,20)\end{array}$ & $\begin{array}{r}0,98 \\
(1,83)\end{array}$ & 6,24 & $\begin{array}{r}14,41 \\
(10,12)\end{array}$ & $\begin{array}{r}1,04 \\
(1,83)\end{array}$ & 7,22 \\
\hline Sódio (mg) & $\begin{array}{l}2728,00 \\
(1410,03)\end{array}$ & $\begin{array}{l}182,10 \\
(476,22)\end{array}$ & 6,67 & $\begin{array}{l}2688,32 \\
(1406,07)\end{array}$ & $\begin{array}{l}141,80 \\
(316,03)\end{array}$ & 5,27 \\
\hline Cálcio (mg) & $\begin{array}{l}552,07 \\
(261,27)\end{array}$ & $\begin{array}{l}20,95 \\
(46,60)\end{array}$ & 3,79 & $\begin{array}{l}538,72 \\
(293,95)\end{array}$ & $\begin{array}{r}17,91 \\
(22,52)\end{array}$ & 3,32 \\
\hline Magnésio (mg) & $\begin{array}{r}198,80 \\
(94,08)\end{array}$ & $\begin{array}{r}11,30 \\
(19,31)\end{array}$ & 5,68 & $\begin{array}{r}189,43 \\
(92,26)\end{array}$ & $\begin{array}{r}11,36 \\
(14,28)\end{array}$ & 6,00 \\
\hline Zinco (mg) & $\begin{array}{r}11,06 \\
(6,93)\end{array}$ & $\begin{array}{r}0,53 \\
(1,24)\end{array}$ & 4,79 & $\begin{array}{r}10,06 \\
(6,44)\end{array}$ & $\begin{array}{r}0,49 \\
(1,23)\end{array}$ & 4,87 \\
\hline Potássio (mg) & $\begin{array}{l}2167,34 \\
(1020,96)\end{array}$ & $\begin{array}{r}188,63 \\
(292,43)\end{array}$ & 8,70 & $\begin{array}{r}2081,77 \\
(986,07)\end{array}$ & $\begin{array}{l}196,41 \\
(234,40)\end{array}$ & 9,43 \\
\hline Fósforo (mg) & $\begin{array}{l}874,59 \\
(394,05)\end{array}$ & $\begin{array}{r}37,71 \\
(77,11)\end{array}$ & 4,31 & $\begin{array}{r}829,30 \\
(396,34)\end{array}$ & $\begin{array}{l}35,07 \\
(61,83)\end{array}$ & 4,23 \\
\hline Ferro (mg) & $\begin{array}{r}13,64 \\
(5,80)\end{array}$ & $\begin{array}{r}0,73 \\
(1,39)\end{array}$ & 5,35 & $\begin{array}{r}12,54 \\
(5,72)\end{array}$ & $\begin{array}{r}0,62 \\
(1,06)\end{array}$ & 4,94 \\
\hline Cobre (mg) & $\begin{array}{r}1,47 \\
(1,12)\end{array}$ & $\begin{array}{r}0,07 \\
(0,13)\end{array}$ & 4,76 & $\begin{array}{r}1,30 \\
(0,95)\end{array}$ & $\begin{array}{r}0,07 \\
(0,09)\end{array}$ & 5,38 \\
\hline Selênio $(\mu \mathrm{g})$ & $\begin{array}{r}75,89 \\
(32,77)\end{array}$ & $\begin{array}{r}2,74 \\
(6,75)\end{array}$ & 3,61 & $\begin{array}{l}70,83 \\
(35,65)\end{array}$ & $\begin{array}{r}2,43 \\
(5,52)\end{array}$ & 3,43 \\
\hline
\end{tabular}

Nota: os números entre parênteses são os desvios-padrão. 
Analisando os dados da Tabela 13, é possível verificar a nítida diferença existente, quando se verifica a participação (percentual) da energia e de diversos nutrientes, provenientes de hortaliças, na dieta de meninos e meninas.

Note-se que a participação do conjunto formado pelas vitaminas $A$ e $E$, vitamina $C$, tiamina, riboflavina, vitaminas $B 6$ e $B 12$, folacina, ácido pantotênico, proteína e lipídios (provenientes das hortaliças) é claramente maior na dieta das meninas.

No entanto, se forem retomadas as informações apresentadas anteriormente (Tabela 12), verifica-se que as meninas, de forma geral consumiram menor quantidade da maioria dos referidos nutrientes. Porém, quando se considera o consumo de hortaliças e sua contribuição nutricional para a dieta, não sobram dúvidas que as alunas, de forma geral, estavam se beneficiando de forma mais efetiva das vantagens do consumo de alimentos de origem vegetal.

Quando se observa a participação das fibras, a contribuição das hortaliças é maior $(9,43 \%)$ para os meninos, ao se comparar com o valor $(8,70 \%)$ identificado na dieta das alunas.

Examinando o grupamento formado pelos minerais cálcio, fósforo, ferro e selênio, verifica-se que a participação dos referidos nutrientes (provenientes das hortaliças) é mais elevada para os meninos.

Pesquisa envolvendo a análise qualitativa da dieta dos alunos da Rede Estadual de Ensino do Município de Piracicaba (SP) revelou que 48,6\% apresentavam adequação de consumo quanto ao grupamento das carnes e $45,8 \%$, com relação ao grupo dos lácteos. No entanto, os autores verificaram que somente $35,4 \%$ dos alunos apresentavam adequação da dieta quanto a participação dos cereais e $28,2 \%$ com relação às hortaliças. A dieta apresentouse inadequada para $63,3 \%$ dos alunos no tocante ao consumo de frutas (Silva et al., 1998). 
Vale registrar que na pesquisa realizada com 153 adolescentes de ambos os gêneros, foi possível verificar que houve um maior consumo de frutas e hortaliças entre os adolescentes do sexo feminino. Os autores ressaltaram, porém, que os meninos representam um grupo mais suscetível æ̀ doenças cardiovasculares que podem ser prevenidas, em parte, com 0 adequado consumo de frutas e hortaliças (Nobre \& Furtado, 1994).

$\mathrm{Na}$ Tabela 14, apresentada a seguir, foram sistematizados os dados relativos a participação da energia e nutrientes provenientes das frutas, na dieta dos escolares integrantes da pesquisa. 
Tabela 14. Participação média de energia e nutrientes, provenientes do consumo de frutas, na dieta de escolares, de acordo com o gênero, matriculados na rede pública de ensino de Piracicaba, 2001.

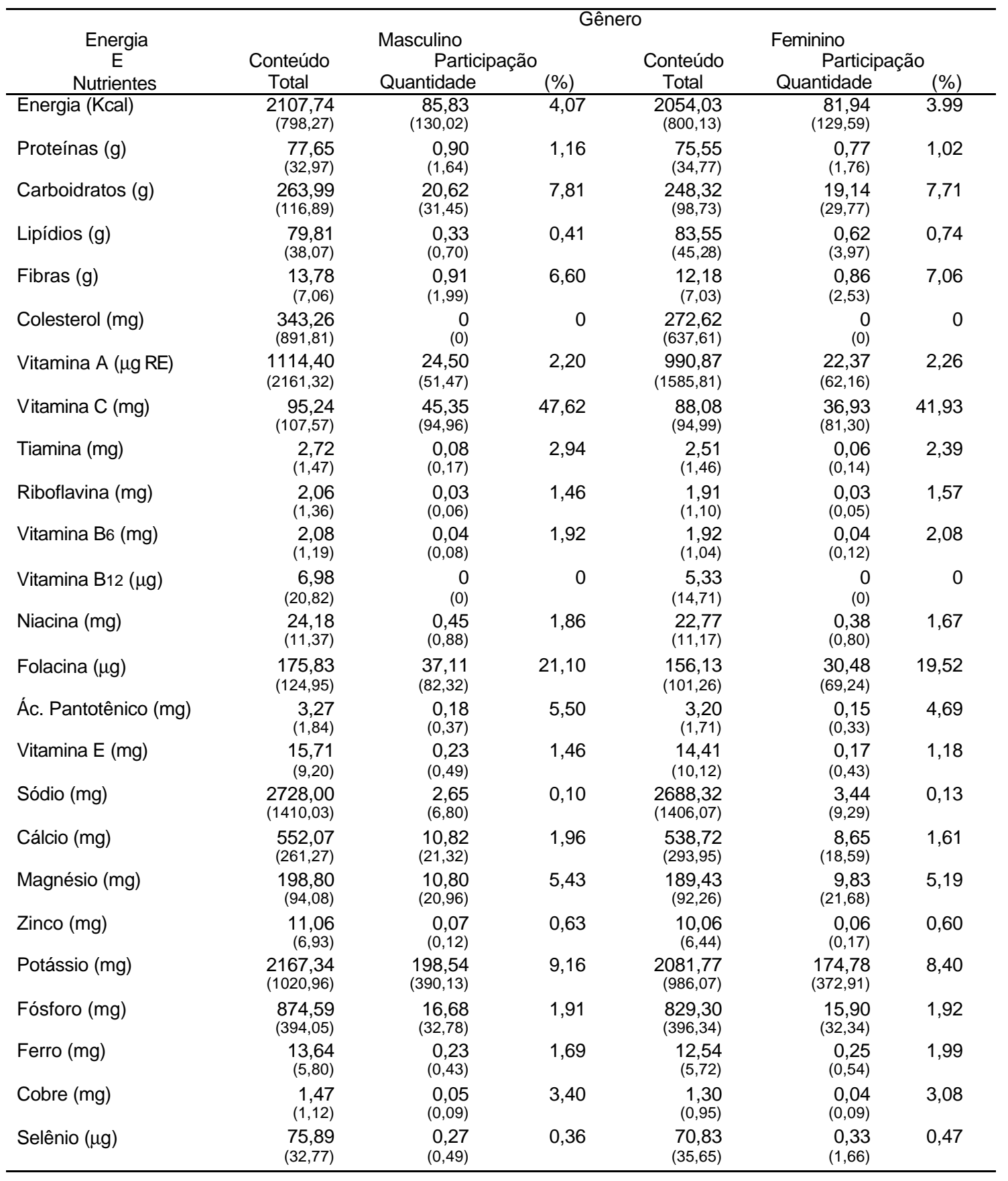

Nota: os números entre parênteses são os desvios-padrão. 
Do exame dos resultados apresentados na Tabela 14, observa-se que a participação da energia e da maioria dos nutrientes, provenientes das frutas, é ligeiramente maior para os meninos. Vale notar que, do total de 25 itens considerados (energia e nutrientes) nas análises das dietas dos escolares, há predomínio de 14 itens (incluindo energia e nutrientes) que contribuíram de forma mais expressiva, quando se examina a situação dos escolares do gênero masculino.

Analisando a situação das alunas, verifica-se superioridade da participação na dieta, dos lipídios, fibras, vitamina $A$, tiamina, riboflavina, vitamina B6, sódio, ferro e selênio, provenientes das frutas.

Embora as análises elaboradas, tendo por base os dados das Tabelas 13 e 14 não visem avaliar a contribuição de frutas e hortaliças para o atendimento das necessidades nutricionais, é interessante verificar que as meninas exibiram dietas, com maior participação relativa dos nutrientes provenientes de hortaliças, enquanto que para os meninos, a maior participação dos nutrientes foram originadas das frutas.

No município de São Paulo os escolares revelaram consumir uma quantidade de verduras, legumes e frutas, considerada insuficiente para atender æ̀ recomendações nutricionais de vitamina $A$ e outros nutrientes, conforme preconizado nas RDAs (Oliveira et al., 1998).

\subsubsection{Análise qualitativa}

Conforme descrito anteriormente, na presente pesquisa pretendeu-se, também, descrever a participação dos macronutrientes (carboidratos, lipídios e proteínas) no Valor Energético Total - VET da dieta dos escolares.

De acordo com os parâmetros preconizados pela National Academy of Sciences (2002), para indivíduos com idade entre 4 e 18 anos, os 
seguintes intervalos são considerados aceitáveis: 45\% a 65\% (carboidratos), 25\% a 35\% (lipídios) e 10\% a 30\% (proteínas).

É importante registrar que a participação dos macronutrientes no Valor Energético Total - VET da dieta foi considerada adequada, quando os seus três componentes, ou seja, carboidratos, lipídios e proteínas foram classificados, tendo como referência os intervalos preconizados pela National Academy of Sciences (2002).

Inversamente, a participação dos macronutrientes no VET foi classificada como inadequada quando pelo menos um dos componentes não se classificou no intervalo recomendado (National Academy of Sciences, 2002).

A seguir, são apresentadas as Tabelas (15 a 20), contendo os principais resultados obtidos.

Tabela 15. Distribuição dos escolares de acordo com a participação relativa dos macronutrientes no Valor Energético Total - VET e o gênero. Piracicaba, 2001.

\begin{tabular}{|c|c|c|c|c|c|c|}
\hline \multirow{3}{*}{$\begin{array}{c}\text { Participação } \\
\text { dos } \\
\text { macronutrientes no VET }\end{array}$} & \multirow{2}{*}{\multicolumn{2}{|c|}{ Observações }} & \multicolumn{4}{|c|}{ Gênero } \\
\hline & & & \multicolumn{2}{|c|}{ Masculino } & \multicolumn{2}{|c|}{ Feminino } \\
\hline & $\mathrm{n}^{0}$ & $\%$ & $\mathrm{n}^{0}$ & $\%$ & $\mathrm{n}^{\mathbf{0}}$ & $\%$ \\
\hline Adequada & 76 & 36,19 & 40 & 38,10 & 36 & 34,29 \\
\hline Inadequada & 134 & 63,81 & 65 & 61,90 & 69 & 65,71 \\
\hline TOTAL & 210 & 100,00 & 105 & 100,00 & 105 & 100,00 \\
\hline
\end{tabular}

$\chi^{2}=0,33$, com 1 grau de liberdade, não-significativo.

$\chi^{2}(\mathrm{MH})=0,33$, com 1 grau de liberdade, não-significativo.

A Tabela 15 revela que não foi possível constatar associação estatisticamente significativa entre as variáveis consideradas, ou seja, participação dos macronutrientes no VET e gênero dos escolares.

Analisando-se esses resultados, verifica-se que, tendo por base a amostra $(n=210), 36,19 \%$ dos alunos apresentaram dietas adequadas quanto 
a participação dos macronutrientes no VET. No entanto, a maioria $(63,81 \%)$ dos alunos tiveram suas dietas consideradas inadequadas, quando se considerou, conforme descrito, a participação conjunta dos três macronutrientes no VET

Nota-se também que $61,90 \%$ dos meninos tiveram suas dietas avaliadas como inadequadas, enquanto a proporção foi ligeiramente superior $(65,71 \%)$ para as meninas.

Segundo Monteiro et al. (2000), vale registrar que no período compreendido entre os anos de 1988 e 1996, houve um aumento na participação relativa de lipídios na dieta das famílias das regiões Norte e Nordeste do Brasil e uma diminuição no consumo de carboidratos.

De acordo com uma pesquisa realizada pelo Instituto Sodexho para o Desenvolvimento da Qualidade de Vida no Cotidiano (2001), constatouse que meninas tinham uma alimentação mais equilibrada, ingerindo alimentos naturais, enquanto que os meninos apresentavam uma dieta mais rica em energia. Também foi constatado que as meninas consumiam duas vezes mais frutas, vegetais e laticínios do que ingeriam os meninos. Quando os autores analisaram o consumo de carnes e carboidratos, concluíram que os meninos revelaram ingestão três vezes maior, quando comparada com os resultados obtidos para as meninas.

Tabela 16. Distribuição dos escolares de acordo com a participação relativa dos macronutrientes no Valor Energético Total - VET e estratos de idade. Piracicaba, 2001.

\begin{tabular}{|c|c|c|c|c|c|c|}
\hline \multirow{2}{*}{$\begin{array}{c}\text { Participação } \\
\text { dos } \\
\text { macronutrientes no VET }\end{array}$} & \multirow{2}{*}{\multicolumn{2}{|c|}{ Observações }} & \multicolumn{4}{|c|}{ Estratos de idade (em anos) } \\
\hline & & & & & & \\
\hline & & & & & & 210 \\
\hline Adequada & 76 & 36,19 & 18 & 43,90 & 58 & 34,32 \\
\hline Inadequada & 134 & 63,81 & 23 & 56,10 & 111 & 65,68 \\
\hline TOTAL & 210 & 100,00 & 41 & 100,00 & 169 & 100,00 \\
\hline
\end{tabular}

$\chi^{2}=1,31$, com 1 grau de liberdade, não-significativo.

$\chi^{2}(\mathrm{MH})=1,31$, com 1 grau de liberdade, não-significativo. 
Examinando os resultados da Tabela 16, nota-se que não houve associação estatisticamente significativa entre a participação dos macronutrientes no VET e diferentes estratos de idade dos escolares.

Porém, constata-se que entre os alunos da faixa etária de 7 a 10 anos, 43,90\% apresentaram uma dieta adequada, enquanto o grupo de indivíduos mais velhos (11 a 14 anos), revelou uma proporção (34,32\%) de adequação no tocante àparticipação dos macronutrientes no VET.

Essa inadequação $(65,68 \%)$ da dieta dos escolares de maior idade pode ser explicada tendo por base as considerações tecidas por Caroba (2002). $\mathrm{O}$ referido autor registra que os adolescentes para se integrarem socialmente incorporam, preferencialmente, os hábitos alimentares adotados pelo grupo de amigos. Com elevada freqüência no novo padrão de consumo, predominam de forma acentuada, os alimentos ricos em energia e lipídios, como pizza, hambúrguer, batata frita e salgadinhos tipo chips.

Tabela 17. Distribuição dos escolares de acordo com a participação relativa dos macronutrientes no Valor Energético Total - VET e os percentis do Índice de Massa Corporal - IMC. Piracicaba, 2001.

\begin{tabular}{|c|c|c|c|c|c|c|c|c|}
\hline \multirow{2}{*}{$\begin{array}{c}\text { Participação } \\
\text { dos } \\
\text { macronutrientes } \\
\text { no VET } \\
\end{array}$} & \multicolumn{2}{|c|}{ Observações } & \multicolumn{4}{|c|}{$\begin{array}{c}\text { Estado Nutricional } \\
15^{\circ} \mathrm{P} \leq \mathrm{IMC}< \\
85^{\circ} \mathrm{P}\end{array}$} & \multicolumn{2}{|c|}{$I M C \geq 85^{\circ} \mathrm{P}$} \\
\hline & $\mathrm{n}^{0}$ & $\%$ & $\mathrm{n}^{0}$ & $\%$ & $\mathrm{n}^{\circ}$ & $\%$ & $\mathrm{n}^{0}$ & $\%$ \\
\hline Adequada & 76 & 36,19 & 5 & $\begin{array}{l}23,81 \\
(6,60)\end{array}$ & 41 & $\begin{array}{r}34,75 \\
(53,90)\end{array}$ & 30 & $\begin{array}{r}42,25 \\
(39,50)\end{array}$ \\
\hline Inadequada & 134 & 63,81 & 16 & $\begin{array}{r}76,19 \\
(11,90)\end{array}$ & 77 & $\begin{array}{r}65,25 \\
(57,50)\end{array}$ & 41 & $\begin{array}{r}57,75 \\
(30,60)\end{array}$ \\
\hline TOTAL & 210 & 100,00 & 21 & $(10,00)$ & 118 & $(56,20)$ & 71 & $(33,80)$ \\
\hline
\end{tabular}

$\chi^{2}=2,63$, com 2 graus de liberdade, não-significativo.

$\chi^{2}(\mathrm{MH})=2,57$, com 1 grau de liberdade, significativo a $10 \%$.

Nota: Os números entre parênteses são os percentuais em relação ao total observado na linha.

Examinando os resultados encontrados na Tabela 17, observa-se que do total de alunos $(n=21)$ classificados com IMC $<15^{\circ} \mathrm{P}$ (baixo peso), 
$76,19 \%$ tiveram sua dieta classificada como inadequada quanto a participação dos macronutrientes no VET.

Merece atenção o fato do grupo classificado com IMC $\geq 85^{\circ} \mathrm{P}$ (sobrepeso), ou seja, 71 escolares (33,8\% do total, $n=210$ observações), apenas $42,25 \%$ tiveram sua dieta classificada como adequada. Inversamente, a maioria $(57,75 \%)$ revelou inadequação, quando se analisou a participação dos três macronutrientes no VET.

Tabela 18. Distribuição dos escolares de acordo com a participação relativa dos macronutrientes no Valor Energético Total - VET e estratos de renda familiar per capita. Piracicaba, 2001.

\begin{tabular}{|c|c|c|c|c|c|c|c|c|}
\hline \multirow{3}{*}{$\begin{array}{c}\text { Participação } \\
\text { dos } \\
\text { macronutrientes } \\
\text { no VET }\end{array}$} & \multirow{2}{*}{\multicolumn{2}{|c|}{ Observações }} & \multicolumn{6}{|c|}{ Estratos de renda familiar per capita (em reais) } \\
\hline & & & & 0,00 & 200,0 & 400,00 & &, 00 \\
\hline & $\mathrm{n}^{\circ}$ & $\%$ & $n^{\circ}-$ & $\%$ & $\mathrm{n}^{\circ}$ & $\%$ & $\mathrm{n}^{\circ}$ & $\%$ \\
\hline Adequada & 67 & 36,80 & 45 & 38,14 & 18 & 34,62 & 4 & 33,33 \\
\hline Inadequada & 115 & 63,20 & 73 & 61,86 & 34 & 65,38 & 8 & 66,67 \\
\hline TOTAL & 182 & 100,00 & 118 & 100,00 & 52 & 100,00 & 12 & 100,00 \\
\hline
\end{tabular}

$\chi^{2}=0,26$, com 2 graus de liberdade, não-significativo.

$\chi^{2}(\mathrm{MH})=0,25$, com 1 grau de liberdade, não-significativo.

Nota: $\quad$ integram as análises, as informações de 182 questionários, em decorrência da não devolução, pelas famílias de 10 questionários e omissão, por 8 entrevistados, da resposta para a questão específica sobre rendimentos.

Tendo por base os dados da Tabela 18, nota-se que a maior proporção $(66,67 \%)$ de escolares, cujas dietas se revelaram inadequadas quanto a participação relativa dos macronutrientes no VET, pertencem ao grupamento com maior renda per capita (superior a $R \$ 400,00$ ).

Quando se analisa a situação inversa, isto é, o grupamento com menor rendimento per capita ( $\leq \mathrm{R} \$ 200,00$ ) é possível observar que $61,86 \%$ dos escolares tiveram suas dietas classificadas como inadequadas. Ressalta-se que trata-se de menor percentagem $(61,86 \%)$ de inadequação, quando se compara com a proporção observada $(65,38 \%)$ entre os escolares pertencentes ao 
intervalo intermediário de renda e, o percentual é ainda mais elevado $(66,67 \%)$, quando se examina os dados do grupo de maior rendimento per capita.

No entanto os testes estatísticos adotados não confirmaram a existência de associação entre as variáveis consideradas.

Tabela 19. Distribuição dos escolares de acordo com a participação relativa dos macronutrientes no Valor Energético Total - VET e escolaridade da mãe. Piracicaba, 2001.

\begin{tabular}{|c|c|c|c|c|c|c|c|c|}
\hline \multirow{3}{*}{$\begin{array}{c}\text { Participação } \\
\text { dos } \\
\text { macronutrientes } \\
\text { no VET } \\
\end{array}$} & \multirow{2}{*}{\multicolumn{2}{|c|}{ Escolares }} & \multicolumn{6}{|c|}{ Escolaridade da mãe (anos de estudo) } \\
\hline & & & \multicolumn{2}{|c|}{$0 \vdash 4$} & \multicolumn{2}{|c|}{$5 \vdash 8$} & \multicolumn{2}{|c|}{$\geq 9$} \\
\hline & $\mathrm{n}^{\circ}$ & $\%$ & $\mathrm{n}^{0}$ & $\%$ & $\mathrm{n}^{\circ}$ & $\%$ & $\mathrm{n}^{0}$ & $\%$ \\
\hline Adequada & 71 & 36,6 & 29 & $\begin{array}{r}40,9 \\
(41,4)\end{array}$ & 25 & $\begin{array}{r}35,2 \\
(34,7)\end{array}$ & 17 & $\begin{array}{r}23,9 \\
(32,7)\end{array}$ \\
\hline Inadequada & 123 & 63,4 & 41 & $\begin{array}{r}33,4 \\
(58,6)\end{array}$ & 47 & $\begin{array}{r}38,2 \\
(65,3)\end{array}$ & 35 & $\begin{array}{r}28,4 \\
(67,3)\end{array}$ \\
\hline TOTAL & 194 & 100,0 & 70 & {$[36,1]$} & 72 & {$[37,1]$} & 52 & {$[26,8]$} \\
\hline
\end{tabular}

$\chi^{2}=1,16$, com 2 graus de liberdade, não-significativo.

$\chi^{2}(\mathrm{MH})=1,05$, com 1 grau de liberdade, não-significativo.

Nota: - s análises foram elaboradas, tendo por base as respostas válidas, obtidas para 194 escolares.

- os números entre colchetes são os percentuais relativos ao total $(n=194)$ observado na linha.

- os números entre parênteses são os percentuais em relação ao total observado na coluna.

Examinando os dados da Tabela 19 , verifica-se que $36,1 \%$ das mães $(n=70)$, dos escolares, possuíam até quatro anos de estudo. Quando se analisa a classificação da participação dos macronutrientes na dieta de seus filhos, nota-se que a maioria $(58,6 \%)$ foi considerada inadequada.

No grupamento, formado pelas mães com maior nível de escolaridade (pelo menos igual a nove anos de estudo), a situação é similar à observada $(58,6 \%)$ no grupo com menor escolaridade, ou seja, maior proporção $(67,3 \%)$ das dietas dos escolares, foram classificadas como inadequadas.

Os testes de qui-quadrado revelam que não há associação, estatisticamente significativa, entre as variáveis consideradas. 
Nesta pesquisa, julgou-se pertinente à inclusão das análises envolvendo a participação dos macronutrientes na dieta e a atividade profissional da mãe do escolar.

Os resultados são apresentados na Tabela 20, mostrada a seguir.

Tabela 20. Distribuição dos escolares de acordo com a participação relativa dos macronutrientes no Valor Energético Total - VET e a atividade profissional da mãe. Piracicaba, 2001.

\begin{tabular}{|c|c|c|c|c|c|c|c|c|}
\hline \multirow{3}{*}{$\begin{array}{l}\text { Participação } \\
\text { dos } \\
\text { macronutrientes } \\
\text { no VET } \\
\end{array}$} & \multirow{2}{*}{\multicolumn{2}{|c|}{ Escolares }} & \multicolumn{6}{|c|}{ Atividade profissional da mãe (fora do domicílio) } \\
\hline & & & \multicolumn{2}{|c|}{ SIM } & \multicolumn{2}{|c|}{ NÃO } & \multicolumn{2}{|c|}{$\begin{array}{l}\text { Desemprego } \\
\text { recente }\end{array}$} \\
\hline & $\mathrm{n}^{\circ}$ & $\%$ & $\mathrm{n}^{\circ}$ & $\%$ & $\mathrm{n}^{\circ}$ & $\%$ & $\mathrm{n}^{\circ}$ & $\%$ \\
\hline Adequada & 71 & 36,0 & 24 & $\begin{array}{r}33,8 \\
(28,9)\end{array}$ & 33 & $\begin{array}{r}46,5 \\
(38,8)\end{array}$ & 14 & $\begin{array}{r}19,7 \\
(48,3)\end{array}$ \\
\hline Inadequada & 126 & 64,0 & 59 & $\begin{array}{r}46,8 \\
(71,1)\end{array}$ & 52 & $\begin{array}{r}41,3 \\
(61,2)\end{array}$ & 15 & $\begin{array}{r}11,9 \\
(51,7)\end{array}$ \\
\hline TOTAL & 197 & 100,0 & 83 & {$[42,1]$} & 85 & {$[43,2]$} & 29 & {$[14,7]$} \\
\hline
\end{tabular}

$\chi^{2}=3,99$, com 2 graus de liberdade, não-significativo.

$\chi^{2}(\mathrm{MH})=3,98$, com 1 grau de liberdade, significativo a $5 \%$.

Nota: As análises foram elaboradas, tendo por base as respostas válidas, obtidas para 197 escolares.

- os números entre colchetes são os percentuais relativos ao total $(n=197)$ observado na linha.

- os números entre parênteses são os percentuais em relação ao total observado na coluna.

É interessante notar inicialmente que $42,1 \%$ das mães $(n=83)$,

para as quais se dispõe de informações válidas, informaram que trabalham fora do domicílio.

Ao analisar a participação dos macronutrientes na dieta dos escolares, filhos das referidas mães, observa-se que proporção inferior a $30 \%$, das dietas, revelou adequação quanto aos carboidratos, lipídios e proteínas.

Entre o grupo de mães que não trabalham (fora do domicílio), o percentual de filhos (escolares) com dietas classificadas como adequadas revela aumento de cerca de $10 \%$, ou seja, alcança $38,8 \%$.

Note-se também, que os testes não confirmaram associação entre as variáveis. 
Nesta dissertação, especial atenção será dedicada às análises que envolvem, entre outros, os dados relativos ao consumo de hortaliças pela família dos escolares.

Vale embrar que, de acordo com Angelis (1999) o consumo de vegetais por crianças e adolescentes, refletem, em parte, o hábito da família. No entanto, reconhece-se que esse não é o único condicionante do consumo.

Visando conhecer a freqüência de citações relativas ao consumo de hortaliças, no domicílio, elaborou-se a Tabela 21.

Tabela 21. Distribuição das citações dos pais (ou responsáveis) de acordo com a freqüência de consumo de hortaliças, no domicílio da família. Piracicaba, 2001

\begin{tabular}{lrr}
\hline \multicolumn{1}{c}{ Freqüência de consumo semanal } & nº & \multicolumn{1}{c}{ Citações } \\
\hline $1 \longmapsto \mid 2$ & 42 & 21,0 \\
3 & 30 & 15,0 \\
4 & 30 & 15,0 \\
$5 \longmapsto \mid 6$ & 96 & 48,0 \\
Não consome & 2 & 1,0 \\
TOTAL & 200 & 100,0 \\
\hline
\end{tabular}

Nota: as análises foram elaboradas tendo por base 200 observações válidas.

Note-se que a maior proporção $(48,0 \%)$ de citações (praticamente a metade) dos pais refere-se ao consumo de hortaliças de, pelo menos, cinco vezes na semana, seguido pelo consumo máximo de duas vezes semanais (de acordo com $21 \%$ de citações).

Pesquisa realizada por Borguini (2002), avaliando a freqüência de consumo de tomates, por moradores da cidade de Piracicaba, mostrou que $64,4 \%$ do grupo entrevistado revelou que consumiam tomate diariamente, $30,4 \%$ semanalmente e somente, $5,1 \%$ revelaram consumir eventualmente o alimento. A elevada freqüência de consumo de tomates entre os participantes da referida pesquisa, confirma os dados da POF de 1995 - 1996, na qual esta hortaliça aparece em destaque como a mais consumida pela população das 
regiões metropolitanos do Brasil. Visando conhecer a relação entre as variáveis de consumo de hortaliças e os estratos de rendimentos familiares, elaborou-se a Tabela 22 apresentada a seguir. 
Tabela 22. Distribuição das citações relativas ao consumo de hortaliças pelas famílias dos escolares, de acordo com os estratos de renda familiar per capita. Piracicaba, 2001.

\begin{tabular}{|c|c|c|c|c|c|c|c|c|c|c|c|c|}
\hline \multirow{3}{*}{$\begin{array}{l}\text { Estratos de } \\
\text { renda familiar } \\
\text { per capita } \\
\text { (em reais) }\end{array}$} & \multirow{2}{*}{\multicolumn{2}{|c|}{ Observações }} & & & & & \multicolumn{6}{|c|}{ Freqüência semanal de consumo } \\
\hline & & & \multicolumn{2}{|c|}{$1 X$} & \multicolumn{2}{|c|}{$2 x$} & \multicolumn{2}{|c|}{$3 x$} & \multicolumn{2}{|c|}{$4 X$} & \multicolumn{2}{|c|}{$5 \times$} \\
\hline & $\mathrm{n}^{\circ}$ & $\%$ & $\mathrm{n}^{\circ}$ & $\%$ & $\mathrm{n}^{0}$ & $\%$ & $\mathrm{n}^{0}$ & $\%$ & $\mathrm{n}^{\circ}$ & $\%$ & $\mathrm{n}^{\circ}$ & $\%$ \\
\hline$\leq 200,00$ & 109 & 63,0 & 13 & $\begin{array}{r}11,9 \\
(68,4)\end{array}$ & 15 & $\begin{array}{r}13,8 \\
(83,4)\end{array}$ & 19 & $\begin{array}{r}17,4 \\
(67,9)\end{array}$ & 18 & $\begin{array}{r}16,5 \\
(69,2)\end{array}$ & 20 & $\begin{array}{r}18,4 \\
(62,5)\end{array}$ \\
\hline $200-400,00$ & 52 & 30,1 & 4 & $\begin{array}{r}7,7 \\
(21,1)\end{array}$ & 2 & $\begin{array}{r}3,8 \\
(11,2)\end{array}$ & 5 & $\begin{array}{r}9,6 \\
(17,9)\end{array}$ & 8 & $\begin{array}{r}15,4 \\
(30,8)\end{array}$ & 12 & $\begin{array}{r}23,1 \\
(37,5)\end{array}$ \\
\hline$>400,00$ & 12 & 6,9 & 2 & $\begin{array}{r}16,6 \\
(10,5)\end{array}$ & 1 & $\begin{array}{r}8,4 \\
(5,4)\end{array}$ & 4 & $\begin{array}{r}33,3 \\
(14,2)\end{array}$ & 0 & $\begin{array}{r}0,0 \\
(0,0)\end{array}$ & 0 & $\begin{array}{r}0,0 \\
(0,0)\end{array}$ \\
\hline TOTAL & 173 & 100,0 & 19 & {$[11,0]$} & 18 & {$[10,4]$} & 28 & {$[16,2]$} & 26 & {$[15,0]$} & 32 & {$[18,5]$} \\
\hline
\end{tabular}

$\chi^{2}=20,04$, com 12 graus de liberdade, significativo a $10 \%$.

$\chi^{2}(\mathrm{MH})=2,7$, com 1 grau de liberdade, significativo a $10 \%$.

Nota: - as análises foram elaboradas, tendo por base 173 observações válidas.

- os números entre parênteses são os percentuais em relação ao total observado na coluna.

- os números entre colchetes são os percentuais em relação ao total observado na linha. 
Tendo por base os resultados da Tabela 22, nota-se que $11 \%$ dos entrevistados, informaram que as famílias consomem hortaliças uma vez por semana. Entre esses $68,4 \%$, pertenciam ao grupo de menor renda familiar per capita ( $\leq R \$ 200,00$ ), enquanto apenas $10,5 \%$, possuíam renda acima de $\mathrm{R} \$ 400,00$.

Ainda com relação aos dados da Tabela 22, quando se analisa os percentuais de freqüência de consumo de hortaliças por três vezes na semana, observa-se que o menor percentual $(14,2 \%)$ é verificado entre os indivíduos que possuíam maior renda per capita. Por outro lado, a maior proporção verificada $(67,9 \%)$ ocorre no grupamento mais pobre $(\leq R \$ 200,00)$.

Os testes revelaram que há, entre as variáveis, associação estatisticamente significativa ao nível de $10 \%$.

A associação entre consumo de alimentos de origem vegetal e renda fica clara, quando se verifica o estudo de Shimpton (1984), conduzida por meio de registro mensal de compras. $O$ autor mostra que as famílias de mais elevado poder aquisitivo adquiriram batatas, outros vegetais e frutas com mais freqüência do que as demais, e que a adequação do fornecimento de vitamina $A$ e $C$ era mais sensível ao efeito da renda do que os demais nutrientes.

Em Minas Gerais, de acordo com pesquisa (Lima et al., 1989) envolvendo 161 famílias da Zona da Mata, estratificadas em seis níveis de renda, o consumo per capita de alimentos de origem vegetal aumentou com o poder aquisitivo, ao mesmo tempo em que os alimentos como o arroz e o macarrão eram consumidos em maior quantidade nas famílias com menor poder aquisitivo.

Trabalho desenvolvido por Borguini (2002), analisando a freqüência de consumo de tomate e a renda familiar, mostrou que com exceção dos integrantes do grupamento com rendimentos inferiores a um salário mínimo, à totalidade dos demais participantes, ou seja, indivíduos com maior renda familiar, que registraram consumo diário, superou 50\%. Destaca-se ainda que para os estratos de renda familiar entre 7 a 10 e 11 a 15 salários mínimos, 
a freqüência de citações de consumo diário foi de $75 \%$ e $80 \%$, respectivamente. Os dados da POF (1995/ 1996) também revelaram menor freqüência de consumo entre as famílias com rendimentos entre um e dois salários mínimos mensais.

Observando os resultados, obtidos na presente pesquisa, referentes æ̀ citações do grupo de renda superior a $R \$ 400,00$, nota-se que a maior proporção $(41,7 \%)$ é encontrada, quando se considera o consumo de hortaliças pelo menos igual a 6 vezes/ semana.

Os resultados relativos à distribuição de citações referentes à opinião dos pais relativas æ̀ hortaliças apreciadas e consumidas pela família do escolar, foram organizados na Tabela 23. 
Tabela 23. Distribuição das citações da opinião dos pais (ou responsáveis) dos escolares, relativas às hortaliças apreciadas e consumidas pela família no domicílio. Piracicaba, 2001.

\begin{tabular}{lrrrr}
\hline \multicolumn{1}{c}{ Alimento } & \multicolumn{3}{c}{ SIM } & \multicolumn{3}{c}{ Opinião } & NÃO \\
& $\mathrm{n}^{0}$ & $\%$ & $\mathrm{n}^{\circ}$ & $\%$ \\
\hline Alface & 190 & 95,5 & 69 & 4,5 \\
Rúcula & 89 & 44,7 & 110 & 55,3 \\
Couve & 85 & 42,7 & 114 & 57,3 \\
Tomate & 83 & 41,7 & 116 & 58,3 \\
Repolho & 71 & 35,7 & 128 & 70,3 \\
Escarola & 58 & 29,1 & 141 & 72,9 \\
Cenoura & 54 & 27,1 & 145 & 78,4 \\
Almeirão & 43 & 21,6 & 156 & 78,9 \\
Pepino & 42 & 21,1 & 157 & 81,9 \\
Couve-flor & 36 & 18,1 & 163 & 83,4 \\
Batata & 33 & 16,6 & 166 & 87,4 \\
Beterraba & 29 & 14,6 & 170 & 87,9 \\
Agrião & 25 & 12,6 & 174 & 91,5 \\
Brócolis & 24 & 12,1 & 175 & 92,5 \\
Abobrinha & 17 & 8,5 & 182 & 92,5 \\
Espinafre & 15 & 7,5 & 184 & 93,0 \\
Chuchu & 15 & 7,5 & 184 & 94,0 \\
Acelga & 14 & 7,0 & 185 & 95,0 \\
Vagem & 12 & 6,0 & 187 & 95,0 \\
Berinjela & 10 & 5,0 & 189 & 96,5 \\
Pimentão & 10 & 5,0 & 189 & 96,5 \\
Cebola & 7 & 3,5 & 192 & 97,0 \\
Cheiro-verde & 7 & 3,5 & 192 & 97,5 \\
Rabanete & 6 & 3,0 & 193 & 97,5 \\
Mandioca & 5 & 2,5 & 194 & \\
Quiabo & 5 & 2,5 & 194 & \\
Jiló & 4 & 2,0 & 195 & \\
\hline
\end{tabular}

Nota: as análises foram elaboradas, tendo por base 210 observações válidas.

É interessante notar que classifica-se na primeira posição, a alface (190 citações) ou seja, 95,5\% dos entrevistados reconheciam que a hortaliça era um alimento que atendia os hábitos e/ ou preferências da família. Pode-se atribuir o consumo desta hortaliça a fatores como o custo relativamente baixo, fácil preparação e por ser de alta disponibilidade ao consumidor, isto é, encontrada em diversos pontos de comercialização. 
Vale destacar também a drástica diferença existente entre o primeiro e o segundo lugar (rúcula) na lista de hortaliças. Os alimentos como couve e tomate, em média, revelaram cerca de $42 \%$ das citações.

Especificamente quanto a composição do tomate, verifica-se que, do ponto de vista nutricional, ele pode ser considerado como uma boa fonte de vitamina C. No entanto, os demais componentes se apresentam em teores, freqüentemente menores (Borguini, 2002).

Com relação aos fitonutrientes, o carotenóide mais abundante no tomate é o licopeno, que proporciona coloração vermelha aos vegetais e é encontrado, também, em frutas como goiaba, melancia, pitanga, mamão papaia e damasco.

Ainda de acordo com a Tabela 23, entre os alimentos menos consumidos, observa-se o rabanete $(3,0 \%)$, mandioca e quiabo $(2,5 \%)$, e jiló $(2,0 \%)$. Pode-se inferir que a pequena aceitação desses vegetais decorra da maior dificuldade de preparo (no caso da mandioca) e do gosto amargo percebido durante o consumo de jiló.

Os resultados envolvendo as análises de associação, entre as variáveis escolaridade materna e consumo de hortaliças, podem ser observados na Tabela 24. 
Tabela 24. Distribuição das citações relativas ao consumo de hortaliças pelas famílias dos escolares, de acordo com a escolaridade materna. Piracicaba, 2001.

\begin{tabular}{|c|c|c|c|c|c|c|c|c|c|c|c|c|}
\hline \multirow{3}{*}{$\begin{array}{l}\text { Escolaridade } \\
\text { da mãe } \\
\text { (em anos de } \\
\text { estudo) }\end{array}$} & \multirow{2}{*}{\multicolumn{2}{|c|}{ Observações }} & & & & & \multicolumn{6}{|c|}{ Freqüência semanal de consumo } \\
\hline & & & \multicolumn{2}{|c|}{$1 X$} & \multicolumn{2}{|c|}{$2 x$} & \multicolumn{2}{|c|}{$3 x$} & \multicolumn{2}{|c|}{$4 X$} & \multicolumn{2}{|c|}{$5 X$} \\
\hline & $\mathrm{n}^{0}$ & $\%$ & $n^{0}$ & $\%$ & $n^{0}$ & $\%$ & $n^{0}$ & $\%$ & $\mathrm{n}^{\circ}$ & $\%$ & $\mathrm{n}^{\circ}$ & $\%$ \\
\hline $0 \vdash 4$ & 70 & 36,1 & 7 & $\begin{array}{r}10,0 \\
(35,0)\end{array}$ & 12 & $\begin{array}{r}17,1 \\
(60,0)\end{array}$ & 12 & $\begin{array}{r}17,1 \\
(42,9)\end{array}$ & 6 & $\begin{array}{r}8,6 \\
(20,0)\end{array}$ & 18 & $\begin{array}{r}25,7 \\
(45,0)\end{array}$ \\
\hline $5 \vdash 8$ & 72 & 37,1 & 10 & $\begin{array}{r}13,9 \\
(50,0)\end{array}$ & 4 & $\begin{array}{r}5,5 \\
(20,0)\end{array}$ & 12 & $\begin{array}{r}16,7 \\
(42,9)\end{array}$ & 13 & $\begin{array}{r}18,1 \\
(43,3)\end{array}$ & 14 & $\begin{array}{r}19,4 \\
(35,0)\end{array}$ \\
\hline$\geq 9$ & 52 & 26,8 & 3 & $\begin{array}{r}5,8 \\
(15,0)\end{array}$ & 4 & $\begin{array}{r}7,7 \\
(20,0)\end{array}$ & 4 & $\begin{array}{r}7,7 \\
(14,2)\end{array}$ & 11 & $\begin{array}{r}21,1 \\
(36,6)\end{array}$ & 8 & $\begin{array}{r}15,4 \\
(20,0)\end{array}$ \\
\hline TOTAL & 194 & 100,0 & 20 & {$[10,3]$} & 20 & {$[10,3]$} & 28 & {$[14,4]$} & 30 & {$[15,5]$} & 40 & {$[20,7]$} \\
\hline
\end{tabular}

$\chi^{2}=24,12$, com 12 graus de liberdade, significativo a $5 \%$.

$\chi^{2}(\mathrm{MH})=4,69$, com 1 grau de liberdade, significativo a $5 \%$.

Nota: - as análises foram elaboradas, tendo por base 194 observações válidas.

- os números entre parênteses são os percentuais em relação ao total observado na coluna.

- os números entre colchetes são os percentuais em relação ao total observado na linha. 
É muito clara a variação da freqüência de citações do consumo de hortaliças pelas famílias dos escolares, quando se considera o efeito da escolaridade materna.

Quando se considerou o total de observações $(n=20)$ referentes à citações de consumo apenas de uma vez por semana, nota-se que $35 \%$ dos entrevistados pertencem ao grupamento de mães com menor escolaridade.

É interessante frisar que entre as famílias que afirmaram manter o hábito de consumir hortaliças seis ou mais vezes por semana $(27,8 \%)$, o maior percentual de citações de freqüência de consumo desse do alimento $(40,7 \%)$, foi observado ro grupo de mães com escolaridade pelo menos igual a nove anos.

Ainda com relação à referida freqüência semanal de consumo de hortaliças (seis vezes ou mais), 24,1\% pertenciam ao grupo com escolaridade, de no máximo quatro anos (de estudo).

Entre aqueles que afirmaram não consumir hortaliças, a totalidade (100\%) se encontra em famílias, cujas mães revelaram escolaridade inferior a quatro anos de estudo. Vale observar, no entanto, que trata-se de um número muito baixo de citações $(n=2)$.

Trabalho desenvolvido por Borguini (2002), considerando a freqüência de consumo de tomate e o nível de escolaridade, dos entrevistados, revelou uma maior freqüência de consumo diário entre os indivíduos que possuíam o segundo grau completo, enquanto que aqueles que não completaram o segundo grau, $100 \%$ registraram que consomem o tomate, uma vez por semana.

As citações dos escolares, de acordo com as preferências, relativas æ̀ hortaliças consumidas no domicílio, foram organizadas na Tabela 25 , mostrada a seguir. 
Tabela 25. Distribuição das citações das preferências dos escolares, relativas às hortaliças consumidas no domicílio. Piracicaba, 2001.

\begin{tabular}{lrrrr}
\hline \multicolumn{1}{c}{ Alimento } & \multicolumn{3}{c}{ Opinião } & NÃO \\
& $n^{\circ}$ - & \% & $n^{\circ}$ & $\%$ \\
\hline Alface & 197 & 93,8 & 13 & 6,2 \\
Tomate & 133 & 63,3 & 77 & 36,7 \\
Cenoura & 84 & 40,0 & 126 & 60,0 \\
Repolho & 55 & 26,2 & 155 & 73,8 \\
Batata & 54 & 25,7 & 156 & 74,3 \\
Pepino & 52 & 24,8 & 158 & 75,2 \\
Beterraba & 47 & 22,4 & 163 & 77,6 \\
Couve & 44 & 21,0 & 166 & 79,0 \\
Rúcula & 39 & 18,6 & 171 & 81,4 \\
Couve-flor & 23 & 11,0 & 187 & 89,0 \\
Cebola & 20 & 9,5 & 190 & 90,5 \\
Almeirão & 18 & 8,6 & 192 & 91,4 \\
Escarola & 13 & 6,2 & 197 & 93,8 \\
Agrião & 12 & 5,7 & 198 & 94,3 \\
Brócolis & 12 & 5,7 & 198 & 94,3 \\
Rabanete & 10 & 4,8 & 200 & 95,2 \\
Espinafre & 8 & 3,8 & 202 & 96,2 \\
Vagem & 5 & 2,4 & 205 & 97,6 \\
Cheiro-verde & 3 & 1,4 & 207 & 98,6 \\
Berinjela & 3 & 1,4 & 207 & 98,6 \\
Escarola & 2 & 1,0 & 208 & 99,0 \\
Quiabo & 2 & 1,0 & 208 & 99,0 \\
\hline
\end{tabular}

Nota: as análises foram elaboradas, tendo por base 210 observações válidas.

Observa-se que há elevada preferência dos escolares por alface (93,8\% de citações), seguida pelo tomate $(63,3 \%)$.

É interessante registrar que, com freqüência, a alface e o tomate são consumidos juntos em saladas, que tradicionalmente são preparadas, nos domicílios, pelas famílias.

Outro dado que merece destaque é a freqüência de citações relativas a cenoura, considerada um alimento rico em $\beta$-caroteno e, portanto, ao ser consumida rotineiramente pelos escolares pode contribuir para 0 atendimento da demanda do referido nutriente. 
Examinando os dados da Tabela 25 verifica-se que a cenoura obteve $40 \%$ de citações, ocupando a terceira posição, entre 22 hortaliças registradas.

Ao se considerar as citações da vagem, nota-se que a mesma integra o grupo das cinco hortaliças que receberam o menor número de $(2,4 \%)$. No entanto, os testes de análise sensorial envolvendo cenoura e vagem (minimamente processadas) apresentados nesta dissertação revelaram aceitação mais elevada.

Tendo em vista o atendimento de um dos objetivos da presente pesquisa, buscou-se conhecer, também, as preferências dos escolares por hortaliças especificamente no que diz respeito ao consumo no âmbito escolar. Esclarece-se que a referida possibilidade de consumo, invariavelmente, ocorre por meio das refeições, distribuídas gratuitamente, pelo programa de merenda escolar.

Os resultados obtidos foram organizados na Tabela 26, mostrada a seguir. 
Tabela 26. Distribuição das citações das preferências dos escolares, relativas ao consumo de hortaliças na unidade de ensino. Piracicaba, 2001.

\begin{tabular}{|c|c|c|c|c|}
\hline \multirow{3}{*}{ Alimento } & \multicolumn{4}{|c|}{ Preferências } \\
\hline & & & & \\
\hline & $\mathrm{n}^{-0}$ & $\%$ & $n^{0}$ & $\%$ \\
\hline Cenoura & 66 & 31,4 & 144 & 68,6 \\
\hline Batata & 60 & 28,6 & 150 & 71,4 \\
\hline Tomate & 22 & 10,5 & 188 & 89,5 \\
\hline Chuchu & 20 & 9,5 & 190 & 90,5 \\
\hline Alface & 18 & 8,6 & 192 & 91,4 \\
\hline Repolho & 12 & 5,7 & 198 & 94,3 \\
\hline Abobrinha & 10 & 4,8 & 200 & 95,2 \\
\hline Cebola & 8 & 3,8 & 202 & 96,2 \\
\hline Vagem & 8 & 3,8 & 202 & 96,2 \\
\hline Pepino & 7 & 3,3 & 203 & 96,7 \\
\hline Rúcula & 6 & 2,9 & 204 & 97,1 \\
\hline Cheiro-verde & 4 & 1,9 & 206 & 98,1 \\
\hline Almeirão & 3 & 1,4 & 207 & 98.6 \\
\hline Couve-flor & 3 & 1,4 & 207 & 98,6 \\
\hline Couve & 2 & 1,0 & 208 & 99,0 \\
\hline Beterraba & 2 & 1,0 & 208 & 99,0 \\
\hline Rabanete & 2 & 1,0 & 208 & 99,0 \\
\hline Ervilha & 1 & 0,5 & 209 & 99,5 \\
\hline Acelga & 1 & 0,5 & 209 & 99,5 \\
\hline Agrião & 1 & 0,5 & 209 & 99,5 \\
\hline Espinafre & 1 & 0,5 & 209 & 99,5 \\
\hline Mandioca & 1 & 0,5 & 209 & 99,5 \\
\hline Pimentão & 1 & 0,5 & 209 & 99,5 \\
\hline
\end{tabular}

Nota: as análises foram elaboradas, tendo por base 210 observações válidas.

O dados da Tabela 26 revelam que as três hortaliças preferidas para consumo pelos escolares, no âmbito das unidades de ensino, são a cenoura $(31,4 \%)$, a batata $(28,6 \%)$ e o tomate $(10,5 \%)$. A alface, que nas análises anteriores recebeu elevado número de citações, neste caso foi registrada a sua preferência por apenas 18 alunos (8,6\%).

A vagem, que a exemplo da cenoura, também foi submetida à avaliação sensorial pelos escolares, recebeu menor percentual $(n=8)$ de citações. 
Entre os alimentos que receberam menor número de citações relativas à preferência, registradas pelos escolares, encontram-se a ervilha, acelga, agrião, espinafre, mandioca e pimentão (99,5\% de rejeição).

A Tabela 27, apresentada a seguir, reúne os resultados obtidos junto aos pais, quando se considerou a expectativa que os mesmos possuíam quanto ao consumo de hortaliças, pelos filhos, no caso das mesmas serem distribuídas pelo Programa de Merenda Escolar.

Tabela 27. Distribuição das citações dos pais (ou responsáveis) com relação à expectativa do consumo de hortaliças pelos filhos, no caso das mesmas integrarem os cardápios do Programa de Merenda Escolar. Piracicaba, 2001.

\begin{tabular}{lrr}
\hline \multicolumn{1}{c}{$\begin{array}{c}\text { Expectativa dos pais relacionados ao } \\
\text { consumo de hortaliças pelos filhos na } \\
\quad \text { escola }\end{array}$} & \multicolumn{2}{c}{ Citações } \\
\hline Sim & $\mathrm{n}^{\circ}$ & \multicolumn{1}{c}{$\%$} \\
Não & 121 & 60,5 \\
Não sabe informar & 25 & 12,5 \\
Não respondeu & 42 & 21,0 \\
TOTAL & 12 & 6,0 \\
\hline
\end{tabular}

Nota: análises elaboradas tendo por base 200 observações válidas.

É interessante notar que a maioria $(60,5 \%)$ dos pais acredita que os filhos consumirão as hortaliças, no caso das mesmas integrarem as refeições do PME. Tal registro parece indicar que os pais, conhecem os hábitos de comportamento dos filhos no que se refere, especificamente, o consumo de hortaliças.

Merece atenção, também, o percentual (21\%) de pais ou responsáveis que não souberam informar, revelando assim que não conseguem elaborar um prognóstico, no que se refere æ̀ reações dos filhos, frente à possibilidade de consumo de hortaliças, como integrantes das refeições gratuitas distribuídas na escola. 
Pesquisa realizada por Brandão (2000) solicitou aos escolares que aderiam ou não ao PME (mantido nas unidades de ensino de Campinas, SP),, que escolhessem quais alimentos gostariam de comer na merenda de sua escola, caso Ihes fosse dada esta opção. Observou-se que tanto os escolares que não aderiram, como os escolares que aderiam ao PME, apresentaram muita semelhança ao registrar a opção do alimento que incluiriam no cardápio. A grande surpresa foi a citação, por parte dos escolares, de grande número de alimentos como vegetais folhosos e não folhosos, arroz e feijão.

\subsection{Análise sensorial}

Nesta seção serão apresentados os resultados relativos a análise sensorial de hortaliças (cenoura e vagem) minimamente processadas.

Tabela 28. Distribuição dos escolares de acordo com a aceitabilidade das hortaliças minimamente processadas (cenoura e vagem) e 0 gênero. Piracicaba, 2001.

\begin{tabular}{|c|c|c|c|c|c|c|c|c|}
\hline \multirow[t]{2}{*}{ Gênero } & \multicolumn{2}{|c|}{ Total } & \multicolumn{2}{|c|}{ Gostou muito } & \multicolumn{2}{|c|}{ Gostou pouco } & \multicolumn{2}{|c|}{ Não gostou } \\
\hline & $\mathrm{n}^{0}$ & $\%$ & $\mathrm{n}^{0}$ & $\%$ & $\mathrm{n}^{0}$ & $\%$ & $\mathrm{n}^{0}$ & $\%$ \\
\hline Feminino & 105 & 50,0 & 59 & 56,19 & 28 & 26,67 & 18 & 17,14 \\
\hline Masculino & 105 & 50,0 & 63 & 60,00 & 38 & 36,19 & 4 & 3,81 \\
\hline Total & 210 & 100,0 & 122 & {$[58,10]$} & 66 & {$[31,43]$} & 22 & {$[10,47]$} \\
\hline
\end{tabular}

$\chi^{2}=10,56$, com 2 graus de liberdade significativo a $1 \%$.

$\chi^{2}(\mathrm{MH})=3,35$, com 1 grau de liberdade significativo a $10 \%$.

Nota: Os números entre colchetes são os percentuais em relação ao total ( $n=210)$ observado na linha.

Analisando-se os dados da Tabela 28 observa-se que $58,10 \%$ dos escolares gostaram muito das hortaliças minimamente processadas, e apenas $10,47 \%$ revelaram não gostar dos vegetais consumidos (cenoura e vagem).

É interessante notar que quando se examina a aceitabilidade, discriminando-se os escolares de acordo com o gênero, verifica-se que, 
enquanto $17,14 \%$ das meninas afirmaram "não gostar" das hortaliças minimamente processadas, apenas $3,81 \%$ dos meninos registraram a mesma opinião ("não gostar") sobre os vegetais. Percebe-se que o percentual de meninas que alegaram "não gostar" é bastante superior ao verificado entre os meninos. Os resultados parecem sugerir que as meninas se revelaram mais exigentes quando se trata de analisar ou selecionar os alimentos.

Análises similares, adotando a mesma metodologia e envolvendo escolares da rede pública de ensino do município paulista de Piedade revelou que $60,60 \%$ dos escolares gostaram muito das hortaliças minimamente processadas e, apenas, $0,60 \%$ não gostaram. A análise, levando-se em consideração o gênero dos escolares, revelou que a maioria $(65,5 \%)$ das meninas registrou gostar muito dos vegetais (cenoura e vagem) minimamente processados (Sasaki et al., 2001).

Os resultados da presente pesquisa apontam para uma aceitação expressiva da cenoura e vagem minimamente processadas entre os alunos da rede pública de ensino de Piracicaba.

Tendo por base os resultados, é possível inferir que os referidos alimentos podem se constituir em uma alternativa, quando incorporados ao cardápio de PME, para fornecimento, rotineiro æ̀s crianças, de alimentos de origem vegetal. Tal iniciativa poderá ser analisada, de forma criteriosa, pelos responsáveis pelo planejamento dos cardápios de programas e serviços de alimentação, dirigidos especialmente ao público jovem. A alternativa de inclusão desse tipo de alimento se revela atraente àmedida que dados obtidos junto aos alunos de escolas públicas tem mostrado, de forma geral reduzido consumo de hortaliças e frutas, quando se analisa o conteúdo por meio das refeições distribuídas gratuitamente durante a jornada de aula (Caroba, 2002; Silva, 1996 e Sturion, 2002).

A seguir, apresenta-se os resultados (Tabela 29) tendo por base as variáveis aceitabilidade das hortaliças minimamente processadas e a renda familiar per capita. 
Tabela 29. Distribuição dos escolares de acordo com a aceitabilidade das hortaliças minimamente processadas e a renda familiar per capita. Piracicaba, 2001.

\begin{tabular}{|c|c|c|c|c|}
\hline \multirow[t]{2}{*}{ Avaliação Sensorial } & \multicolumn{2}{|c|}{ Observações } & \multicolumn{2}{|c|}{$\begin{array}{c}\text { Renda Familiar per capita } \\
\text { (em reais) }\end{array}$} \\
\hline & № & $\%$ & $\begin{array}{c}\text { Média } \\
\text { (em reais) }\end{array}$ & Desvio padrão \\
\hline Gostou muito & 111 & 60,99 & 195,77 & 167,09 \\
\hline Gostou pouco & 53 & 29,12 & 217,98 & 164,00 \\
\hline Não gostou & 18 & 9,89 & 248,95 & 498,48 \\
\hline
\end{tabular}

Nota: Integram as análises as informações de 182 questionários, em decorrência da não devolução, pelas famílias, de 10 questionários e omissão, por 18 entrevistados, de resposta para a questão específica sobre rendimentos.

Analisando as informações da Tabela 29, é possível verificar que $60,99 \%$ dos alunos que registraram "gostar muito" dos vegetais minimamente processados, pertenciam às famílias que possuíam menor renda média familiar per capita. Cerca de $10 \%$ dos escolares com renda maior ( $\mathrm{R} \$ 248,95)$ declararam não gostar dos alimentos.

Dados obtidos por Sasaki et al. (2001) mostraram que a maior proporção de aceitação das hortaliças, durante a análise sensorial, foi registrada pelos escolares, cuja renda per capita situava-se entre $R \$ 80,00$ a $R \$ 160,00$, ou seja, o grupamento mais pobre.

Pode-se inferir que a boa aceitação por parte dos alunos pertencentes aos estratos de menor renda pode decorrer do fato dessas crianças e adolescentes não disporem de muitas opções de alimentos em suas casas e, em decorrência disso, recebem com maior facilidade as novas alternativas alimentares, de boa qualidade, que Ihes são apresentadas, por meio dos programas de alimentação, implementados nas unidades de ensino.

Vale lembrar que os alimentos minimamente processados apresentam cortes padronizados, uniformidade de cor, textura e sabor, sendo portanto, atrativos para o consumo.

Ainda com base nos resultados obtidos por meio da análise sensorial e, também, com o envolvimento dos dados sobre a participação 
relativa de energia e nutrientes (selecionados), provenientes de hortaliças e frutas, foram elaboradas as Tabelas 30 e 31.

Tabela 30. Participação relativa de energia e nutrientes (selecionados) provenientes das hortaliças consumidas pelos escolares da rede pública de ensino de acordo com a análise sensorial. Piracicaba, 2001.

\begin{tabular}{lrrr}
\hline $\begin{array}{l}\text { Energia e Nutrientes } \\
(\%)\end{array}$ & Gostou Muito & Gostou Pouco & Não Gostou \\
\hline Energia & & & 2,32 \\
& 4,77 & 3,70 & $(6,86)$ \\
Proteínas & $(9,45)$ & $(10,80)$ & 2,63 \\
& 6,20 & 4,26 & $(7,68)$ \\
Vitamina A & $(14,06)$ & $(12,63)$ & 17,72 \\
& 33,34 & 28,82 & $(29,16)$ \\
Vitamina C & $(35,42)$ & $(34,27)$ & 9,38 \\
& 19,68 & 18,95 & $(20,98)$ \\
Vitamina B6 & $(24,85)$ & $(27,49)$ & 4,29 \\
& 7,64 & 5,84 & $(11,82)$ \\
Cálcio & $(14,74)$ & $(11,10)$ & 2,62 \\
& 4,44 & 9,21 & $(3,35)$ \\
\hline
\end{tabular}

Nota: Os números entre parênteses são os desvios-padrão.

Tabela 31. Participação relativa de energia e nutrientes (selecionados) provenientes das frutas consumidas pelos escolares da rede pública de ensino de acordo com a análise sensorial. Piracicaba, 2001.

\begin{tabular}{lrrr}
\hline $\begin{array}{c}\text { Energia e Nutrientes } \\
(\%)\end{array}$ & Gostou Muito & Gostou Pouco & Não Gostou \\
\hline Energia & & & 3,71 \\
& 4,07 & 4,01 & $(4,20)$ \\
Proteínas & $(6,30)$ & $(6,32)$ & 1,42 \\
& 1,16 & 0,95 & $(2,22)$ \\
Vitamina A & $(2,56)$ & $(2,30)$ & 9,90 \\
& 6,50 & 5,01 & $(20,18)$ \\
Vitamina C & $(15,88)$ & $(13,89)$ & 29,05 \\
& 19,69 & 20,62 & $(38,64)$ \\
Vitamina B6 & $(32,97)$ & $(32,96)$ & 3,07 \\
& 2,21 & 2,19 & $(4,33)$ \\
Cálcio & $(5,67)$ & $(6,47)$ & 3,46 \\
& 1,71 & 1,61 & $(5,88)$ \\
\hline
\end{tabular}

Nota: Os números entre parênteses são os desvios-padrão. 
Considerando os dados da Tabela 30, constata-se que a participação da energia proveniente das hortaliças (4,77\%) na dieta dos escolares que declararam "gostar muito" das hortaliças minimamente processadas, é praticamente o dobro da participação observada $(2,32 \%)$ quando se considerou o grupo que alegou "não gostar". Tendência similar de superioridade foi constatada para a participação de nutrientes (proteínas, vitamina $A$, vitamina $C$ e vitamina $B_{6}$ ) na dieta do grupo que "gostou muito" dos vegetais minimamente processados.

O resultado obtido permite inferir que há uma tendência entre os alunos, que apresentaram um padrão de consumo, que contempla a maior participação de energia e nutrientes, provenientes das hortaliças, de também terem se manifestado favoravelmente, registrando ter "gostado muito" da cenoura e vagem minimamente processadas.

Analisando os resultados apresentados na Tabela 31, observa-se que a participação da energia na dieta, proveniente das frutas é ligeiramente maior para o grupo que alegou "gostar muito" dos vegetais minimamente processados.

Quando se examina os maiores valores registrados para proteínas, vitamina $A$, vitamina $C$, vitamina $B 6$ e cálcio, observa-se que os mesmos foram registrados para o grupo de alunos que afirmaram "não gostar" das hortaliças minimamente processadas.

Merece destaque, o percentual de participação de 9,90\%, observado para vitamina $A$, entre os escolares que não gostaram da cenoura e vagem (teste de análise sensorial), enquanto para o grupo que "gostou muito" dos vegetais, a contribuição das frutas foi de $6,5 \%$.

Situação similar é verificada para vitamina C, ou seja, participação de $29,05 \%$ provenientes das frutas, para os escolares que não gostaram dos vegetais, enquanto a proporção cai para $19,69 \%$ quando se considera o conjunto de alunos que gostaram muito dos vegetais minimamente processados. 
Também surpreendente são os valores verificados para o cálcio: $3,46 \%$ de contribuição das frutas, para escolares que não gostaram dos alimentos minimamente processados e apenas $1,71 \%$ de participação para a dieta daqueles alunos que registraram ter gostado dos alimentos que integraram a análise sensorial.

Complementando as análises, julgou-se pertinente incluir nesta seção as análises que envolvem a aceitabilidade das hortaliças minimamente processadas pelos escolares e a participação relativa dos macronutrientes no Valor Energético Total - VET (Tabela 32).

Tabela 32. Distribuição dos escolares de acordo com a participação relativa dos macronutrientes no Valor Energético Total - VET e aceitabilidade das hortaliças minimamente processadas (cenoura e vagem). Piracicaba, 2001.

\begin{tabular}{|c|c|c|c|c|c|c|c|c|}
\hline \multirow{2}{*}{$\begin{array}{c}\text { Participação } \\
\text { dos } \\
\text { macroutrientes } \\
\text { no VET } \\
\end{array}$} & \multirow{2}{*}{\multicolumn{2}{|c|}{ Observações }} & \multicolumn{2}{|c|}{ Gostou muito } & \multicolumn{2}{|c|}{ Aceitabilidade } & \multicolumn{2}{|c|}{ Não gostou } \\
\hline & & & $\begin{array}{c}\text { Gos } \\
n^{\circ}\end{array}$ & $\begin{array}{l}\text { muito } \\
\%\end{array}$ & $\begin{array}{c}\text { Gos } \\
n^{\circ}\end{array}$ & $\begin{array}{c}\text { pouco } \\
\%\end{array}$ & $\begin{array}{l}\text { Não } \\
\text { no}^{\circ}\end{array}$ & $\begin{array}{r}\text { ostou } \\
\%\end{array}$ \\
\hline Adequada & 76 & 36,19 & 45 & $\begin{array}{r}59,21 \\
(36,89)\end{array}$ & 20 & $\begin{array}{r}26,32 \\
(30,30)\end{array}$ & 11 & $\begin{array}{r}14,47 \\
(50,00)\end{array}$ \\
\hline Inadequada & 134 & 63,81 & 77 & $\begin{array}{r}57,46 \\
(63,11)\end{array}$ & 46 & $\begin{array}{r}34,33 \\
(69,70)\end{array}$ & 11 & $\begin{array}{r}8,21 \\
(50,00)\end{array}$ \\
\hline TOTAL & 210 & 100,00 & 122 & 100,00 & 66 & 100,00 & 22 & 100,00 \\
\hline
\end{tabular}

$\chi^{2}=2,83$, com 2 graus de liberdade, não-significativo.

$\chi^{2}(\mathrm{MH})=0,22$, com 1 grau de liberdade, não-significativo.

Nota: Os números entre parênteses são os percentuais em relação ao total observado na coluna.

Conforme pode ser observado, não houve associação entre as variáveis analisadas, captadas pelos testes de qui-quadrado comum e quiquadrado de Mantel-Haenszel. No entanto, examinando os dados da Tabela 32 é possível verificar que para o grupo de escolares que apresentou dieta adequada $(36,19 \%)$, a maioria $(59,21 \%)$ declarou que gostou muito dos alimentos minimamente processados (cenoura e vagem), enquanto $26,32 \%$ registrou "gostar pouco" e 14,47\% informou que não gostou. Também se 
revelou elevada (57,46\%), a proporção de escolares com dieta inadequada, que informaram ter gostado muito dos alimentos.

Vale salientar que ao analisar os dados relativos ao grupo de alunos que informou "não gostar" da vagem e da cenoura minimamente processadas, observa-se que $50 \%$ tiveram suas dietas classificadas como adequadas no tocante à participação dos macronutrientes no VET. Note-se também que o grupo que rejeitou os alimentos, registrando que "não gostou" é formado por apenas 22 escolares, ou seja, $10,5 \%$ do total $(n=210)$. 


\section{CONCLUSÕES}

Os resultados obtidos, tendo por base amostral, 210 escolares, com idade entre 7 a 14 anos matriculados em 6 escolas da Rede Pública de Ensino do Município de Piracicaba, revelaram que 35,2\% das meninas e 32,4\% dos meninos apresentaram sobrepeso. Foi possível, também, identificar 15,7\% de escolares obesos e inversamente, apenas 1,9\% dos integrantes da amostra, com indicativo de baixo peso.

No tocante ao consumo de energia, verificou-se que $50 \%$ dos alunos, revelou consumo, cujo teor total não alcança o valor mínimo recomendado para o grupo.

Situação nutricional desfavorável foi identificada quando se analisou o consumo dos minerais cálcio e ferro. A maioria (90\%) dos escolares consumiu quantidade média inferior a $1300 \mathrm{mg} / \mathrm{dia}$ e, apenas a metade dos integrantes da amostra, ingerem, conteúdo mínimo preconizado para o grupo.

Com relação à adequação da participação dos macronutrientes no valor energético total da dieta dos escolares, observou-se que apenas $36,19 \%$ dos alunos tiveram o consumo avaliado como adequado.

Analisando os dados relativos à proporção $(27,8 \%)$ das famílias que declarou manter o hábito de consumir hortaliças seis ou mais vezes por semana, verificou-se que o maior percentual de citações $(40,7 \%)$ foi observado, quando se considerou o grupo de mães com maior escolaridade.

Associação positiva foi verificada entre as variáveis freqüência de consumo de hortaliças e rendimento familiar per capita. 
A preferência dos escolares, para o consumo de hortaliças no âmbito do domicílio, recaiu sobre a alface (93,8\% das citações). Quando se considerou a rejeição pelos escolares, a escarola e o quiabo receberam o maior número de citações.

Os resultados da análise sensorial revelaram que $58,10 \%$ dos escolares informaram ter gostado muito das hortaliças minimamente processadas, submetidas à análise sensorial. Observou-se que dentre esses, $61 \%$ pertencem æ̀ famílias com menor renda per capita.

As análises mostram, que há diferenças quando se discrimina os escolares, de acordo com o gênero: 17,14\% das meninas afirmaram "não gostar" das hortaliças minimamente processadas e apenas, 3,81\% dos meninos registraram a mesma opinião. 
ANEXOS 
ANEXOA - Carta solicitando a listagem das escolas da rede de ensino de Piracicaba.

Piracicaba, de de 2001.

$\| m^{\circ} \mathrm{Sr}$

Diretor de Ensino

Prof. Benedito Bicheri

Prezado Professor,

Tem esta o objetivo de apresentar a Srt ${ }^{\underline{a}}$ Michele Sanches, aluna regular do Curso de Pós-Graduação em Ciência e Tecnologia de Alimentos (Nível Mestrado) do Departamento de Agroindústria, Alimentos e Nutrição, da ESALQ/USP.

A referida aluna é, também, bolsista do Conselho Nacional de Desenvolvimento Científico e Tecnológico - CNPq, e deverá desenvolver pesquisa intitulada "A Participação das Hortaliças Minimamente Processadas nas Refeições do Programa de Alimentação Escolar".

Para a fase de definição da amostra de sua pesquisa, a mestranda necessita da listagem das escolas públicas do município (discriminando as unidades estaduais e as municipais), bem como o endereço completo e o número de alunos matriculados (previsão para 2001) .

Para tanto, estamos solicitando a especial atenção de V.Sa. no sentido de analisar a possibilidade de fornecer o referido documento.

É importante registrar que serão tomadas, por nossa parte, todas as providências para que a atividade de pesquisa siga os rigorosos padrões éticos. Como tem sido o nosso procedimento rotineiro, ao concluir o trabalho da dissertação, os resultados serão disponibilizados àDiretoria de Ensino de Piracicaba.

Certos de contar com a imprescindível colaboração de V.Sa., antecipamos os nossos agradecimentos e colocamo-nos àdisposição para esclarecimentos que se façam necessários.

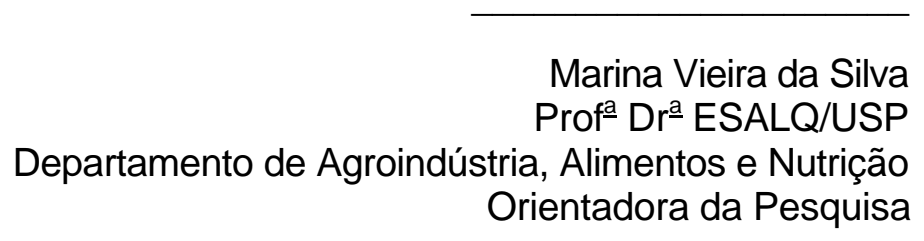

* Com cópia para o Prof. Vagner Aparecido de Nicolai Hernandez (Assistente Técnico Pedagógico). 
ANEXO B - Distribuição das escolas da rede estadual de ensino, de acordo com a região do município e número de alunos matriculados na rede estadual de ensino. Piracicaba, 2001.

\begin{tabular}{|c|c|c|c|c|}
\hline $\begin{array}{c}\text { REGIÄO/ } \\
\text { № DE ESCOLAS }\end{array}$ & ESCOLA & BAIRRO & SÉRIES & TOTAL DE ALUNOS \\
\hline $\begin{array}{c}1 \\
1 \\
1 \\
1 \\
1 \\
1 \\
1 \\
1 \\
1 \\
1 \\
1 \\
1 \\
1 \\
\text { Sub-total }=13\end{array}$ & $\begin{array}{l}\text { E.E. Prof. Affonso José Fioravante } \\
\text { E.E. Dr. Alfredo Cardoso } \\
\text { E.E. Augusto Saes } \\
\text { E.E. Prof. Benedito Ferreira da Costa } \\
\text { E.E. Prof. Elias de Mello Ayres } \\
\text { E.E. Honorato Faustino } \\
\text { E.E. Prof }{ }^{a} \text { Jaçanã A.P. Guerrini } \\
\text { E.E. Dr. Jorge Coury } \\
\text { E.E. Prof. José de M. Moraes } \\
\text { E.E. Moraes Barros } \\
\text { E.E. Dr. Prudente } \\
\text { E.E. Barão do Rio Branco } \\
\text { E.E. Sud Mennucci }\end{array}$ & $\begin{array}{l}\text { Vila Monteiro } \\
\text { Bairro Alto } \\
\text { Nova América } \\
\text { Bairro Alto } \\
\text { São Dimas } \\
\text { São Dimas } \\
\text { Independência } \\
\text { Paulista } \\
\text { São Judas } \\
\text { Centro } \\
\text { Cidade Jardim } \\
\text { Centro } \\
\text { Alto }\end{array}$ & 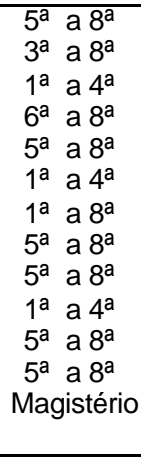 & $\begin{array}{r}643 \\
1.287 \\
855 \\
1.232 \\
2.014 \\
535 \\
977 \\
2.244 \\
1.519 \\
756 \\
939 \\
966 \\
2.222 \\
16.189\end{array}$ \\
\hline $\begin{array}{c}2 \\
2 \\
2 \\
2 \\
2 \\
2 \\
\text { Sub-total }=6 \\
\end{array}$ & $\begin{array}{l}\text { E.E. Prof. Adolpho Carvalho } \\
\text { E.E. Prof. Eduir B. Scarpari } \\
\text { E.E. João Guidotti } \\
\text { E.E. Prof }{ }^{\mathrm{a}} \text { Juracy N.M. Ferraciú } \\
\text { E.E. Prof }{ }^{\mathrm{a}} \text { Mirandolina de A. Canto } \\
\text { E.E. Pedro Moraes Cavalcanti }\end{array}$ & $\begin{array}{c}\text { Cecap } \\
\text { Jardim Alvorada } \\
\text { Morumbi } \\
\text { Noiva da Colina } \\
\text { Piracicamirim } \\
\text { Dois Córregos }\end{array}$ & 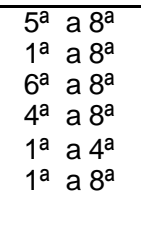 & $\begin{array}{r}1.445 \\
1.852 \\
1.097 \\
648 \\
877 \\
969 \\
6.888\end{array}$ \\
\hline $\begin{array}{c}3 \\
3 \\
3 \\
3 \\
3 \\
3 \\
3 \\
3 \\
\text { Sub-total }=8\end{array}$ & $\begin{array}{l}\text { E.E. Prof. Alcides Guidetti Zagato } \\
\text { E.E. Antônio de Mello Cotrim } \\
\text { E.E. Dr. Antônio Pinto de A. Ferraz } \\
\text { E.E. Dr. Dario Brasil } \\
\text { E.E. Dr. João Conceição } \\
\text { E.E. Com. Luciano Guidotti } \\
\text { E.E. Prof }{ }^{a} \text { Mellita L. Brasiliense } \\
\text { E.E. Prof }{ }^{a} \text { Olívia Bianco }\end{array}$ & $\begin{array}{c}\text { Jardim Esplanada } \\
\text { Paulicéia } \\
\text { Caxambu } \\
\text { Paulicéia } \\
\text { Paulista } \\
\text { Jardim Jupiá } \\
\text { Jaraguá } \\
\text { Jaraguá }\end{array}$ & 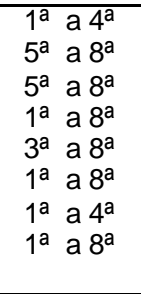 & \begin{tabular}{r|}
810 \\
1.824 \\
594 \\
1.257 \\
1.441 \\
1.139 \\
246 \\
1.667 \\
8.978 \\
\end{tabular} \\
\hline $\begin{array}{c}4 \\
4 \\
4 \\
4 \\
4 \\
4 \\
\text { Sub-total }=6\end{array}$ & $\begin{array}{l}\text { E.E. Augusto Melega } \\
\text { E.E. Prof. Francisco M. da Costa } \\
\text { E.E. Prof. Hélio Nehring } \\
\text { E.E. Prof. Jethro Vaz de Toledo } \\
\text { E.E. Dr. João Sampaio } \\
\text { E.E. Prof. Manassés F. Pereira }\end{array}$ & $\begin{array}{l}\text { Campestre } \\
\text { Novo Horizonte } \\
\text { São Jorge } \\
\text { Itapuã } \\
\text { Ibirapuera } \\
\text { Monte Líbano }\end{array}$ & 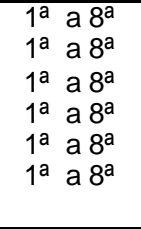 & $\begin{array}{r}350 \\
913 \\
1.018 \\
1.265 \\
1.619 \\
1.560 \\
6.725\end{array}$ \\
\hline
\end{tabular}


ANEXO B - Distribuição das escolas da rede estadual de ensino, de acordo com a região do município e número de alunos matriculados na rede estadual de ensino. Piracicaba, 2001.

\begin{tabular}{|c|c|c|c|c|}
\hline $\begin{array}{c}\text { REGIAO/ } \\
N^{2} \text { DE ESCOLAS }\end{array}$ & ESCOLA & BAIRRO & SERIES & TOTAL DE ALUNOS \\
\hline $\begin{array}{c}5 \\
5 \\
5 \\
5 \\
5 \\
5 \\
5 \\
\text { Sub-total }=7\end{array}$ & $\begin{array}{l}\text { E.E. Prof. Abigal de A. Grillo } \\
\text { E.E. Bairro Santa Rosa } \\
\text { E.E. Francisca Elisa da Silva } \\
\text { E.E. Mons. Jeronymo Gallo } \\
\text { E.E. Prof. Dr. João Chiarini } \\
\text { E.E. José Romão } \\
\text { E.E. Com. Mário Dedini }\end{array}$ & $\begin{array}{l}\text { Nhô-Quim } \\
\text { Santa Rosa } \\
\text { Jardim Monumento } \\
\text { Vila Rezende } \\
\text { Vila Fátima } \\
\text { Vila Rezende } \\
\text { Algodoal }\end{array}$ & 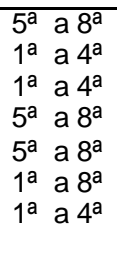 & $\begin{array}{r}1.805 \\
206 \\
676 \\
1.808 \\
729 \\
1.409 \\
574 \\
7.207\end{array}$ \\
\hline $\begin{array}{c}6 \\
6 \\
6 \\
6 \\
6 \\
\text { Sub-total }=5\end{array}$ & $\begin{array}{l}\text { E.E. Prof }{ }^{a} \text { Catharina C. Padovani } \\
\text { E.E. Prof. Carlos Sodero } \\
\text { E.E. Prof. Hélio Penteado de Castro } \\
\text { E.E. Dr. Luiz G.C. de Toledo } \\
\text { E.E. Prof }{ }^{a} \text { Maria de Lourdes S. Cosentino }\end{array}$ & $\begin{array}{l}\text { Sta. Terezinha } \\
\text { Boa Esperança } \\
\text { Parque Piracicaba } \\
\text { Vila Industrial } \\
\text { Jardim Sônia }\end{array}$ & 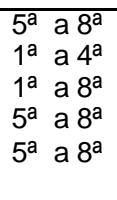 & $\begin{array}{r}2.206 \\
431 \\
1.340 \\
745 \\
1.820 \\
6.542\end{array}$ \\
\hline $\begin{array}{c}7^{*} \\
7^{\star} \\
\text { Sub-total }=2\end{array}$ & $\begin{array}{l}\text { E.E. Prof }{ }^{a} \text { Carolina Mendes Thame } \\
\text { E.E. Dr. Samuel C. Neves }\end{array}$ & $\begin{array}{l}\text { São Francisco } \\
\text { Santana }\end{array}$ & $\begin{array}{ll}1^{\mathrm{a}} & \text { a } 8^{\mathrm{a}} \\
1^{\mathrm{a}} & \text { a } 8^{\mathrm{a}}\end{array}$ & $\begin{array}{r}832 \\
232 \\
1.064\end{array}$ \\
\hline $\begin{array}{c}\text { 7/D* } \\
\text { 7/D* } \\
\text { 7/D* } \\
\text { 7/D* } \\
\text { 7/D* } \\
\text { Sub-total = 5 } \\
\end{array}$ & $\begin{array}{l}\text { E.E. Felipe Cardoso } \\
\text { E.E. Prof. João Alves de Almeida } \\
\text { E.E. Prof. José M. de Toledo } \\
\text { E.E. Paulo Luiz Valério } \\
\text { E.E. Pedro de Mello }\end{array}$ & $\begin{array}{l}\text { Anhumas } \\
\text { Tanquinho } \\
\text { Ártemis } \\
\text { Serrote } \\
\text { Tupi }\end{array}$ & 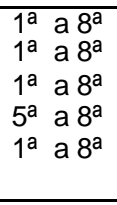 & $\begin{array}{r}297 \\
341 \\
867 \\
284 \\
640 \\
2.429 \\
\end{array}$ \\
\hline TOTAL $=53$ & & & & 56.022 \\
\hline
\end{tabular}

$7^{*}=$ Escolas Rurais Diversas.

$7 / D^{*}=$ Escolas Rurais pertencentes aos Distritos. 
ANEXO C - Carta solicitando autorização ao diretor de ensino de Piracicaba para poder realizar a pesquisas nas escolas.

Piracicaba, de de 2001.

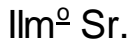

Prof. Benedito Bicheri

Diretor de Ensino de Piracicaba

Prezado Professor,

Tem esta o objetivo de apresentar a Srt ${ }^{\underline{a}}$ Michele Sanches, aluna regular do Curso de Pós-Graduação em Ciência e Tecnologia de Alimentos (nível mestrado).

Registramos, também, que a aluna é bolsista do Conselho Nacional Desenvolvimento Científico e Tecnológico - CNPq.

O CNPq aprovou a bolsa de mestrado mediante a apresentação do projeto "A Participação das Hortaliças Minimamente Processadas nas Refeições do Programa de Alimentação Escolar", que deverá ser implementado durante o período de abril de 2001 a dezembro de 2001.

O trabalho prevê o levantamento de dados em 06 escolas públicas, (E.E. Augusto Melega, E.E. Monsenhor Jeronymo Gallo, E.E. Dr. Luiz Gonzaga de Campos Toledo, E.E. Prof. José de Melo Moraes, E.E. Prof. João Guidotti, E.E. Dr. Dario Brasil) do município de Piracicaba, tendo por universo da pesquisa 210 escolares e respectivas famílias.

Para pleno êxito da pesquisa, necessitamos da especial atenção de V.S ${ }^{a}$, no sentido de registrar recomendação aos diretores das escolas para que facilitem o acesso da bolsista Michele Sanches, às unidades de ensino.

É importante, também, que apresentemos ao CNPq o registro do interesse, da Diretoria de Ensino, pelos resultados da pesquisa. Desse modo, seria muito importante dispor de um documento registrando o apoio da Diretoria de Ensino de Piracicaba.

Certos de contar com o costumeiro apoio de V.S르, antecipamos os nossos agradecimentos e colocamo-nos à disposição para esclarecimentos que se façam necessários.

Marina Vieira da Silva Prof $^{\mathrm{a}}$ Dr $^{\mathrm{a}}$ ESALQ/USP 
ANEXO D - Carta solicitando autorização às diretoras das escolas sorteadas para a realização da pesquisa.

Piracicaba, de de 2001.

$\| m^{\mathrm{a}} \mathrm{Sr}^{\mathrm{a}}$

$\operatorname{Prof}^{\mathrm{a}}-\mathrm{Dr}^{\mathrm{a}}$

Diretora da E.E.

Prezada Professora,

Tem esta o objetivo de apresentar a Srt ${ }^{\underline{a}}$ Michele Sanches, aluna regular do Curso de Pós-Graduação em Ciência e Tecnologia de Alimentos (Nível Mestrado) do Departamento de Agroindústria, Alimentos e Nutrição, da ESALQ/USP.

A referida aluna é, também, bolsista do Conselho Nacional de Desenvolvimento Científico e Tecnológico - CNPq, e vem desenvolvendo pesquisa intitulada "A Participação das Hortaliças Minimamente Processadas nas Refeições do Programa de Alimentação Escolar".

Após cuidadoso levantamento do número de escolas públicas, a sua distribuição geográfica pelos bairros da cidade e, também, o número de alunos matriculados, foi possível selecionar o número de escolas e respectivos alunos da faixa etária de 7 a 14 anos, que participarão da pesquisa.

Por meio de sorteio, a escola dirigida por V.Sa. foi selecionada para compor a amostra da pesquisa implementada pela referida aluna.

Desse modo, estamos solicitando a especial atenção de V.Sa. no sentido de analisar a possibilidade de autorizar o levantamento de dados junto aos alunos.

Entrevistaremos cerca de 35 alunos do período da tarde e faremos uma análise sensorial juntamente com eles

As melhores datas e horários deverão ser decididos por V.Sa., juntamente com a Srt ${ }^{\underline{a}}$ Michele.

É importante registrar que serão tomadas por nossa parte, todas as providências para que a atividade de pesquisa não atrapalhe as inúmeras rotinas da escola.

Vale registrar que deverão ser registradas as medidas antropométricas (peso e altura) dos alunos e, também, realizar entrevista visando conhecer, principalmente, os hábitos alimentares dos mesmos.

Complementa o presente documento, cópia da carta do Prof. Benedito Bicheri, cuja manifestação registra a aquiescência da Diretoria de Ensino de Piracicaba, para o desenvolvimento da pesquisa.

Certos de contar com a imprescindível colaboração de V.Sa., antecipamos os nossos agradecimentos e colocamo-nos à disposição para esclarecimentos que se façam necessários.

Marina Vieira da Silva Prof $^{\mathrm{a}}$ Dr ${ }^{\mathrm{a}} \mathrm{ESALQ} / \mathrm{USP}$

Departamento de Agroindústria, Alimentos e Nutrição Orientadora da Pesquisa 
ANEXO E - Planilha das medidas antropométricas.

\section{CNPq/ESALQ/USP}

ESCOLA:

ENDEREÇO:

Responsável pela coleta de dados:

Nome, assinatura e data

\begin{tabular}{|l|l|l|l|l|l|l|l|l|}
\hline Ordem & Nome completo & $\begin{array}{c}\text { Série que } \\
\text { estuda }\end{array}$ & Sexo & $\begin{array}{c}\text { Data de } \\
\text { nascimento }\end{array}$ & $\begin{array}{c}\text { Data de } \\
\text { observação }\end{array}$ & $\begin{array}{c}\text { Peso } \\
(\mathrm{Kg})\end{array}$ & $\begin{array}{c}\text { Altura } \\
(\mathrm{cm})\end{array}$ & $\begin{array}{c}\text { Informações } \\
\text { adicionais }\end{array}$ \\
\hline & & & & & & & & \\
\hline \\
\hline
\end{tabular}


ANEXO F - Registro do consumo dos alimentos (do dia anterior).

Nome do Aluno

Escola:

Série que freqüenta:

\begin{tabular}{|c|c|c|c|}
\hline Refeição & $\begin{array}{c}\text { Horário e local da } \\
\text { refeição }\end{array}$ & Alimentos já preparados & $\begin{array}{c}\text { Quantidade de alimentos } \\
\text { (já preparados) que foi } \\
\text { servida à criança } \\
\text { (medidas caseiras) }\end{array}$ \\
\hline Café da manhã & & & \\
\hline $\begin{array}{c}\text { Lanche ou Merenda } \\
\text { da manhã }\end{array}$ & & & \\
\hline Almoço & & & \\
\hline Lanche ou Merenda \\
da tarde*
\end{tabular}

- Informar se a refeição é a merenda oferecida na escola.

Data do Preenchimento: 1

Responsável pelo preenchimento: 
ANEXO G - Medidas de Utensílios Caseiros
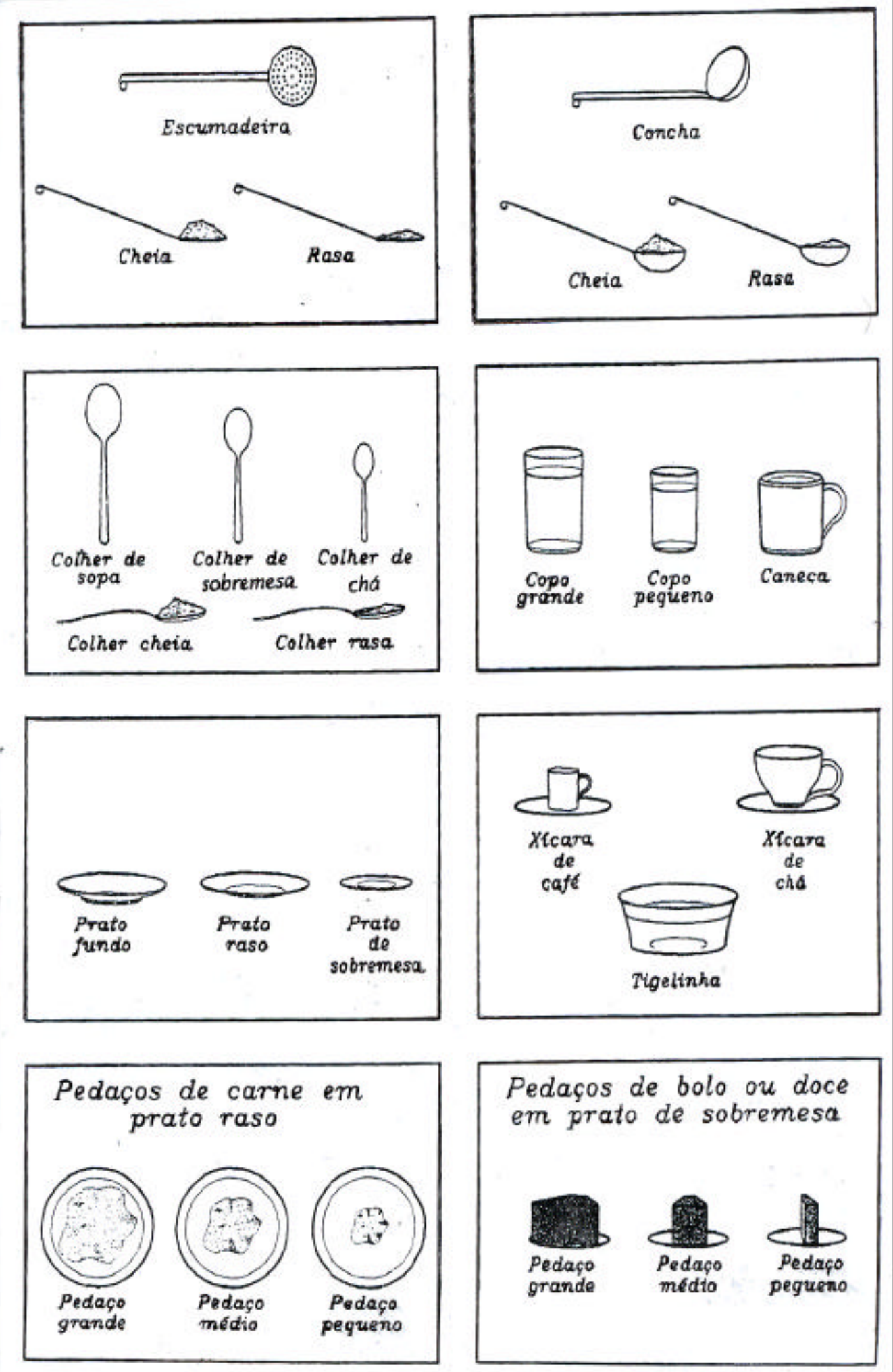

Pedaços de bolo ou doce em prato de sobremesa

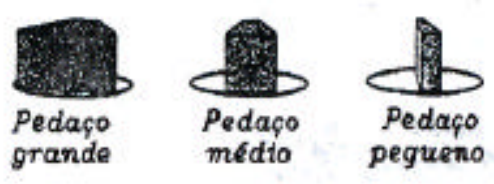


ANEXO H - Questionário dos alunos.

CNPq / ESALQ / USP

Pesquisa: "A Participação das Hortaliças Minimamente Processadas nas Refeições do Programa de Alimentação Escolar"

1-Nome da Escola:

2- Nome do Aluno: Série que freqüenta:

2.1- Sexo:

( )Masculino

( ) Feminino

3- Nesta Escola a merenda é servida:

( ) 1 vez por semana

( ) 2 vezes por semana

( ) 3 vezes por semana

( ) 4 vezes por semana

( ) todos os dias

( ) não é servida merenda nesta escola

( ) não sei, porque não observo

4- Você costuma comer a merenda da escola?

( ) Sim

( ) Não

Se você respondeu NÃO para a questão anterior passe para a questão 6. 5- Você falou que come a merenda da escola, informe quantas vezes isso ocorre no período de uma semana:

( ) 1 dia por semana

( ) 2 dias por semana

( ) 4 dias por semana

( ) 3 dias por semana

( ) todos os dias 
6- Caso você não tenha o costume de comer a merenda da escola, marque a(s) razão (ões):

Traz lanche de casa

Tem nojo

( ) Sim ( )Não

Compra lanche na cantina

( ) Sim

( )Não

Prefere brincar durante o intervalo

( ) Sim

( )Não

Não tem vontade ou fome

( ) Sim

( )Não

Compra alimentos de vendedores ambulantes perto da escola

() Sim

( )Não

Não gosta de comer entre as refeições

( ) Sim

( )Não

Não dá tempo

( ) Sim

)Não

( ) Sim

( )Não

( )Outro(s) motivo(s). Qual (is)?

7- Cite as 5 verduras / hortaliças que você mais gosta de comer quando você está na sua casa (não considerando a merenda escolar):

8- A sua mãe ou pai ou até outro parente, costuma comprar verduras para serem consumidas, em casa, pela sua família:

( ) Sim

( ) Não

( ) Não sabe

9- Qual(is) a(s) forma(s) que você prefere que as verduras (que você citou na questão anterior) sejam preparadas?

10- Na merenda da sua escola é (são) servida(s) verdura(s)?

( ) Sim ( ) Não Não sabe 
11- Considerando as verduras que são servidas na escola cite as que você mais gosta:

12- Você só come o que gosta na merenda da escola?

( ) Sim ( )Não ( )Não sabe

13- Costuma comprar alimentos na cantina da escola?

( ) A escola não tem cantina

( ) Sim

( ) Não

14- Você costuma assistir televisão?

( ) $\operatorname{Sim}$ ( ) Não

15-Como você falou que assiste televisão, fale quanto tempo por dia você passa assistindo à TV?

horas/dia. Desse total de horas, informe no espaço a seguir, o período de:

horas durante o período da manhã horas durante o período da tarde horas a partir das $18 \mathrm{hs}$ (noite)

16- Quanto tempo (horas ou minutos) você demora para:

Tomar café da manhã:

Almoçar:

Comer a merenda (Se você come merenda):

Jantar:

Lanche

Outros: 
17- Escreva a seguir se você já ouviu falar ou leu alguma coisa sobre os alimentos apresentados abaixo:

Em caso afirmativo (SIM) diga onde você ouviu falar (ou leu) sobre esses alimentos

Alimentos transgênicos

Alimentos orgânicos

Alimentos minimamente processados

Alimentos funcionais

Alimentos "diet" e "light"

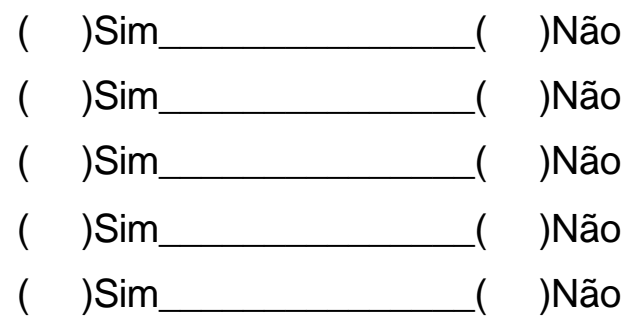

18- Você acredita que ao consumir alguns dos alimentos citados na questão anterior, a sua saúde será prejudicada, contribuindo para que você fique doente? ( )Não.

( ) Sim. Fale por quê?

19- Na sua opinião a alime ntação de meninos e meninas deve ser diferente?

( ) Sim. Por quê?

( )Não. Por quê?

20- Na sua opinião, quando você consome o alimento, você leva em consideração:

Necessidade física

Participação de um ritual com a família e/ ou grupo de amigos

( ) Sim

( )Não

O sabor dos alimentos

( ) Sim

( )Não

A rapidez que poderá consumi-los

( ) Sim

( )Não

( ) Sim

( )Não

21- Na tabela na folha seguinte, marque com um $(X)$ a freqüência que você consome os alimentos, apresentados a seguir (assinale apenas um " $X$ " por alimento) 


\begin{tabular}{|c|c|c|c|c|c|c|c|c|c|c|}
\hline Alimento & $\begin{array}{l}\text { Mais de } \\
1 \times \text { por dia }\end{array}$ & 1x por dia & $\begin{array}{l}5-6 \times \text { por } \\
\text { semana }\end{array}$ & $\begin{array}{l}3-4 \times \text { por } \\
\text { semana }\end{array}$ & $\begin{array}{l}2 \times \text { por } \\
\text { semana }\end{array}$ & $\begin{array}{c}\text { 1xpor } \\
\text { semana }\end{array}$ & $\begin{array}{c}2-3 \times \text { por } \\
\text { mês }\end{array}$ & $\begin{array}{l}1 \times \text { por } \\
\text { mês }\end{array}$ & $\begin{array}{l}\text { Menos de } \\
1 \times \text { por mês }\end{array}$ & Nunca \\
\hline \multicolumn{11}{|l|}{ Arroz } \\
\hline \multicolumn{11}{|c|}{ Macarrão } \\
\hline \multicolumn{11}{|c|}{ Massas (Ex: lasanha, nhoque etc) } \\
\hline \multicolumn{11}{|c|}{ Pão } \\
\hline \multicolumn{11}{|l|}{ Feijão } \\
\hline \multicolumn{11}{|l|}{ Ovos } \\
\hline \multicolumn{11}{|l|}{ Carne de boi/vaca } \\
\hline \multicolumn{11}{|l|}{ Carne de porco } \\
\hline \multicolumn{11}{|l|}{ Carne de frango } \\
\hline \multicolumn{11}{|c|}{ Peixe/Sardinha } \\
\hline \multicolumn{11}{|c|}{ Vísceras (fígado, língua, rim etc) } \\
\hline \multicolumn{11}{|c|}{ Lingüiça } \\
\hline \multirow{2}{*}{\multicolumn{11}{|c|}{ Salsicha }} \\
\hline & & & & & & & & & & Mortadela \\
\hline \multicolumn{11}{|l|}{ Salame } \\
\hline \multicolumn{11}{|l|}{ Presunto } \\
\hline \multicolumn{11}{|l|}{ Leite } \\
\hline \multicolumn{11}{|l|}{ Queijo } \\
\hline \multicolumn{11}{|l|}{ Requeijão } \\
\hline \multicolumn{11}{|l|}{ logurtes (Danone) } \\
\hline \multirow{2}{*}{\multicolumn{11}{|c|}{$\begin{array}{l}\text { Vitamina de frutas } \\
\text { Margarina }\end{array}$}} \\
\hline & & & & & & & & & & \\
\hline \multicolumn{11}{|l|}{$\begin{array}{l}\text { Manteiga } \\
\text { Mag }\end{array}$} \\
\hline \multicolumn{11}{|l|}{ Maionese } \\
\hline \multicolumn{11}{|l|}{ Catchup } \\
\hline \multicolumn{11}{|l|}{ Mostarda } \\
\hline \multicolumn{11}{|l|}{$\begin{array}{l}\text { Achocolatados } \\
\text { (Ex: Toddy, Nescau) }\end{array}$} \\
\hline \multicolumn{11}{|l|}{ Café } \\
\hline Biscoito"água e sal" & & & & & & & & & & \\
\hline Biscoito recheado & & & & & & & & & & \\
\hline Cereais matinais (Sucrilhos) & & & & & & & & & & \\
\hline Bolo & & & & & & & & & & \\
\hline
\end{tabular}




\begin{tabular}{|c|c|c|c|c|c|c|c|c|c|c|}
\hline Alimento & $\begin{array}{l}\text { Mais de } \\
1 \times \text { por dia }\end{array}$ & $1 \times$ por dia & $\begin{array}{l}5-6 \times \text { por } \\
\text { semana }\end{array}$ & $\begin{array}{l}3-4 \times \text { por } \\
\text { semana }\end{array}$ & $\begin{array}{l}2 \times \text { por } \\
\text { semana }\end{array}$ & $\begin{array}{l}1 \times \text { por } \\
\text { semana }\end{array}$ & $\begin{array}{l}2-3 \times \text { por } \\
\text { mês }\end{array}$ & $\begin{array}{l}1 \times \text { por } \\
\text { mês }\end{array}$ & $\begin{array}{l}\text { Menos de } \\
1 \times \text { por mês }\end{array}$ & Nunca \\
\hline \multicolumn{11}{|l|}{ Verduras (Ex: alface, couve) } \\
\hline \multirow{2}{*}{\multicolumn{11}{|c|}{ Legumes (Ex: cenoura etc) }} \\
\hline Sopa & & & & & & & & & & \\
\hline \multicolumn{11}{|l|}{ Frutas } \\
\hline \multirow{2}{*}{\multicolumn{11}{|c|}{$\begin{array}{l}\text { Sucos de frutas } \\
\text { Refrigerantes }\end{array}$}} \\
\hline & & & & & & & & & & \\
\hline \multicolumn{11}{|l|}{$\begin{array}{l}\text { Doces caseiros } \\
\text { (Ex: doce de abóbora) }\end{array}$} \\
\hline \multicolumn{11}{|l|}{$\begin{array}{l}\text { Doces industrializados } \\
\text { (Ex: paçoca) }\end{array}$} \\
\hline \multicolumn{11}{|l|}{ Gelatina } \\
\hline \multicolumn{11}{|l|}{ Chocolates e Bombons } \\
\hline \multicolumn{11}{|l|}{ Sorvetes } \\
\hline \multicolumn{11}{|l|}{ Lanches e sanduíches } \\
\hline \multicolumn{11}{|l|}{ Salgadinhos “Chips” } \\
\hline \multicolumn{11}{|l|}{ Pipoca } \\
\hline \multicolumn{11}{|l|}{ Salgados (Ex: coxinha, esfiha etc) } \\
\hline \multirow{2}{*}{\multicolumn{11}{|c|}{ Batata frita }} \\
\hline & & & & & & & & & & \\
\hline \multicolumn{7}{|l|}{ Cachorro-quente } & & & & \\
\hline \multicolumn{11}{|l|}{ Pastel } \\
\hline Outros. Quais? & & & & & & & & & & \\
\hline 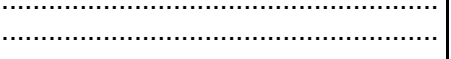 & & & & & & & & & & \\
\hline
\end{tabular}


ANEXO I - Identificação da família e das condições de vida do escolar.

CNPq / ESALQ / USP

Pesquisa: "A Participação das Hortaliças Minimamente Processadas nas Refeições do Programa de Alimentação Escolar"

\section{QUESTIONÁRIO (Pais ou Responsáveis)}

1- Escola:

2- Nome do Aluno:

Senhores pais, por favor, confiram se o nome de seu (sua) filho (a) está escrito corretamente.

2.1- Série que freqüenta:

2.2- Sexo: $\quad(\quad)$ Masculino $\quad(\quad)$ Feminino

2.3-Senhores pais, por favor, preencha, o dia, mês e ano de nascimento de seu (sua) filho (a). Data de Nascimento:

$\overline{\text { (Dia) }}^{\prime} \overline{\text { (Mês) }}^{\prime}{ }_{\text {(Ano) }}$

3- Informe o número total de pessoas (somar todos os adultos, as crianças, bebês e jovens) que vivem na sua casa:

4- A seguir, escreva:

- A mãe ou madrasta estudou durante quantos anos?

( ) nunca estudou

- O pai ou padrasto estudou durante quantos anos?

( ) nunca estudou

5- A mãe da criança trabalha fora de casa:

( ) Sim ( ) Não

( ) Já trabalhou, mas no momento está desempregada. 
6- Considere todas as pessoas da família que trabalham e receberam salário (ou pensão, ou aluguel) e ajudaram nas despesas da casa no último mês e responda: Depois de somar todos os valores o resultado é $R \$$

7- Informe, o valor em reais que o senhor(a) gastou no último mês, para comprar todos os alimentos para a sua família: $R \$$

8- $O$ (a) seu (sua) filho (a) já freqüentou a creche antes dos 6 anos de idade? ( ) Sim ( )Não

Caso o(a) senhor(a) tenha respondido que sim, preencha os espaços abaixo com os dados do (da) seu (sua) filho (a):

Meu filho entrou na creche quando tinha meses e saiu com meses.

9- Marque a seguir quem prepara as refeições para seu filho, durante a semana: Mãe

Pai

Própria criança

Empregada

Avó

Compra pronto

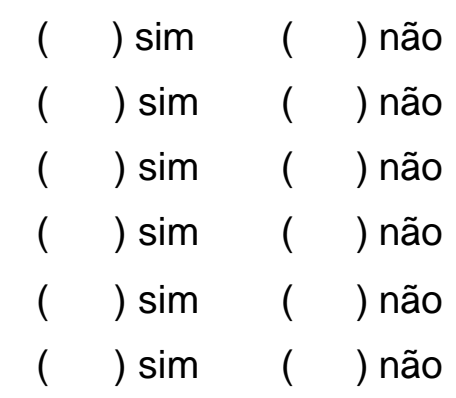

Outro. Quem?

10- Escreva, nos espaços abaixo alguns recursos que o (a) senhor(a) considera que poderiam facilitar o preparo das refeições em casa e se fosse possível, utilizaria para ter menos trabalho na cozinha:

11- O seu filho costuma comer fora de casa? (Não considere a merenda que ele recebe na escola)

( ) Sim

（） Não

( ) Não sabe 
12- Se o(a) senhor(a) respondeu que seu filho costuma consumir alimentos fora de casa, marque o número de vezes:

( ) Uma vez por semana

( ) Duas a três vezes por semana

( ) Quatro vezes por semana

( ) Todos os dias

13- Em caso afirmativo, marque o(s) local(is) onde seu filho costuma consumir alimentos ou refeições:

Lanchonetes

Bares

Ambulantes (carrinhos que vendem comida na rua)

Casa de parentes

Casa de amigos / vizinhos

$\begin{array}{lll}(\quad) \operatorname{sim} & ( & \text { )não } \\ (\quad) \operatorname{sim} & ( & \text { não } \\ (\quad) \operatorname{sim} & ( & \text { não } \\ (\quad) \operatorname{sim} & (\quad) \text { não } \\ (\quad) \operatorname{sim} & (\quad) \text { não }\end{array}$

14- Marque as refeições que seu filho faz em casa:

Café da manhã

Merenda ou lanche da manhã

Almoço

Merenda ou lanche da tarde

Jantar

Lanche Noturno

\begin{tabular}{|c|c|}
\hline ) $\operatorname{sim}$ & 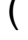 \\
\hline ) $\operatorname{sim}$ & \\
\hline ) $\operatorname{sim}$ & 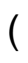 \\
\hline ) $\operatorname{sim}$ & \\
\hline ) $\operatorname{sim}$ & \\
\hline ) $\operatorname{sim}$ & \\
\hline
\end{tabular}

15- Por favor, escreva o que o (a) senhor (a) sabe sobre as verduras, destacando o papel delas no organismo dos seres humanos:

( ) não sei informar. 
16- Na sua casa as verduras são consumidas:

( ) 1 vez por semana

( ) 2 vezes por semana

( ) 3 vezes por semana

( ) 4 vezes por semana

( ) 5 vezes por semana

( ) Mais de 5 vezes por semana (situação que envolve a presença de verdura em mais de uma refeição do dia).

( ) Não consumimos verduras.

17- Escreva qual (is) é (são) as verduras que de uma forma geral, o pessoal da sua família mais gosta e consome:

( ) a família não aprecia nenhuma verdura e portanto não consome.

18- Informe, considerando a sua opinião, que alimentos a merenda (oferecida na escola) deveria conter, para que seu filho cresça e se desenvolva adequadamente:

19- O (a) Senhor (a) acredita que, caso os alimentos citados (anteriormente) fossem servidos na escola, seu filho os consumiria?

( ) Sim. Por quê?

) Não. Por quê?

( ) Não sabe dizer. 
20- Marque a seguir, uma ou mais das "situações" que contribuiriam para que a sua família passasse a consumir mais verduras:

Ser mais barata

Ser vendida congelada

Verdureiro entregar em casa

Estarem limpas e prontas para serem consumidas ( ) Sim ( ) Não

( ) Sim ( ) Não

( ) Sim ( ) Não

( ) Sim ( ) Não

( ) não sabe

21- Marque a seguir se o senhor(a) já ouviu falar ou leu alguma coisa sobre os alimentos citados abaixo. Em caso afirmativo, por favor, escreva a fonte de informação:

Alimentos transgênicos

Alimentos orgânicos

Alimentos minimamente processados

Alimentos funcionais

Alimentos "diet" e "light"

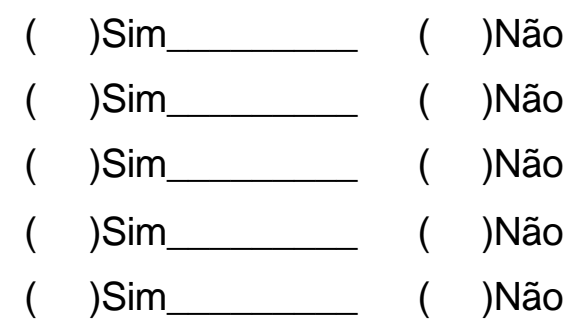

22- $O$ (a) Sr. (a) acredita que ao consumir alguns dos alimentos acima citados, a sua saúde será prejudicada, contribuindo para que o (a) Sr. (a) fique doente?

( ) Não.

( ) Sim. Fale por quê? 
ANEXO J-Carta dirigida aos pais ou responsáveis onde se registrou os propósitos da pesquisa

Piracicaba, de de 2001.

Senhores Pais,

A Escola Superior de Agricultura "Luiz de Queiroz" - ESALQ/USP com a participação de aluna do curso de pós-graduação está desenvolvendo a pesquisa "A Participação das Hortaliças Minimamente Processadas nas Refeições do Programa de Alimentação Escolar".

No mês de abril, maio e junho a pesquisadora responsável pela obtenção dos dados estará visitando a escola onde o seu filho estuda, para obter as informações necessárias para a pesquisa.

Para que seja possível alcançar os objetivos, pedimos a valiosa colaboração dos senhores no sentido de preencher e devolver este questionário no prazo máximo de 02 (dois) dias.

É importante registrar que as análises que serão elaboradas poderão contribuir, de forma significativa, para que possamos desenvolver inúmeros trabalhos educativos sobre o tema alimentação e nutrição, dirigidos para os escolares de Piracicaba.

Os dados obtidos serão analisados, atendendo todas as exigências éticas, isto é, nomes, endereços e demais informações serão mantidas em sigilo.

Esperamos contar com a participação de todos.

Muito obrigada pela atenção.

Prof ${ }^{-a}$ Dr- Marina Vieira da Silva ESALQ/USP - Responsável pela Pesquisa 
ANEXO K - Cardápio do programa de merenda escolar da rede de ensino de Piracicaba, 2001.

\begin{tabular}{|c|c|c|c|c|c|}
\hline \multicolumn{6}{|c|}{ Cardápio para escolas estaduais e municipais - 2001} \\
\hline & Segunda-feira & Terça-feira & Quarta-feira & Quinta-feira & Sexta-feira \\
\hline Entrada & $\begin{array}{l}\text { Leite c/ chocolate } \\
\text { Pão c/ margarina }\end{array}$ & $\begin{array}{l}\text { Leite c/ chocolate } \\
\text { Biscoito salgado }\end{array}$ & $\begin{array}{l}\text { Leite } \mathrm{c} / \text { chocolate } \\
\text { Pão c/ margarina }\end{array}$ & $\begin{array}{l}\text { Leite c/ chocolate } \\
\text { Biscoito doce }\end{array}$ & $\begin{array}{l}\text { Leite c/ chocolate } \\
\text { Pão c/ margarina }\end{array}$ \\
\hline $\begin{array}{l}\text { Primeira } \\
\text { Semana }\end{array}$ & $\begin{array}{l}\text { Sopa de macarrão } \\
\text { c/ carne e legumes }\end{array}$ & $\begin{array}{c}\text { Arroz } \\
\text { Ovos mexidos com } \\
\text { legumes }\end{array}$ & $\begin{array}{l}\text { Risoto } \\
\text { de } \\
\text { Frango }\end{array}$ & $\begin{array}{c}\text { Arroz e feijão } \\
\text { Cação ao molho }\end{array}$ & $\begin{array}{c}\text { Sopa de feijão c/ } \\
\text { macarrão, carne e } \\
\text { legumes }\end{array}$ \\
\hline $\begin{array}{l}\text { Segunda } \\
\text { Semana }\end{array}$ & $\begin{array}{l}\text { Sopa de macarrão } \\
\text { c/ carne e legumes }\end{array}$ & $\begin{array}{c}\text { Arroz e feijão } \\
\text { Ovos mexidos c/ } \\
\text { legumes }\end{array}$ & $\begin{array}{l}\text { Cuscuz de frango } \\
\text { c/ legumes e ovos }\end{array}$ & $\begin{array}{l}\text { Macarronada c/ } \\
\text { carne }\end{array}$ & $\begin{array}{c}\text { Sopa de feijão c/ } \\
\text { macarrão, carne e } \\
\text { legumes }\end{array}$ \\
\hline $\begin{array}{l}\text { Terceira } \\
\text { Semana }\end{array}$ & $\begin{array}{l}\text { Sopa de macarrão } \\
\text { c/ carne e legumes }\end{array}$ & $\begin{array}{c}\text { Arroz } \\
\text { Ovos mexidos com } \\
\text { legumes }\end{array}$ & $\begin{array}{c}\text { Arroz e feijão } \\
\text { Frango ao molho }\end{array}$ & $\begin{array}{l}\text { Macarronada c/ } \\
\text { carne moída }\end{array}$ & $\begin{array}{l}\text { Sopa de feijão c/ } \\
\text { macarrão, carne e } \\
\text { legumes }\end{array}$ \\
\hline $\begin{array}{l}\text { Quarta } \\
\text { Semana }\end{array}$ & $\begin{array}{l}\text { Sopa de macarrão } \\
\text { c/ carne e legumes }\end{array}$ & $\begin{array}{c}\text { Arroz } \\
\text { Ovos mexidos c/ } \\
\text { legumes }\end{array}$ & $\begin{array}{l}\text { Polenta } \\
\text { com } \\
\text { frango }\end{array}$ & $\begin{array}{c}\text { Arroz e feijão } \\
\text { Carne c/ legumes }\end{array}$ & $\begin{array}{l}\text { Sopa de feijão c/ } \\
\text { macarrão, carne e } \\
\text { legumes }\end{array}$ \\
\hline
\end{tabular}

* Quando houver quinta semana deve-se seguir o mesmo cardápio da quarta semana.

Fonte: Divisão de Alimentação e Nutrição. Piracicaba, 2001. 
ANEXO L - Escala hedônica utilizada na avaliação da percepção sensorial das hortaliças minimamente processadas.

NOME:

SÉRIE:

ESCOLA: DATA:
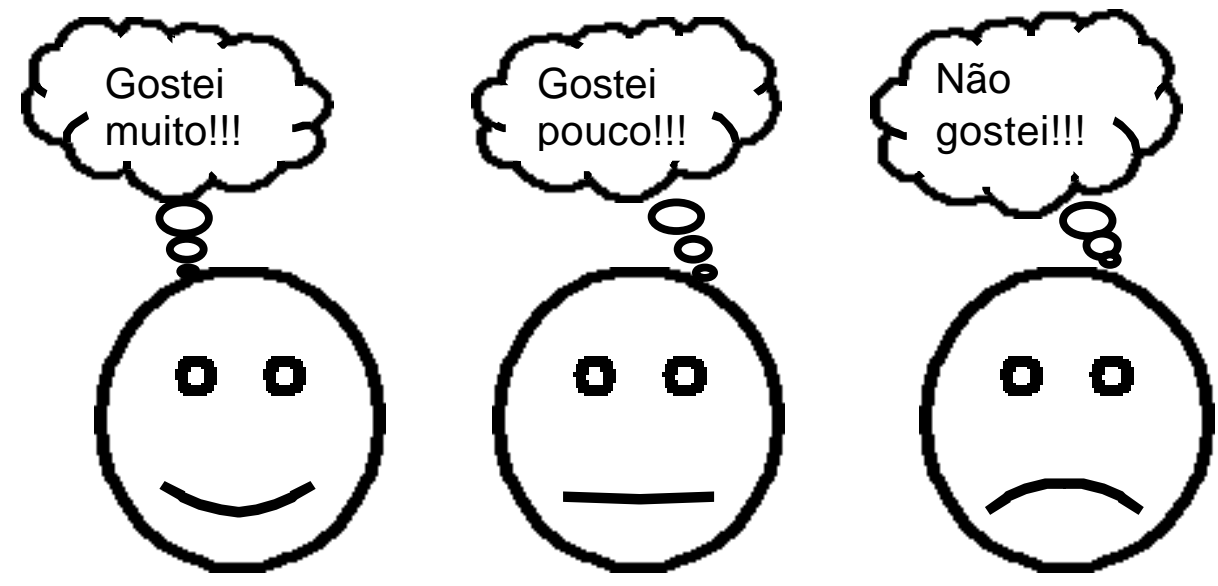

Fonte: Oliveira, 1997. 


\section{REFERÊNCIAS BIBLIOGRÁFICAS}

ALBANO, R.D. Estado nutricional e consumo alimentar de adolescentes. São Paulo, 2000. 70p. Dissertação (Mestrado) - Faculdade de Saúde Pública, Universidade de São Paulo.

ALMEIDA, T.C.A. Análise sensorial: efeitos da memória. Campinas, 1996. 121p. Tese (Doutorado) - Faculdade de Engenharia de Alimentos, Universidade Estadual de Campinas.

ALMEIDA, L.C.M.; NAVES, M.M.V. Biodisponibilidade de ferro em alimentos e refeições: aspectos atuais e recomendações alimentares. Pediatria Moderna, v.38, n.6, p.272-278, jun. 2002.

ANDERSEN, L.F.; NES, M.; SANSTAD, B. et al. Dietary intake among norwegian adolescents. European Journal of Clinical Nutrition, v.49, n.8, p.555-564, 1995.

ANGELIS, R.C. Fome oculta: impacto para a população do Brasil. São Paulo: Atheneu, 1999. 236p. 
ANGELIS, R.C. Consumo de frutas e verduras e redução de riscos de doenças cardiovasculares. In: ANGELIS, R.C. Importância de alimentos vegetais na proteção da saúde: fisiologia da nutrição protetora e preventiva de enfermidades degenerativas. São Paulo: Atheneu, 2001a. cap.13, p.99104: Consumo de frutas e verduras e redução de riscos de doenças cardiovasculares.

ANGELIS, R.C. Importância de incluir vegetais na alimentação humana. In: ANGELIS, R.C. Importância de alimentos vegetais na proteção da saúde: fisiologia da nutrição protetora e preventiva de enfermidades degenerativas. São Paulo: Atheneu, 2001b. cap.7, p.51-54: Importância de incluir vegetais na alimentação humana.

BITTENCOURT, M.T.; VANETTI, M.C.D.; PUSCHMANN, R. et al. Atividade microbiana em couve minimamente processada. In: ENCONTRO NACIONAL SOBRE PROCESSAMENTO MÍNIMO DE FRUTAS E HORTALIÇAS, 2., Viçosa, 2000. Resumos. Viçosa: UFV, 2000a. p.42.

BITTENCOURT, M.T.; VANETTI, M.C.D.; PUSCHMANN, R. et al. Cinética de crescimento de psicrotróficos isolados de couve minimamente processada. In: ENCONTRO NACIONAL SOBRE PROCESSAMENTO MÍNIMO DE FRUTAS E HORTALIÇAS, 2., Viçosa, 2000. Resumos. Viçosa: UFV, 2000b. p.43.

BORGUINI, R.G. Tomate (Lycopersicum esculetun Mill) orgânico: o conteúdo nutricional e a opinião do consumidor. Piracicaba, 2002. 110p. Dissertação (Mestrado) - Escola Superior de Agricultura "Luiz de Queiroz", Universidade de São Paulo. 
BRANDÃO, T.M. Avaliação da aceitação e preferências de cardápios do Programa de Merenda Escolar em escolas municipais de ensino fundamental da cidade de Campinas. Campinas, 2000. 91p. Dissertação (Mestrado) - Faculdade de Engenharia de Alimentos, Universidade Estadual de Campinas.

BRASIL. Ministério da Educação e do Desporto. Instituto Nacional de Estudos e Pesquisas Educacionais. Avaliação da descentralização de recursos do FNDE e da merenda escolar: síntese dos resultados. Campinas: UNICAMP, Núcleo de Estudos de Políticas Públicas, dez. 1997. p.12-23.

BRASIL. Fundo Nacional de Desenvolvimento da Educação. Programa Nacional de Alimentação Escolar. http://www.fnde.gov.br (24 set. 2002)

BRICARELLO, L.P.; GOULART, R.M.M. O papel das vitaminas em lactentes e crianças. Pediatria Moderna, v.35, n.10, p.797-807, out. 1999.

CAROBA, D.C.R. A escola e o consumo alimentar de adolescentes matriculados na rede pública de ensino. Piracicaba, 2002. 162p. Dissertação (Mestrado) - Escola Superior de Agricultura "Luiz de Queiroz", Universidade de São Paulo.

CARVALHO, C.M.R.G.; NOGUEIRA, A.M.T.; TELES, J.B.M. et al. Consumo alimentar de adolescentes matriculados em um colégio particular de Teresina, Piauí, Brasil. Revista de Nutrição, v.14, n.2, p.85-93, maio/ago. 2001.

CHAVES, J.B.P. Análise sensorial: histórico e desenvolvimento. Viçosa: UFV, 1993. 31p. 
CHITARRA, M.I.F. Processamento mínimo de frutos e hortaliças. Viçosa: CPT, 1998. 88p.

CINTRA, I.P.; HEYDE, M.E.D. von der; SCHIMITZ, B.A.S. et al. Métodos de inquéritos dietéticos. Cadernos de Nutrição, v.13, p.11-23, 1997.

COSTA, E.Q.; RIBEIRO, V.M.M.; RIBEIRO, E.C.O. Programa de alimentação escolar: espaço de aprendizagem e produção de conhecimento. Revista de Nutrição, v.14, n.3, p.225-229, set./dez. 2001.

COSTELL, E.; DURAN, L. El analise sensorial en el controle de calidade de los alimentos. Revista Agroquímica y Tecnología de Alimentos, v.21, n.1, p.1-10, 1981.

DEAN, A.G.; ARNER, T.G.; SANGAM, S. et al. Epi Info 2000: database and statistics program for public health professionals for use on Windows 95, 98, NT and 2000 computers (software). Atlanta: Centers for Disease Control and Prevention, 2000.

DOMENE, S.M.A.; VÍTOLO, M.R. Consumo de vegetais no Brasil. In: ANGELIS, R.C. Importância de alimentos vegetais na proteção da saúde: fisiologia da nutrição protetora e preventiva de enfermidades degenerativas. São Paulo: Atheneu, 2001. cap.20, p.119-128: Consumo de vegetais no Brasil.

DOYLE, E.; FELDMAN, R.H.L. Factors affecting nutrition behavior among middle-class adolescents in urban area of northern region of Brazil. Revista de Saúde Pública, v.31, n.4, p.342-350, ago. 1997. 
FERREIRA, M.A. Um mercado fértil para o Brasil. Frutas \& Legumes, v.1, p.8-11, mar./abr. 2000.

FISBERG, M. Obesidade na infância e adolescência. São Paulo: Fundação BYK, 1995. 157p.

FISBERG, M.; BANDEIRA, C.R.S.; BONILHA, E.A. et al. Hábitos alimentares na adolescência. Pediatria Moderna, v.36, n.11, p.724-734, nov. 2000.

FNP CONSULTORIA \& COMÉRCIO. AGRIANUAL 99: anuário da agricultura brasileira. São Paulo, 1999. p.14-22: Comercialização.

FNP CONSULTORIA \& COMÉRCIO. AGRIANUAL 2001: anuário da agricultura brasileira. São Paulo, 2001. p.22-25: Fraca presença de frutas brasileiras no exterior.

FONSECA, V.M.; SICHIERI, R.; VEIGA, G.V. Fatores associados à obesidade em adolescentes. Revista de Saúde Pública, v.32, n.6, p.541-549, dez. 1998.

FORNÉS, N.S.; MARTINS, I.S.; HERNAN, M. et al. Food frequency consumption and lipoproteins serum evels in the population of urban area, Brazil. Revista de Saúde Pública, v.34, n.4, p.380-387, ago. 2000.

FRUTUOSO, M.F.P. Prevalência de sobrepeso e obesidade em adolescentes de um centro de juventude do município de São Paulo. São Paulo, 2000. 87p. Dissertação (Mestrado) - Faculdade de Saúde Pública, Universidade de São Paulo. 
GALEAZZI, M.A.M.; DOMENE, S.M.A.; SICHIERI, R. Estudo multicêntrico sobre consumo alimentar. Cadernos de Debate, v.7, p.11-62, v.esp. 1997.

GAMBARDELLA, A.M.D. Adolescentes, estudantes de período noturno: como se alimentam e gastam suas energias. São Paulo, 1996. 81p. Tese (Doutorado) - Faculdade de Saúde Pública, Universidade de São Paulo.

GAMBARDELLA, A.M.D.; FRUTUOSO, M.F.P.; FRANCHI, C. Prática alimentar de adolescentes. Revista de Nutrição, v.12, n.1, p.55-63, jan./abr. 1999.

GIGANTE, D.P.; BARROS, F.C.; POST, C.L.A. et al. Prevalência de obesidade em adultos e seus fatores de risco. Revista de Saúde Pública, v.31, n.3, p.236-246, jun. 1997.

GONSALVES, P.E. Alimentação natural do bebê, da criança e do adolescente. São Paulo: ALMED, 1986. cap.11, p.61-86: Verduras e hortaliças.

GOUVEIA, E.L.C. Nutrição, saúde \& comunidade. Rio de Janeiro: Revinter, 1999. 247p.

GUERRA, V.M.C.O. (Coord.). Primeiro censo estadual de altura/idade dos escolares de primeira série do ensino fundamental do estado do Ceará. Fortaleza: Secretaria da Educação do Estado do Ceará, 1993. 60p.

INSTITUTO BRASILEIRO DE GEOGRAFIA E ESTATÍSTICA. Desenvolvimento Humano e condições de vida: indicadores brasileiros (compact disc). Brasília: PNUD/ IPEA/FJP, 1998. 
INSTITUTO BRASILEIRO DE GEOGRAFIA E ESTATÍSTICA. Censo 2000. http://www.ibge.gov.br (9 maio 2002)

INSTITUTO SODEXHO PARA O DESENVOLVIMENTO DA QUALIDADE DE VIDA NO COTIDIANO. Masculino e feminino: os diferentes hábitos alimentares entre crianças e jovens. São Paulo: Sodexho Alliance, 2001. $29 p$.

JUNQUEIRA, A.H.; LUENGO, R.F.A. Mercados diferenciados de hortaliças. Circular Técnica EMBRAPA, n.17, p.1-7, 1999.

JUNQUEIRA, A.H.; PEETZ, M.S. Fome oculta. Agroanalysis, v.21, n.8, p.8-12, ago. 2001.

KAZAPI, I.M.; DI PIETRO, P.F.; AVANCINI, S.R.P. et al. Consumo de energia e macronutrientes por adolescentes de escolas públicas e privadas. Revista de Nutrição, v.14, p.27-33, 2001. Suplemento.

KEYS, A. Coronary heart disease in seven countries. Circulation, v.41, n.1, p.11-211, 1970.

LERNER, B.R. A alimentação e anemia carencial em adolescentes. São Paulo, 1994. 90p. Tese (Doutorado) - Faculdade de Saúde Pública, Universidade de São Paulo.

LIMA, E.S.; EUCLYDES, M.P.; CRUZ, T.A. et al. Condições socioeconômicas, alimentação e nutrição da população urbana de uma localidade do estado de Minas Gerais. Revista de Saúde Pública, v.23, n.5, p.410-421, 1989. 
LOPES, E.C.F., DERIVI, S.C.N., MENDEZ, M.H.M. The relation between cancer of the colon and rectum and nutrition. Archivos Latinoamericanos de Nutricion, v.34, n.2, p.282-287, 1986.

MAHAN, L.K.; ARLIN, M.T. Krause: alimentos, nutrição e dietoterapia. 8.ed. São Paulo: Roca, 1995. 957p.

MAHAN, L.K.; ESCOTT-STUMP, S. Krause: alimentos, nutrição e dietoterapia. 9.ed. São Paulo: Roca, 1998. 1179p.

MAISTRO, L.C. Alface minimamente processada: uma revisão. Revista de Nutrição, v.14, n.3, p.219-224, set./dez. 2001.

MANTEL, N.; HAENSZEL, W. Statistical aspects of analysis of data from retrospective studies of disease. Journal of The National Cancer Institute, v.22, p.719-748, 1959.

MEILGAARD, M.; CIVILLE, G.V.; CARR, B.T. Sensory evaluation techniques. Boca Raton: CRC Press, 1990. 281p.

MENDES, F.S.V.; PRIORE, S.E.; RIBEIRO, S.M.R. et al. Avaliação do estilo de vida e condições nutricionais de adolescentes atendidos em um programa específico. Nutrição em Pauta, v.9, n.47, p.20-24, mar./abr. 2001.

MONDINI, L.; MONTEIRO, C.A. Mudanças no padrão de alimentação da população urbana brasileira (1962 - 1988). Revista de Saúde Pública, v.28, n.6, p.433-494, 1994. 
MONTEIRO, C.A. Saúde e nutrição das crianças de São Paulo: diagnóstico, contrastes sociais e tendências. São Paulo: HUCITEC/EDUSP, 1988. $165 p$.

MONTEIRO, C.A.; CONDE, W.L. Tendência secular da desnutrição e da obesidade na infância na cidade de São Paulo (1974-1996). Revista de Saúde Pública, v.34, n.6, p.53-61, 2000.

MONTEIRO, C.A.; MONDINI, L.; COSTA, R.B.L. Mudanças na composição e adequação nutricional da dieta familiar nas áreas metropolitanas do Brasil (1988 - 1996). Revista de Saúde Pública, v.34, n.3, p.251-258, jun. 2000.

MORAIS, M.B.; VÍTOLO, M.R.; AGUIRRE, A.N.C. et al. Teor de fibra alimentar e de outros nutrientes na dieta de crianças com e sem constipação intestinal crônica funcional. Arquivos de Gastroenterologia, v.33, n.2, p.93-101, 1996.

MOURA, E.C.; SONATI, J.G. Perfil lipídico de dietas e sua relação com os níveis de colesterolemia em escolares de uma escola pública de Campinas, São Paulo (Brasil). Revista de Nutrição, v.11, n.1, p.69-75, 1998.

NATIONAL ACADEMY OF SCIENCES. Institute of Medicine. Food and Nutrition Board. Dietary reference intakes. Washington: National Academy Press, 2000.

NATIONAL ACADEMY OF SCIENCES. Institute of Medicine. Food and Nutrition Board. Dietary reference intakes: energy, carbohydrate, fiber, fat, fatty acids, cholesterol, protein and amino acids. Washington: National Academy Press, 2002. cap.11, p.609-696: Macronutrients and healthful diets. http//www.nap.edu (20 Sep. 2002) 
NATIONAL CENTER FOR HEALTH STATISTICS. Center for Disease Control and Prevention. Growth Charts. http://www.cdc.gov (14 Aug. 2002)

NATIONAL RESEARCH COUNCIL. National Academy of Sciences. Food and Nutrition Board. Recommended dietary allowances. 10.ed. Washington: National Academy Press, 1989.

NESS, A.R.; POWLES, J.W. Fruit and vegetables: cardiovascular disease. International Journal of Epidemiology, v.26, n.1, p.1-13, 1997.

NGUYEN-THE, C.; CALIN, F. The microbiology of minimally processed fresh fruits and vegetables. Critical Reviews in Food Science and Nutrition, v.34, n.4, p.371-401, 1994.

NOBRE, F.; FURTADO, M.R. O tratamento da hipertensão arterial. Revista da Associação Médica Brasileira, v.40, n.4, p.247-261, 1994.

OLIVEIRA, S.P.; THÉBAUD-MONY, A. Modelo de consumo agro-industrial: homogeneização ou diversificação dos hábitos alimentares. Cadernos de Debate, v.4, p.1-13, 1996.

OLIVEIRA, J. O papel da merenda na alimentação diária dos ingressantes no primeiro grau das escolas municipais de São Paulo. São Paulo, 1997. 132p. Dissertação (Mestrado) - Faculdade de Gências Farmacêuticas, Universidade de São Paulo. 
OLIVEIRA, J.; PHILIPPI, S.T.; CYRILLO, D.C. et al. A alimentação de escolares no município de São Paulo. In: CONGRESSO BRASILEIRO DE CIÊNCIA E TECNOLOGIA DE ALIMENTOS, 16., Rio de Janeiro, 1998. Alimentos, população e desenvolvimento. Rio de Janeiro: SBCTA, 1998. p.495-498.

PENNA, E.W. Métodos sensoriales y sus aplicaciones. In: ALMEIDA, T.C.A.; HOUGH, G.; DAMÁSIO, M.H. et al. Avanços em análise sensorial. São Paulo: Varela, 1999. cap.1, p.13-22: Métodos sensoriales y sus aplicaciones.

PHILIPPI, S.T.; SZARFARC, S.C.; LATTERZA, A.R. Virtual Nutri (software). Versão 1.0 for Windows. São Paulo: Universidade de São Paulo, Faculdade de Saúde Pública, Departamento de Nutrição, 1996.

PHILIPPI, S.T.; COLUCCI, A.C.A.; CRUZ, A.T.R. et al. Alimentação saudável na infância e adolescência. In: SILVA, M.V.; PIPITONE, M.A.P.; STURION, G.L. et al. Curso de atualização em alimentos e nutrição para professores da rede pública de ensino. Piracicaba: ESALQ/USP, 2000. p.46-60.

PILON, L.; FIGUEIREDO, M.; OETTERER, M. et al. Diretrizes para implantação de agroindústria para processamento mínimo de hortaliças: cenoura e pimentão (compact disc). In: CONGRESSO BRASILEIRO DE CIÊNCIA E TECNOLOGIA DE ALIMENTOS, 18., Porto Alegre, 2002. Anais. Porto Alegre: SBCTA, 2002a. 
PILON, L.; OETTERER, M.; SILVA, M.V. et al. Otimização do processamento mínimo de cenouras visando manutenção dos nutrientes (compact disc). In: CONGRESSO BRASILEIRO DE CIÊNCIA E TECNOLOGIA DE ALIMENTOS, 18., Porto Alegre, 2002. Anais. Porto Alegre: SBCTA, 2002b.

PROBIÓTICOS: a chave dos funcionais. USDEC News, v.5, n.1, set. 2002.

RABELLO, T. Processamento mínimo, lucro máximo. Frutas \& Legumes, v.1, n.1, p.13-20, set./out. 1999.

RIBEIRO, L.C.; DEVINCENZI, M.U.; VIANA, E.C. et al. Ácido fólico: sua importância em situações fisiológicas do ciclo vital. Compacta Nutrição, v.3, n.1, p.7-18, abr. 2002.

ROJAS, R.M. Fruits and vegetables consumption among Costa Rican adolescents. Archivos Latinoamericanos de Nutrición, v.51, n.1, p.8185, Mar. 2001.

ROOS, E.B.; HIRVONEN, T.; MIKKILÄ, V. et al. Household educational level as a determinant of consumption of raw vegetables among male and female adolescents. Preventive Medicine, v.33, n.4, p.282-291, Oct. 2001.

SALAY, E.; CARVALHO, J.F. Avaliação do programa de merenda escolar do município de Campinas, Brasil. Archivos Latinoamericanos de Nutrición, v.45, n.3, p.167-171, jun. 1995.

SALAZAR, A.M.J. Perfil biológico, ambiental e comportamental de uma população infantil obesa. São Paulo, 1996. 74p. Dissertação (Mestrado) Faculdade de Saúde Pública, Universidade de São Paulo. 
SALES, A.M. Perdas nutricionais em alimentos. Campinas: ITAL, 1988. p.105.

SAMPAIO, M.F.A. Análise comparativa do consumo de alimentos: América Latina e União Européia. Campinas, 2001. 74p. Dissertação (Mestrado) Faculdade de Engenharia Agrícola, Universidade Estadual de Campinas.

SAMUELSON, G.; BRATTEBY, L.E.; BERGGREM, K. et al. Dietary iron intake and iron status in adolescents. Acta Paediatr, v.85, n.9, p.1033-1038, Sep. 1996.

SANT'ANA, A.; AZEVEDO, D.P.; COSTA, M. et al. Análise de perigos no processamento mínimo de vegetais. Revista Higiene Alimentar, v.16, n.101, p.80-84, out. 2002.

SARANTÓPOULOS, C.I.G.L.; OLIVEIRA, L.M.; CANAVESI, E. Requisitos de conservação de alimentos em embalagens flexíveis. Campinas: CETEA/ITAL, 2001. 215p

SAS INSTITUTE. The SAS System (software). Versão 8. Cary, 1998.

SASAKI, F.F.; MAESTRO, V.; SANCHES, M. et al. Análise das preferências de escolares, da rede pública de ensino, por hortaliças minimamente processadas. /Apresentado ao 9. Simpósio Internacional de Iniciação Científica da USP, Piracicaba, 2001/

SHIMPTOM, R. Food consumption and dietary adequacy according to income in 1200 families, Manaus, Amazonas, Brasil. Archivos Latinoamericanos de Nutrición, v.34, n.4, p.615-629, 1984. 
SICHIERI, R. Epidemiologia da obesidade. Rio de Janeiro: UERJ, 1998. $140 p$.

SILVA, M.V. Estado nutricional de escolares matriculados em Centros Integrados de Educação Pública - CIEP's. São Paulo, 1996. 103p. Tese (Doutorado) - Faculdade de Saúde Pública, Universidade de São Paulo.

SILVA, M.V. Alimentação na escola como forma de atender æ̀ recomendações nutricionais de alunos dos Centros Integrados de Educação Pública (CIEPS). Cadernos de Saúde Pública, v.14, n.1, p.171-180, jan./mar. 1998a.

SILVA, M.V. Mudanças dos hábitos alimentares da população brasileira. Alimentação \& Nutrição,v.18, n.71, p.40-49, 1998b.

SILVA, M.V.; PIPITONE, M.A.P.; STURION, G.L. et al. Educação e saúde e sua relação com o estado nutricional e práticas alimentares de escolares de 1ำ grau. In: CONGRESSO BRASILEIRO DE CIÊNCIA E TECNOLOGIA DE ALIMENTOS, Rio de Janeiro, 1998. Anais. Rio de Janeiro: SBCTA, 1998. p.616-619.

SILVA, M.V.; FERRATORE, V.A.; TEREZANI, O.L. Avaliação antropométrica de escolares. Saúde em Revista, v.1, n.2, p.43-51, jul./dez. 1999a.

SILVA, M.V.; OETTERER, M.; STURION, G.L. Programa de apoio à agroindústria, abastecimento e alimentação no município de Piedade, São Paulo. Piracicaba: ESALQ, Depto. de Agroindústria, Alimentos e Nutrição/FAPESP, 1999b. 13p. 
SILVA, M.V. Alimentos consumidos pelos alunos de escolas de tempo integral. Alimentação e Nutrição, v.11, p.89-110, 2000.

SKURA, B.J.; POWRIE, W.D. Modified atmosphere packing of fruits and vegetables. New York: VCH Publishers, 1995. 279p.

STURION, G.L. Programa de alimentação escolar: avaliação do desempenho em dez municípios brasileiros. Campinas, 2002. 269p. Tese (Doutorado) Faculdade de Engenharia de Alimentos, Universidade Estadual de Campinas.

TEIXEIRA, E.; MEINERT, E.M.; BARBETTA, P.A. Análise sensorial de alimentos. Florianópolis: UFSC, 1987. 180p. (Série didática)

TSENG, M.; CHAKRABORTY, H.; ROBINSON, D.T. et al. Adjustment of iron intake for dietary enhancers and inhibitors in population studies: bioavailable iron in rural and urban residing russian women and children. The Journal of Nutrition, v.127, n.8, p.1456-1468, Aug.1997.

VANNUCCHI, H. (Coord.); MENEZES, E.W.; CAMPANA, A. et al. Aplicações das recomendações nutricionais adaptadas à população brasileira. Ribeirão Preto: SBAN, 1990. 156p. (Cadernos de Nutrição, 2)

VARELLA, F. Cardápio renovado. Veja, v.38, n.1492, p.46, abr. 1997.

VERRUMA, M. Análise sensorial de alimentos. s.l.: s.ed., 2000. 1v. 
VILLAR, B.S. Desenvolvimento e validação de um questionário semiquantitativo de freqüência alimentar para adolescentes. São Paulo, 2001. 133p. Tese (Doutorado) - Faculdade de Saúde Pública, Universidade de São Paulo.

WILLEY, R.C. Frutas y hortalizas minimamente procesadas y refrigeradas. Zaragoza: Acribia, 1997. 362p.

WORLD HEALTH ORGANIZATION - WHO. Physical status: the use and interpretation of anthropometry. Geneva, 1995. 452p. (Who Technical Report Series, 854)

ZARPELLON JÚNIOR, B.; TREVISAN, H.J. FOXBASE +: gerenciador de base de dados para DOS (software). Piracicaba: ESALQ, Centro de Informática na Agricultura, 1991. 